\title{
HENTEI-DAURIA FOLD SYSTEM OF THE MONGOLIA-OKHOTSK BELT: MAGMATISM, SEDIMENTOGENESIS, AND GEODYNAMICS
}

\author{
I. V. Gordienko', O. R. Minina1, L. I. Vetluzhskikh¹, \\ A. Ya. Medvedev², D. Odgerel ${ }^{3}$ \\ ${ }^{1}$ Geological Institute, Siberian Branch of RAS, Ulan-Ude, Russia \\ ${ }^{2}$ A.P. Vinogradov Institute of Geochemistry, Siberian Branch of RAS, Irkutsk, Russia \\ ${ }^{3}$ Institute of Paleontology and Geology of MAS, Ulaanbaatar, Mongolia
}

\begin{abstract}
The geostructural, petrological, geochemical, geochronological and biostratigraphic studies were conducted in the Hentei-Dauria fold system of the Mongolia-Okhotsk orogenic belt. This Paleozoic system is composed mainly of three heterochronous rock associations related to the onset and development of oceanic basins and active margins in the conjugation zone of the Siberian continent and the Mongolia-Okhotsk ocean. This region developed in three stages: (1) Late Caledonian (Ordovician - Early Silurian), (2) Early Hercynian (Late Silurian - Devonian), and (3) Late Hercynian (Carboniferous-Permian). In the Late Caledonian, oceanic seafloor spreading was initiated, deep-sea siliceous deposits were formed, basaltic and andesitic pillow lavas were erupted, and layered and cumulative gabbros, gabbro-dolerite dykes and subduction zones with island-arc magmatism were formed. After a short quiescence period, new zones of spreading and subduction occurred at the active margins of the Mongolia-Okhotsk ocean in the Early Hercynian. In the Late Hercynian, large back-arc sedimentary basins, accretionary prisms and connecting intraplate magmatic complexes were formed in all structures of the Hentei-Dauria fold system. As a result of our studies, we propose a comprehensive model showing the geodynamic development of the Hentei-Dauria fold system that occurred in the area of the Mongolia-Okhotsk Ocean and its margins.
\end{abstract}

Key words: Mongolia; Transbaikalia; oceanic basin; island-arc magmatism; Hentei-Dauria fold system; Siberian continent; Mongolia-Okhotsk ocean; geodynamic reconstruction

For citation: Gordienko I.V., Minina O.R., Vetluzhskikh L.I., Medvedev A.Ya., Odgerel D., 2018. Hentei-Dauria fold system of the MongoliaOkhotsk belt: magmatism, sedimentogenesis, and geodynamics. Geodynamics \& Tectonophysics 9 (3), 1063-1097. doi:10.5800/GT-2018-9-30384.

Для цитирования: Гордиенко И.В., Минина О.Р., Ветлужских Л.И., Медведев А.Я., Одгэрэл Д. Хэнтей-Даурская складчатая система Монголо-Охотского пояса (магматизм, седиментогенез, геодинамика) // Геодинамика и тектонофизика. 2018. Т. 9. № 3. С. 1063-1097. doi:10.5800/GT-2018-9-3-0384. 


\title{
ХЭНТЕЙ-ДАУРСКАЯ СКЛАДЧАТАЯ СИСТЕМА МОНГОЛО-ОХОТСКОГО ПОЯСА (МАГМАТИЗМ, СЕДИМЕНТОГЕНЕЗ, ГЕОДИНАМИКА)
}

\author{
И. В. Гордиенко ${ }^{1}$, О. Р. Минина ${ }^{1}$, Л. И. Ветлужских ${ }^{1}$, \\ А. Я. Медведев ${ }^{2}$, Д. Одгэрэл ${ }^{3}$ \\ ${ }^{1}$ Геологический институт СО РАН, Улан-Удэ, Россия \\ ${ }^{2}$ Институт геохимии им. А.П. Виноградова СО РАН, Иркутск, Россия \\ ${ }^{3}$ Институт палеонтологии и геологии Академии наук Монголии, Улан-Батор, Монголия
}

\begin{abstract}
Аннотация: В результате проведенных структурно-геологических, петролого-геохимических, геохронологических и биостратиграфических исследований установлено, что палеозойская Хэнтей-Даурская складчатая система Монголо-Охотского орогенного пояса сложена главным образом тремя разновозрастными ассоциациями пород, связанными с заложением и развитием океанических бассейнов и активных окраин в зоне сопряженного взаимодействия Сибирского континента и Монголо-Охотского океана в течение трех этапов: 1) позднекаледонского (ордовикско-раннесилурийского), во время которого произошло заложение океанического спредингового бассейна и формирование глубоководных кремнистых отложений, излияние пиллоу-лав базальтов и андезибазальтов, образование расслоенных и кумулятивных габбро, даек габбро-долеритов, а также зон субдукции с островодужным магматизмом, 2) раннегерцинского (позднесилурийско-девонского), когда после небольшого перерыва вновь произошло заложение новых зон спрединга и субдукции на активных окраинах Монголо-Охотского океана, и 3) позднегерцинского (каменноугольно-пермского), завершившегося образованием крупных задуговых осадочных бассейнов, формированием аккреционных призм и сшивающих внутриплитных магматических комплексов во всех структурах Хэнтей-Даурской складчатой системы. На основе полученных данных разработана комплексная модель геодинамического развития Хэнтей-Даурской складчатой системы, сформированной на месте Монголо-Охотского океана и его окраин.
\end{abstract}

Ключевые слова: Монголия; Забайкалье; океанический бассейн; островодужный магматизм; ХэнтейДаурская складчатая система; Сибирский континент; Монголо-Охотский океан; геодинамические реконструкции

\section{1. ВВЕДЕНИЕ}

При тектоническом районировании территории Монголии и смежных районов Забайкалья выделяется крупная Хангай-Хэнтей-Даурская система палеозойских прогибов и окружающих их поднятий, которая занимает ключевое положение в геологическом строении Монголо-Забайкальского региона. В современной структуре Хэнтей-Даурская система состоит из цепочки изолированных осадочных прогибов, окаймленных краевыми и поперечными поднятиями, разбитыми разломами разных направлений на отдельные блоки, которые пронизаны многочисленными магматическими телами разного размера и возраста. Складчатая структура блоков характеризуется резкими изменениями простираний складчатых деформаций. Преобладающим простиранием складчатых структур в Хэнтей-Даурской системе прогибов является северовосточное направление. Несмотря на длительную историю изучения структур Хэнтей-Даурской системы, их природа до сих пор остается предметом дискуссий. До появления новой глобальной текто- ники, или тектоники литосферных плит, эти структуры назывались регенерированными геосинклинальными прогибами или моногеосинклиналями [Marinov, 1973b; Yanshin, 1974]. В последующем, с появлением мобилистских реконструкций и террейнового анализа возникли новые представления о связи этих структур с развитием ЦентральноАзиатского (ЦАСП) и Монголо-Охотского (МОСП) складчатых поясов, которые сформировались на месте соответственно Палеоазиатского и МонголоОхотского океанов и их окраин [Peive et al., 1976; Dobretsov, 1981; Gordienko, 1987; Zonenshain et al., 1976, 1990; u $\partial p$.].

В настоящее время существует несколько вариантов тектонического районирования МонголоОхотского складчатого пояса, которые различаются как в деталях внутреннего строения, так и по положению внешних границ пояса [Amantov, 1975; Kuzmin, Filippova, 1979; Zonenshain et al., 1990; Şengör et al., 1993; Gordienko, 1994, 1996; Belichenko et al., 1994; Gusev, Khain, 1995; Zorin et al., 1998, 2009; Parfenov et al., 1999; Khanchuk, 2006; Khanchuk et al., 2015; Gordienko, Metelkin, 2016; Gordienko et al., 2017]. 
В рамках нашей интерпретации складчатые структуры пояса по широкой полосе сближенных левосторонних сдвигов, объединяемых в МонголоОхотский линеамент (МОЛ), на севере контактируют с выступами фундамента Сибирской платформы и Саяно-Байкальским коллажем разновозрастных структур (байкалид, каледонид и герцинид), причлененных к кратону в течение неопротерозоя и палеозоя. На юге пояс вдоль Главного Монгольского линеамента (ГМЛ) обрамляется поясом преимущественно герцинских океанических и островодужных террейнов. Выделенные террейны внутри МОСП образуют вытянутые на сотни километров разновозрастные «лентовидные» структуры северо-восточного простирания, ограниченные системами разломов различных генетических типов (рис. 1).

Исходя из многолетнего опыта наших работ, в основном в центральной части МОСП на территории Монголии и Забайкалья, а также ввиду того, что значительная часть изученных террейнов находится на территории Монголии, мы придерживаемся названий террейнов, данных в работах [Badarch et al., 2002; Tomurtogoo, 2005, 2014; Bulgatov, Gordienko, 2014; Gordienko, 2014; и др.], и выделяем в западной части МОСП следующие террейны с запада на восток: Хангайский, Центрально-Монгольский (Хархоринский), Хэнтей-Даурский, Агинский и Аргунский.

Нашими исследованиями была охвачена площадь Хэнтей-Даурского сводово-глыбового поднятия, где на геологических картах Северной и Восточной Монголии, а также Восточного Забайкалья выделяется протяженная полоса палеозойских террейнов различной геодинамической природы, входящих в состав Монголо-Охотского складчатого пояса [Yanshin, 1989; Rutshtein, Starchenko, 1979] (рис. 1). Эта крупная палеозойская структура названа Хэнтей-Даурской складчатой системой, входящей в состав МОСП [Gordienko, 1987; Tomurtogoo, 2005, 2014; Gordienko et al., 2012b, 2017; Ruppen et al., 2014]. В соответствии с плитотектоническим анализом в ней выделяются океанические, преддуговые, задуговые, островодужные, аккреционные и коллизионные комплексы раннего, среднего и позднего палеозоя.

Задачей наших многолетних исследований Хэнтей-Даурской складчатой системы являлась разработка новой модели ее геодинамического развития на основе комплексного анализа с использованием структурно-геологических, петролого-геохимических, геохронологических и биостратиграфических данных по осадконакоплению, магматизму и тектонике в Монголо-Охотском складчатом поясе. Решению этой задачи посвящена данная статья.

\section{2. СТРУКТУРНО-ФОРМАЦИОННОЕ РАЙОНИРОВАНИЕ ХЭНТЕЙ-ДАУРСКОЙ СКЛАДЧАТОЙ СИСТЕМЫ}

Хэнтей-Даурская система расположена на северо-западном окончании МОСП и охватывает территорию собственно Хэнтей-Даурского и Агинского террейнов (рис. 1, 2). Структура системы вытянута в северо-восточном направлении на расстояние 600 км, при ширине 350-400 км, от Хархоринского поперечного поднятия северо-западного простирания, отделяющего Хэнтей-Даурскую систему от Хангайского террейна, до Даурского поднятия Центрального Забайкалья. Хэнтей-Даурская система контролируется северо-восточными глубинными разломами - структурными швами взбросо-сдвигового и надвигового типа, которые разбивают структуру на шесть близкоодновременных структурно-формационных зон (СФЗ) различной геодинамической природы: 1) каледонскую окраину Сибирского палеоконтинента (Центрально-Монгольский микроконтинент); 2) ордовик-силур-девонскую островодужную систему; 3) ордовик-силурийский спрединговый бассейн; 4) девонскую систему океанического и островодужного осадконакопления и магматизма; 5) каменноугольные перекрывающие и сшивающие осадочные, магматические комплексы Улан-Баторского и Даурского бассейнов в пределах центральной части Хэнтей-Даурской системы; 6) каледонскую окраину составного Идэрмэг-Эрэндава-Керуленского микроконтинента (рис. 2).

\section{1. СТРУКТУРНО-ФОРМАЦИОННЫЕ ЗОНЫ ХЭНТЕЙ-ДАУРСКОЙ СКЛАДЧАТОЙ СИСТЕМЫ}

При тектоническом районировании нами в пределах Хэнтей-Даурской системы выделены СФЗ, которые представляют крупные тектонические структуры, сложенные структурно-вещественными комплексами различной геодинамической природы (рис. 2). В террейновом анализе они в определенной мере соответствуют тектоностратиграфическим террейнам двух типов: террейнам А-типа террейнам аккреционного клина, сложенным в основном турбидитами, и В-типа - террейнам аккреционного клина, сложенным в основном океаническими комплексами [Nokleberg et al., 1994; Parfenov et al., 1998]. Однако террейновая интерпретация СФЗ слишком упрощенная. Она отсутствует на изданной недавно (2014г.) Международной тектонической карте Северной, Центральной и Восточной Азии и сопредельных территорий масштаба 1:2500000 [Petrov et al., 2014].

Выделенные нами СФЗ, сложенные структурновещественными комплексами, по своему составу и генезису были более разнообразны, что логично 


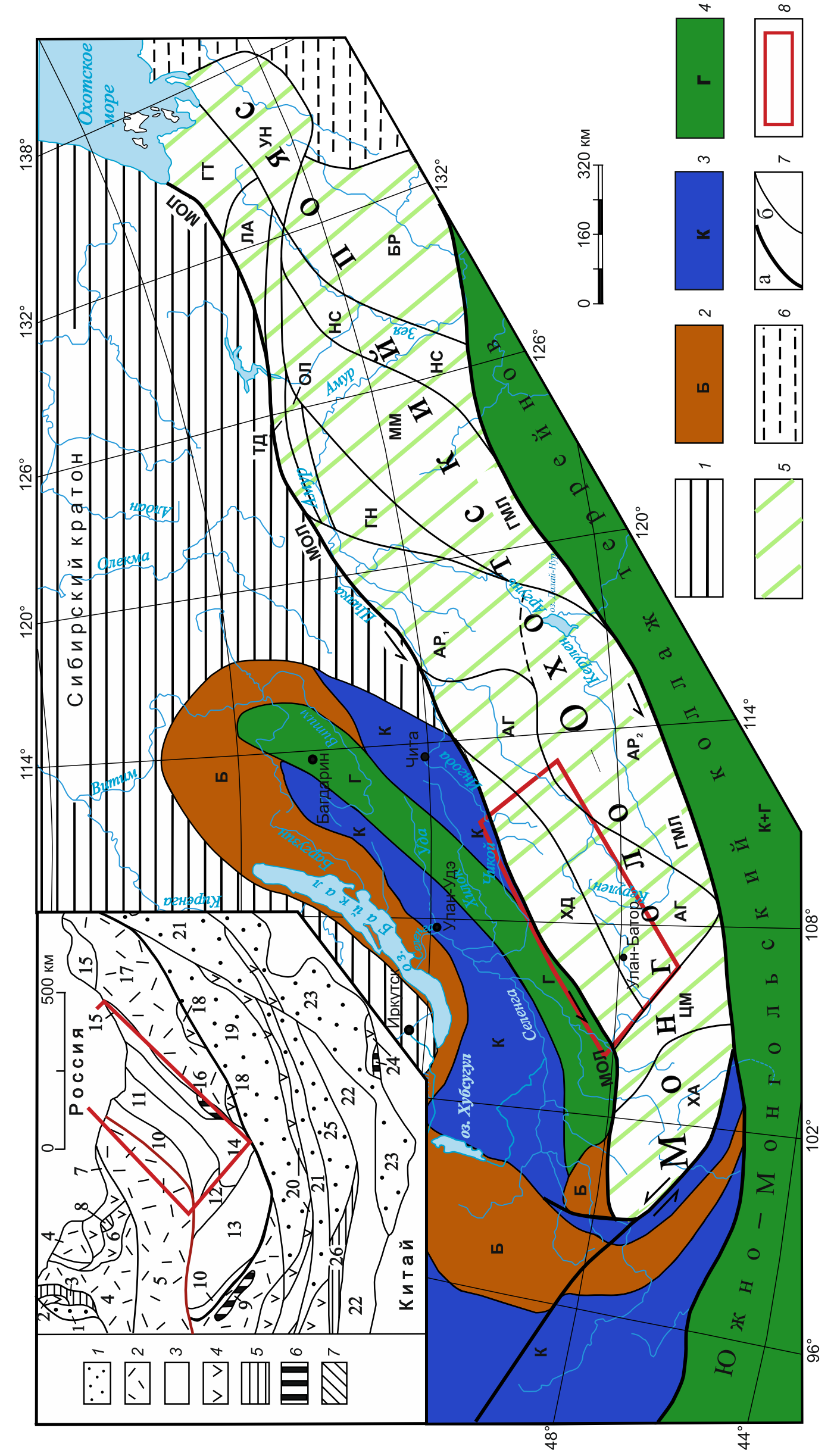




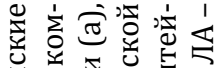
중 政

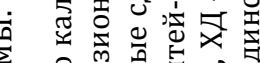

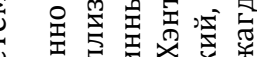
잉

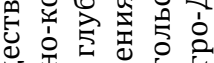
군 일 它 뜽 m $\pi$ 은 空 之要

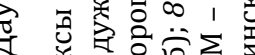

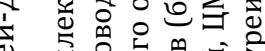
不

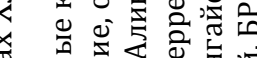

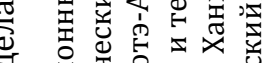

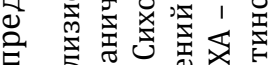
응

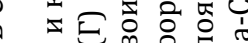
\% 不

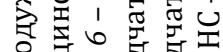

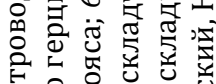

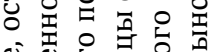
s.

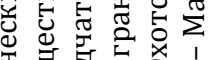

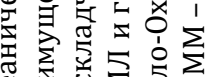
잉 o 10

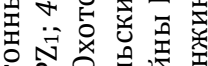
ㄴ.

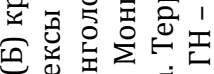

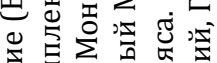

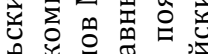
年, 尊

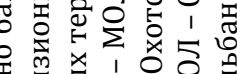

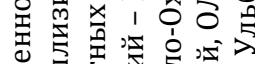
证 응 त.

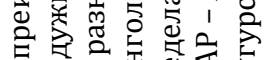
1 尊

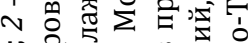
站 등

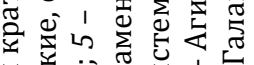
语 인 음

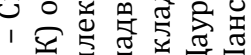

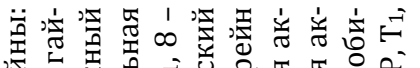

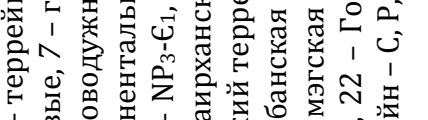

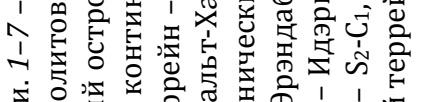

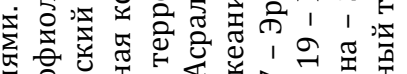

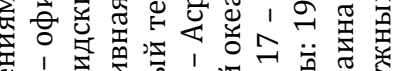

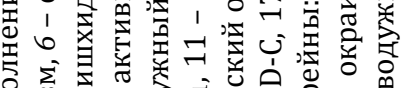

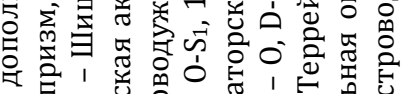

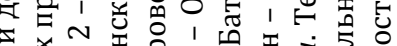

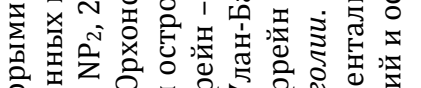
인

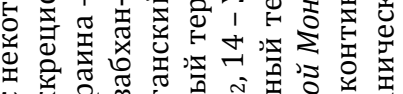

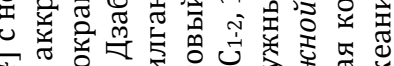
F

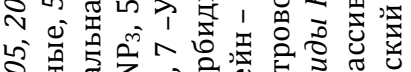

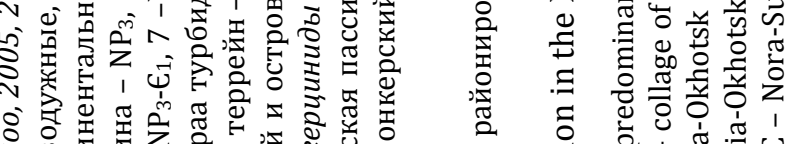

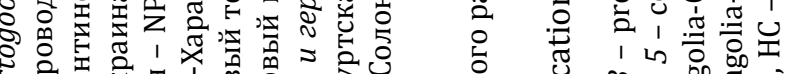

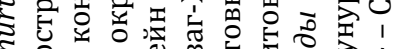

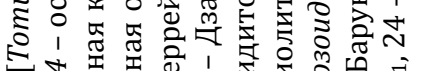

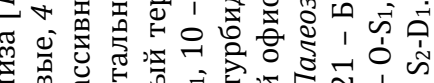

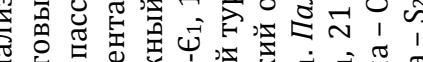

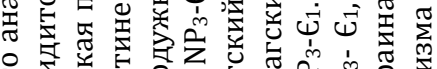

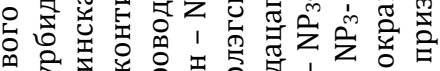

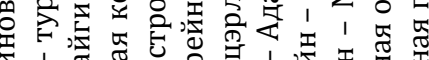

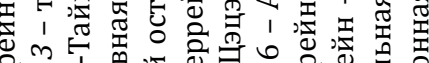

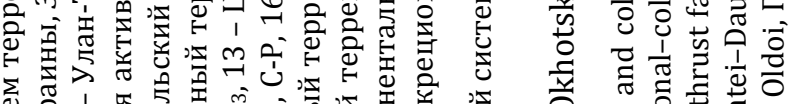

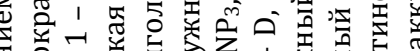

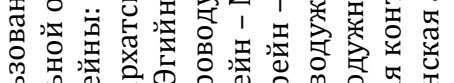
㲾

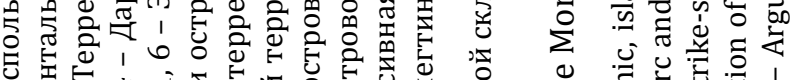

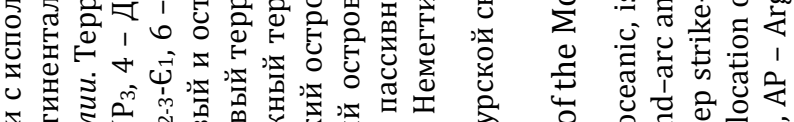

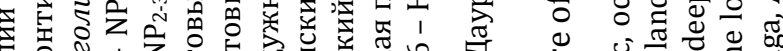

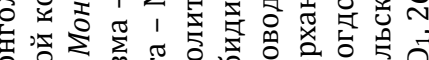

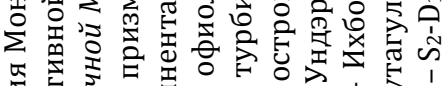

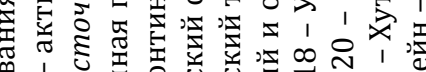

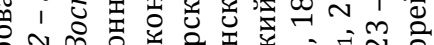

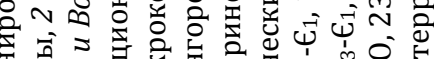

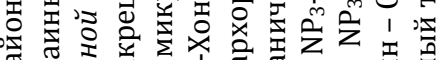

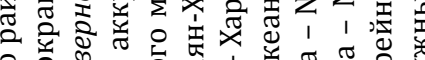

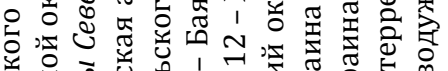

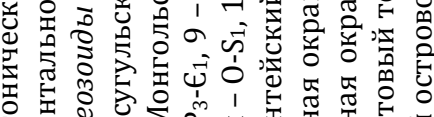

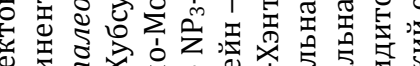

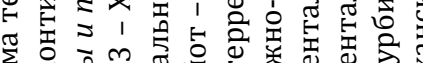

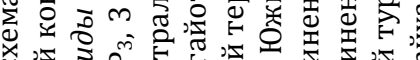

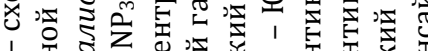

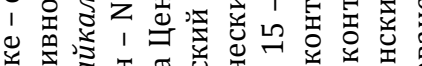

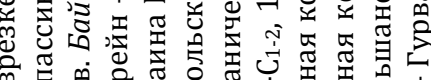

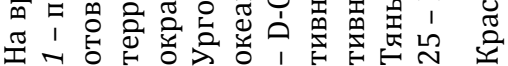

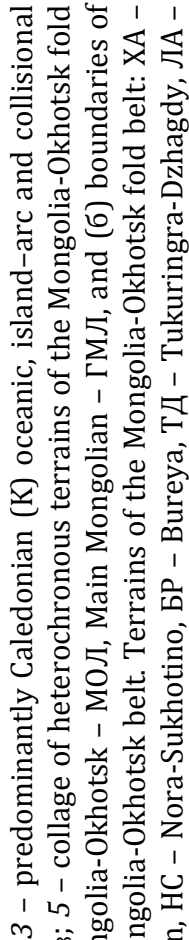

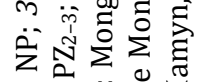

1, ij

ช.

응

就

주 뚷흉ㅎㅎ

을 흔

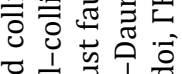

둥

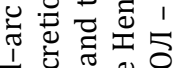

1

过

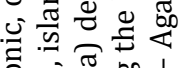

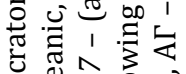

0

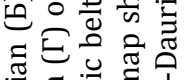

政.

两

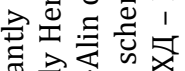

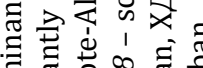

施

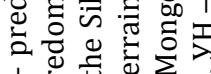

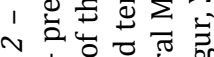

立枟完

可过边

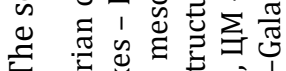

-

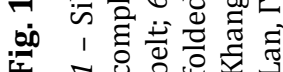

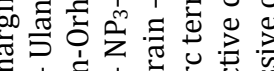

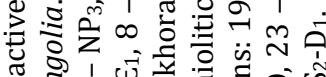

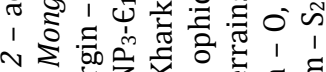
ह 든

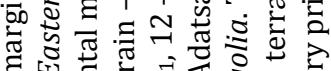

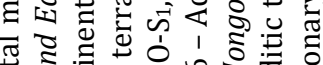
:

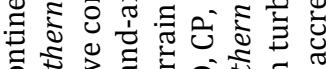

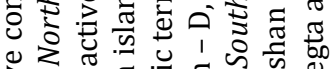

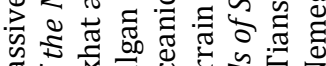

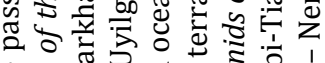

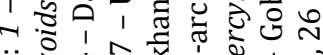

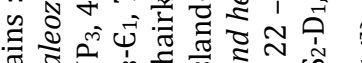
क्षे

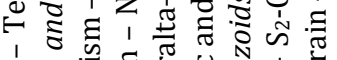

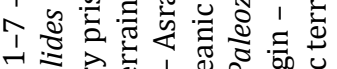
政

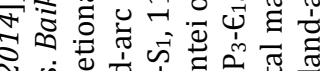
ง \&

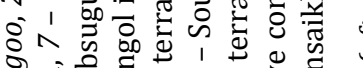

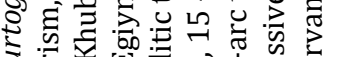

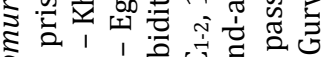

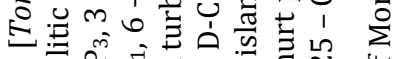

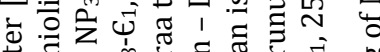

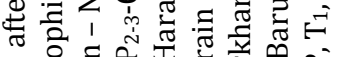
ठ

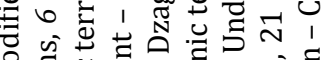

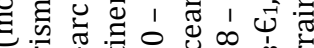
क 定

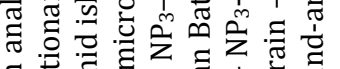

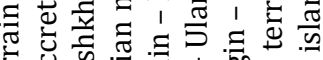

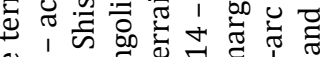
g is 1 过 过 б

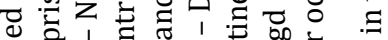

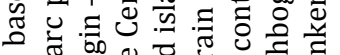

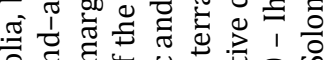
응 广

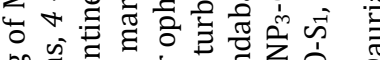
bo है

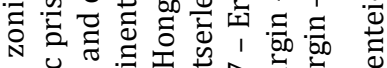

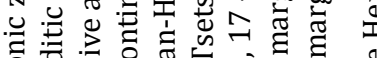

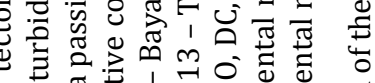

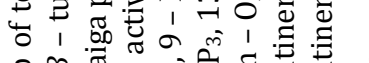

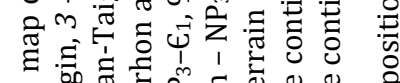

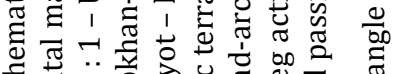

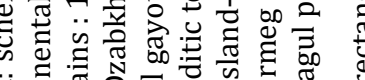

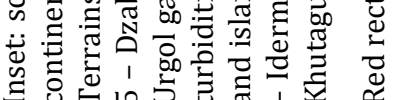




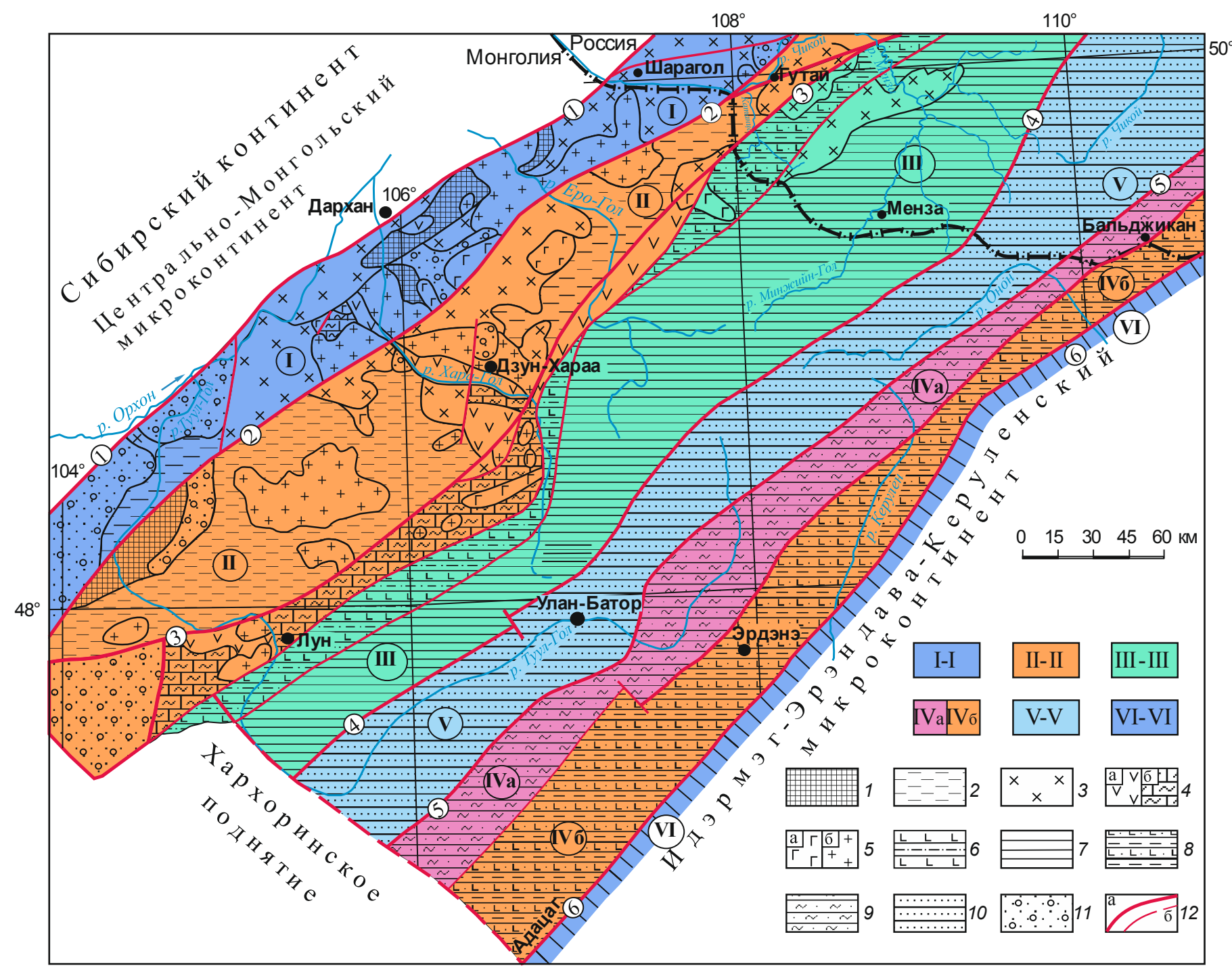

Рис. 2. Схема структурно-формационного районирования Хэнтей-Даурской складчатой системы. Составлена с использованием «Карты геологических формаций MHP» [Yanshin, 1989], «Геологической карты Читинской области» [Rutshtein, Starchenko, 1979] и материалов исследований авторов (см. список литературы).

Структурно-формационные зоны (римские цифры в цветных прямоугольниках): I-I - каледонская окраина Сибирского палеоконтинента (Центрально-Монгольский микроконтинент); II-II - Еро-Дзунмод-Лунская ордовик-силур-девонская островодужная система; III-III - Харагольский ордовик-силурийский спрединговый бассейн; IV-IV - Адацаг-Ононско-Агинская силурдевонская система океанического и островодужного осадконакопления и магматизма (а - Восточно-Хэнтейский океанический бассейн, б - Эрдэни-Адацагская островодужная система); V-V - девон-каменноугольные перекрывающие и сшивающие осадочные и магматические комплексы Улан-Баторского и Даурского бассейнов в пределах центральной части Хэнтей-Даурской системы; VI-VI - каледонская окраина Идэрмэг-Эрэндава-Керуленского составного микроконтинента.

Структурно-вещественные комплексы. Каледонская активная окраина Сибирского палеоконтинента: 1 - неопротерозойраннекембрийские нерасчлененные сланцево-терригенные, карбонатно-терригенные отложения; 2 - среднекембрийско-раннеордовикские песчано-сланцевые турбидитовые отложения; 3 - верхнекембрийско-раннеордовикские коллизионные и островодужные гранитоиды. Еро-Дзунмод-Лунской ордовик-силур-девонская островодужная система: 4 - вулканические ассоциации вулканотектонических структур (известково-щелочные базальты, андезиты, дациты, риолиты и их туфы) (а) и преддуговых и задуговых осадочных бассейнов (б); 5 - плутонические ассоциации: габбро, габбро-диориты, диориты, габбро-долериты (а); известково-щелочные граниты, граносиениты, гранодиориты, монцониты (б). Ордовик-силурийский океанический бассейн: 6 ордовикские океанические комплексы спрединговых зон (гемипелагические отложения, пиллоу-лавы базальтов, габбродолеритовые дайковые комплексы); 7 - ордовик-силурийские турбидитовые и флишоидные отложения в аккреционных призмах осадочного бассейна. Силур-девонская Адацаг-Ононско-Агинская система океанического и островодужного осадконакопления и магматизма: 8 - надсубдукционные офиолитовые (базит-гипербазитовые и кремнисто-базальтовые комплексы); 9 - гемипелагические отложения с базальтовыми лавами, радиоляриевыми яшмами, коралловыми известняками с силурдевонскими конодонтами в гайотах и аккреционных призмах преддугового бассейна. Перекрывающие осадочные бассейны и сшивающие магматические образования в аккреционных призмах Хэнтей-Даурской системы: 10 - карбоновые терригенные, сланцево-терригенно-карбонатные отложения в Улан-Баторском и Даурском осадочных бассейнах; 11 - ранне- и среднекарбоновые терригенно-молассовые отложения в Орхон-Шарынгольском и Чикойском наложенных прогибах. 12 - структурные швы 
(а) и другие разломы разных генетических типов (б). Структурные швы (цифры в кружочках): 1 - Орхон-Хилокский, 2 - БаянголЧикойский, 3 - Ерогол-Куналейский, 4 - Туулгол-Чикоконский, 5 - Восточно-Хэнтей-Даурский, 6 - Адацаг-Ононский.

На данной схеме не показаны послекарбоновые перекрывающие и сшивающие пермские, мезозойские и кайнозойские структурно-вещественные комплексы, имеющие площадное развитие в пределах всех СФЗ Хэнтей-Даурской складчатой системы.

Fig. 2. Schematic map of structure-formation zoning of the Hentei-Dauria fold system. Compiled using the Map of Geological Formations of the Mongolian People's Republic [Yanshin, 1989], Geological Map of the Chita Region [Rutshtein, Starchenko, 1979], and the database of the authors (see the list of references).

Structure-formation zones (Roman numerals in colored rectangles): I-I - Caledonian margin of the Siberian paleocontinent (Central Mongolian microcontinent); II-II - Ordovician-Silurian-Devonian Ero-Dzunmod-Lun island-arc system; III-III - Ordovician-Silurian Kharagol spreading basin; IV-IV - Silurian-Devonian Adatsag-Onon-Aga system of oceanic and island-arc sedimentation and magmatism (a East Hentei oceanic basin, 6 - Erdeni-Adatsag island-arc system); V-V - Devonian-Carboniferous overlying and connecting sedimentary and magmatic complexes of the Ulan-Bator and Dauria basins within the central part of the Hentei-Dauria system; VI-VI - Caledonian margin of the Idermeg-Erendava-Kerulen composite microcontinent.

Structure-formation complexes. Caledonian active margin of the Siberian paleocontinent: 1 - Neoproterozoic - Early Cambrian undivided shale-terrigenous, carbonate-terrigenous deposits; 2 - Middle Cambrian - Early Ordovician sand-shale turbiditic sediments; 3 - Upper Cambrian - Early Ordovician collisional and island-arc granitoids. Ordovician-Silurian-Devonian Ero-Dzunmod-Lun island-arc systems: 4 - volcanic associations of volcano-tectonic structures (calc-alkaline basalt, andesite, dacite, rhyolite and their tuffs) (a) and pre-arc and back-arc sedimentary basins (б); 5 - plutonic associations: gabbro, gabbro-diorite, diorite, gabbro-dolerite (a); calc-alkaline granite, granosyenite, granodiorite, monzonite (б). Ordovician-Silurian oceanic basin: 6 - Ordovician oceanic complexes of spreading zones (hemipelagic deposits, pillow lavas of basalt, gabbro-dolerite dyke complexes); 7 - Ordovician-Silurian turbiditic and flyschoid deposits in accretionary prisms of the sedimentary basin. Silurian-Devonian Adatsag-Onon-Aga system of oceanic and island-arc sedimentation and magmatism: 8 - suprasubduction ophiolite (basite-hyperbasite basalt and silica-basalt complexes); 9 - hemipelagic deposits with basaltic lavas, radiolarian jasper, coral limestone with Silurian-Devonian conodonts in guyots and accretionary prisms of the pre-arc basin. Overlying sedimentary basins and connecting magmatic formations in accretionary prisms of the Hentei-Dauria system: 10 - carbon terrigenous, shale-terrigenous-carbonate sediments in the Ulan-Bator and Dauria sedimentary basins; 11 - Early-Middle Carboniferous terrigenous-molasses deposits in the Orkhon-Sharyngol and Chikoi depressions. 12 - structural sutures (a) and other faults of different genetic types (б). Structural sutures (numbers in circles): 1 - Orkhon-Khilok, 2 - Bayangol-Chikoi, 3 - Erogol-Kunalei, 4 - Tuulgol-Chikokon, 5 East Hentei-Dauria, 6 - Adatsag-Onon.

This schematic map does not show post-carbon overlying and connecting Permian, Mesozoic and Cenozoic structural-material complexes observed in all structure-formation zones of the Hentei-Dauria fold system.

увязывается с историей плитотектонического развития исследованного региона.

\subsection{1. Каледонская активная окраина Сибирского палеоконтинента (Центрально-Монгольский микроконтинент)}

Данная структурно-формационная зона (СФЗ-I) соответствует фрагменту каледонской аккреционно-коллизионной зоны окраины Сибирского палеоконтинента. Она сложена мощными (до 5000 м) неопротерозой-нижнекембрийскими метаморфизованными сланцево-терригенными и карбонатнотерригенными комплексами с линзами кварцитов, метавулканитов, серпентинитов и габбро-пироксенитов с U-Pb возрастом 570-580 млн лет [Elbaev et al., 2017]. На них залегают среднекембрийско-раннеордовикские песчано-сланцевые турбидитовые отложения мандальской серии, прорванные позднекембрийско-раннеордовикскими островодужными гранитоидами малханского (472 2 млн лет) и боронурского $(467 \pm 3.8$ млн лет) комплексов Дзунмодской структуры, широко распространенными в пределах Центрально-Азиатского складчатого пояca [Voznesenskaya, 1998; Gordienko et al., 2012b; Altanzul et al., 2018]. В совокупности вся эта СФЗ представлена фрагментом каледонского ЦентральноМонгольского микроконтинента или массива Северо-Монгольской складчатой системы [Tomurtogoo, 2005, 2014].

\subsection{2. ХАРАГОЛЬСКИЙ СПРЕДИНГОВЫЙ БАССЕЙН}

Исследованная СФЗ-ІІІ занимает центральное место в Хэнтей-Даурской системе. Она с северозапада контролируется Ерогол-Куналейским глубинным разломом, а на юго-востоке перекрывается широкой полосой каменноугольных отложений, из-под которых в отдельных блоках Туулгол-Чикоконского и Восточно-Хэнтей-Даурского разломов вскрываются ордовик-силурийские породы харинской серии. В пределах Харагольской СФЗ в раннем-среднем ордовике (470-450 млн лет) началось формирование спредингового бассейна, сложенного глубоководными кремнистыми отложениями с яшмами, кварцитами, пиллоу-лавами базальтов и 
(a)

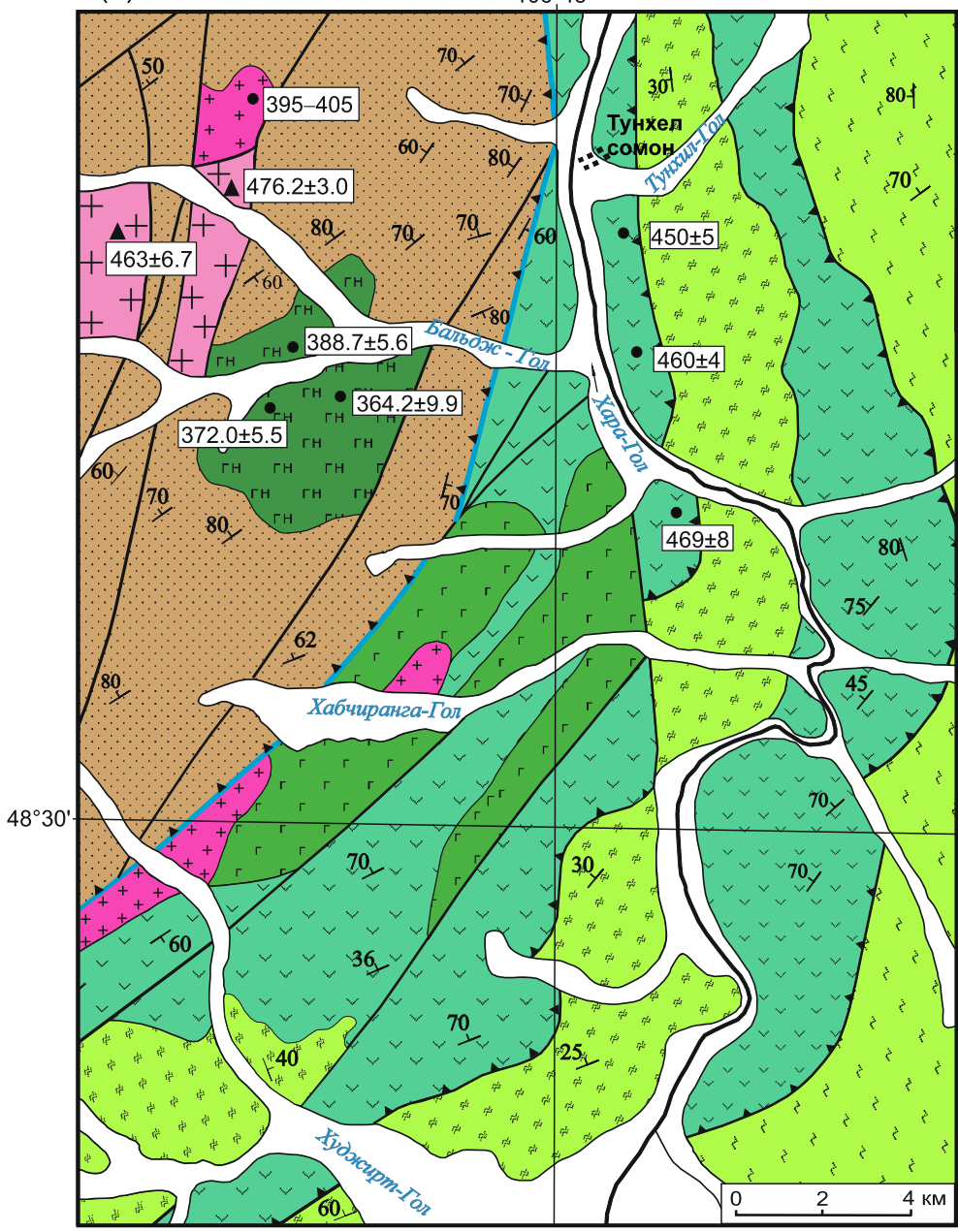

(б)

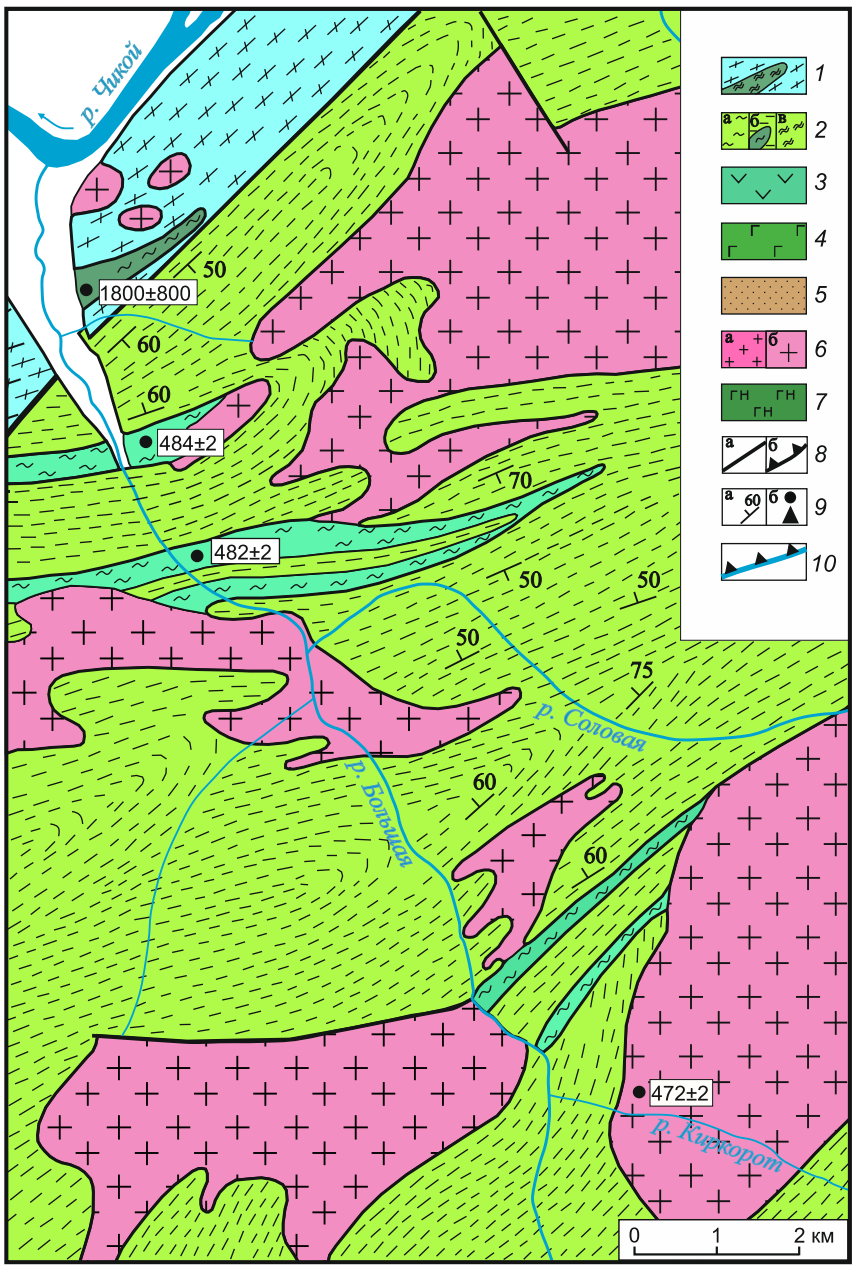

Рис. 3. Схема геологического строения Харагольского (Северная Монголия) (a) и Куналейского (Центральное Забайкалье) (б) бассейнов Хэнтей-Даурской АКО (по [Gordienko et al., 2012a, 2012b]).

1 - сланцево-гнейсовая толща с ортоамфиболитами неопротерозоя; 2 - турбидитовые отложения: а - флишоидная толща силура харинской серии; б - куналейская песчано-сланцевая толща с горизонтами метадолеритов $\left(0_{1,2}\right)$; в - туфогенно-кварцитопесчано-сланцевая толща $\left(\mathrm{O}_{2}-\mathrm{S}_{1}\right)$ харинской серии; 3 - толща гемипелагических кремнистых осадков, океанических базальтов с дайками габбро-диоритов и долеритов $\left(\mathrm{O}_{1,2}\right)$ харинской серии; 4 - кумулятивное и расслоенное габбро, габбро-пироксениты $\left(\mathrm{O}_{1,2}\right) ; 5$ - песчано-граувакковая толща $\left(\mathrm{D}_{2,3}\right) ; 6$ - гранитоиды: позднедевонские (a) и раннеордовикские (б); 7 - габброиды позднедевонские; 8 - разрывные нарушения: а - разломы; б - надвиги; 9 - элементы залегания (а) и точки определения абсолютного возраста, в млн лет (б): черные точки по данным авторов, черные треугольники по [Altanzul et al., 2018 ]; 10 - фронтальная граница ордовикских океанических и окраинно-континентальных комплексов (рис. $3, a$ ).

Fig. 3. Schematic map of the geological structure of the Kharagol (Northern Mongolia) (a) and Kunalei (Central Transbaikalia) (б) basins of the Hentei-Dauria active continental margin (after [Gordienko et al., 2012a, 2012b]).

1 - shale-gneiss stratum from Neoproterozoic orthoamphibolites; 2 - turbidite deposits: a - Silurian flyschoid stratum of the Kharin series; 6 - Kunalei sandy-shale sequence with metadolerite horizons $\left(0_{1,2}\right)$; в - tuffaceous-quartzite-sandy-shale sequence $\left(\mathrm{O}_{2}\right.$ - $\left.\mathrm{S}_{1}\right)$ of the Kharin series; 3 - stratum of hemipelagic siliceous sediments, oceanic basalts with dykes of gabbro-diorite and dolerite $\left(\mathrm{O}_{1,2}\right)$ of the Kharin series; 4 - cumulative and stratified gabbro, gabbro-pyroxenite $\left(\mathrm{O}_{1,2}\right) ; 5$ - sand-greywacke stratum $\left(\mathrm{D}_{2,3}\right) ; 6$ - granitoids: Late Devonian (a) and Early Ordovician (б); 7 - Late Devonian gabbroids; 8 - discontinuities: a - faults; 6 - thrusts; 9 - dip and strike (a) and dating points (absolute age, Ma) (б): black circles - the authors' data, black triangles - after [Altanzul et al., 2018]; 10 - frontal boundary of the Ordovician oceanic and continent-margin complexes (Fig. 3,a).

габбро-долеритовым дайковым комплексом. На океаническом основании в аккреционных призмах сформировались мощные (более 5 тыс. м) ордовиксилурийские турбидитовые и флишоидные отложения харинской серии, занимающие большие площади в Западном Хэнтее и Центральном Забайкалье (рис. 3).

Согласно нашим исследованиям [Gordienko et al., $2010,2012 b]$, в пределах Харагольского бассейна все выделенные в этом районе толщи мандальской 
$\left(\epsilon_{2}-\mathrm{O}_{1}\right)$ и харинской $\left(\mathrm{O}_{2}-\mathrm{S}_{1}\right)$ серии находятся в аллохтонном залегании, с крутыми углами падения в северо-западных румбах $\left(70-80^{\circ}\right)$, и надвинуты друг на друга. При этом вулканогенные породы низов харинской серии нижнего-среднего ордовика образуют здесь две полосы субмеридионального простирания по обоим бортам долины р. Хара-Гол. Они отделены друг от друга туфотурбидитовой (туфогенно-кварцито-песчано-сланцевой) толщей $\left(\mathrm{O}_{2}-\mathrm{S}_{1}\right)$, которая полого $\left(25-30^{\circ}\right)$ падает под толщу вулканитов, обнажающуюся в основном по левому борту долины р. Хара-Гол, по падям Худжирт-Гол, Хабчиранга-Гол, Бальдж-Гол.

В пределах этой полосы, представленной толщей подводных пиллоу-лав базальтов, гиалокластитов, кремнистых пород $\left(\mathrm{O}_{1-2}\right)$ и комагматичных этой толще габбро, габбро-пироксенитов с дайками габбро-долеритов и долеритов $\left(\mathrm{O}_{1-2}\right)$, обнажены также вытянутые вдоль северо-восточных разломов одновозрастные массивы габброидов (до 2-3 км в поперечнике) с многочисленными дайками габбро-долеритов и долеритов с U-Pb возрастом по цирконам и бадделеиту $(450 \pm 5,460 \pm 4,469 \pm 8$ млн лет) [Gordienko et al., 2012a, 2012b].

Аналогом мандальской $\left(\epsilon_{2}-\mathrm{O}_{1}\right)$ и харинской $\left(\mathrm{O}_{2}\right.$ $S_{1}$ ) серий на территории Центрального и Восточного Забайкалья Хэнтей-Даурской АКО могут быть значительно более метаморфизованные турбидитовые отложения Куналейского и Онон-Кулиндинского бассейнов (см. рис. 3 ; рис. 4).

В Куналейском бассейне, по рекам Большая и Куналей, распространены двуслюдяные, реже хлорит-серицитовые тонкослоистые, участками плойчатые сланцы и биотит-амфиболовые гнейсы с горизонтами и линзами метадолеритов. Характерной чертой являются четко выраженная слоистость, выдержанный состав пород. Мы полагаем, что исходными породами этих метаморфитов могла быть ассоциация, сходная с породами харинской серии. Это подтверждает близкий U-Pb возраст цирконов из двух проб метадолеритов - 484 2 и $482 \pm 2$ млн лет, соответственно. В низах разреза закартированы улелейская гнейсовая и катанцинская яшмоидная толщи, считавшиеся протерозойскими [Borisov, 1972]. Однако определенный нами U-Pb возраст цирконов из амфиболовых плагиогнейсов в устье р. Куналей свидетельствует о их раннеордовикском возрасте $-490 \pm 4$ млн лет, что позволяет соотнести их с Харагольским бассейном. Все отложения Куналейского бассейна интенсивно метаморфизованы в условиях зеленосланцевой фации метаморфизма, пронизаны интрузиями раннеордовикских $(472 \pm 2$ млн лет) гранитоидов [Gordienko et al., 2012a].

В Онон-Кулиндинском бассейне широко распространены метабазальты, объединяемые в составе кулиндинской и ононской свит (рис. 4). U-Pb дан- ные по цирконам метабазальтов показали конкор-

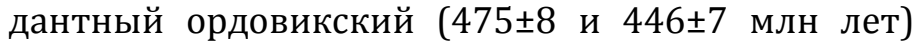
возраст [Bulgatov et al., 2010]. Важным геодинамическим индикатором является ордовик-силурийский Цугольский расслоенный габбро-плагиогранитный массив с U-Pb изотопным возрастом $448.2 \pm 9.1$ и $436 \pm 4$ млн лет $\left(\mathrm{O}_{3}-\mathrm{S}_{1}\right)$, указывающий на начало раскрытия Монголо-Охотского океана [Ruzhentsev, Nekrasov, 2009]. Все эти события хорошо увязываюся с развитием Харагольского спредингового бассейна Хэнтей-Даурской складчатой системы.

В последующем, по северо-западной и юго-восточной периферии Харагольского спредингового бассейна в раннем ордовике и силуре - раннем девоне возникли протяженные зоны субдукции, где на активных позднекаледонских окраинах Центрально-Монгольского и Идэрмэг-Эрэндава-Керуленского микроконтинентов сформировались островодужные системы (Еро-Дзунмод-Лунская и Адацаг-Ононско-Агинская).

\subsection{3. Еро-Дзунмод-Лунская ордовик-силур- девонская островодужная система}

Еро-Дзунмод-Лунская островодужная система (СФЗ-II) образовалась к северо-западу (в современных координатах) от спрединговой зоны Харагольского океанического бассейна, на Западно-Хэнтейской каледонской окраине Сибирского континента (см. рис. 2; рис. 5). В фундаменте в результате заложения Харагольского спредингового бассейна и последующей субдукции сформировались нижнесреднеордовикские риолиты, дациты, андезитовые порфириты уланундурской формации $(473.1 \pm 3.8$ и $475.2 \pm 6.1$ млн лет), а также многочисленные массивы ордовикских гранитоидов с абсолютным возрастом от $463.0 \pm 6.7$ до 471.4 \pm 2.7 млн лет [Altanzul et al., 2018]. Ордовикские вулканиты образуют цепочку выходов севернее Дзунмодской вулканотектонической структуры (ВТС), где они перекрываются терригенной толщей верхнего девона формации Ажнай [Minina et al., 2016a]. Ордовикские гранитоиды имеют более широкое распространение, охватывая каледонскую окраину Центрально-Монгольского микроконтинента и смежных островодужных структур Центрального Забайкалья.

Как установлено нами ранее [Gordienko, 1983, 1987], сформированные девонские вулканические постройки и преддуговые осадочные бассейны контролируются Ерогольским и Баянгольским крупными глубинными разломами, которые оконтуривают с северо-запада и юго-востока данную систему. Наиболее крупные ВТС сформировались вдоль Ерогольского разлома (Дзунмодская, Мунгуликская и Ялбаг-Ерогольская ВТС). На юго-западном окон- 


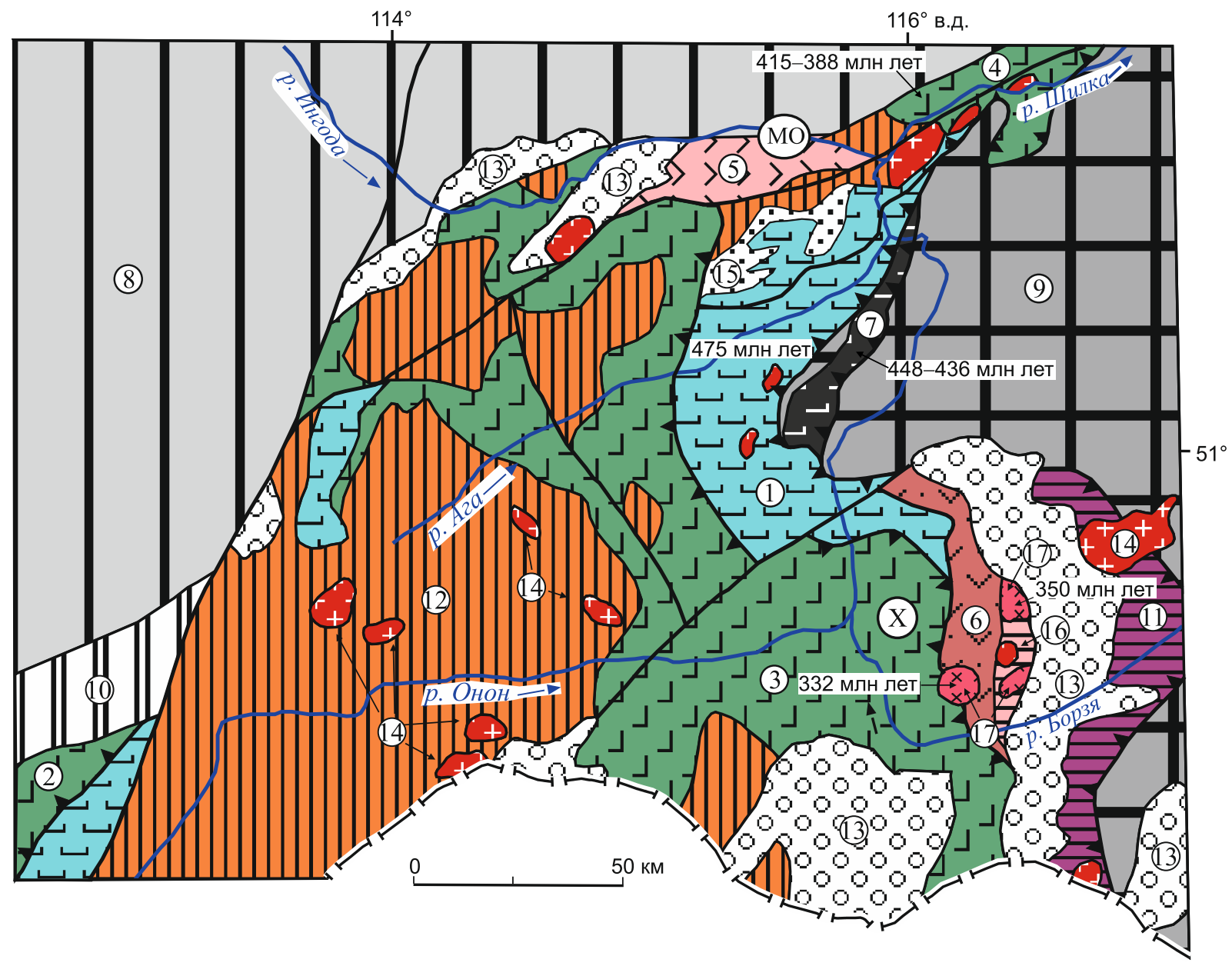

Рис. 4. Фрагменты островных дуг и океанической коры в Агинском террейне Монголо-Охотского пояса (по [Ruzhentsev, Nekrasov, 2009] с дополнениями).

Цифры и буквы в кружках: 1 - океаническая кора ордовикского возраста в Онон-Кулиндинском прогибе, 2 - океаническая кора ордовикского и девонского возраста в Агуца-Кыринском прогибе, 3 - девонская океаническая кора в Агинском прогибе, 4 - то же в Пришилкинском прогибе. Островные дуги - D3-С1: 5 - Береинская, 6 - Шерловогорская, 7 - Цугольский ордовик-силурийский габбро-плагиогранитный массив. 8 - Селенгино-Становой блок Сибирской платформы, 9 - Аргунский террейн, 10 - Хэнтей-Даурский террейн, 11 - Борзинский пермский прогиб, 12 - Могойтуйский триасовый прогиб, 13 - фрагменты юрско-мелового прогиба, 14 юрские граниты, 15 - Чиронский пермско-каменноугольный прогиб, 16 - серпентинитовый меланж, 17 - раннекаменноугольные гранитоиды, МO - Монголо-Охотский структурный шов, X - Харгинтуйская синформа. Приведены цифры U-Pb возраста пород в млн лет.

Fig. 4. Fragments of island arcs and ocean crust in the Aga terrain of the Mongolia-Okhotsk belt (modified after [Ruzhentsev, Nekrasov, 2009]).

Figures and letters in circles: 1 - Ordovician oceanic crust in the Onon-Kulinda trough, 2 - Ordovician and Devonian oceanic crust in the Agutsa-Kyra trough, 3 - Devonian oceanic crust in the Aga trough, 4 - Devonian oceanic crust in the Near-Shilka trough. Island arcs $\mathrm{D}_{3}-\mathrm{C}_{1}$ : 5 - Bereya, 6 - Sherlovaya Gora, 7 - Ordovician-Silurian Tsugol gabbro-plagiogranite massif. 8 - Selenga-Stanovoy block of the Siberian platform, 9 - Argun terrain, 10 - Hentei-Dauria terrain, 11 - Permian Borzya trough, 12 - Triassic Mogoitui trough, 13 - fragments of Jurassic-Cretaceous trough, 14 - Jurassic granite, 15 - Permian-Carbon Chiron trough, 16 - serpentinite melange, 17 - Early Carboniferous granitoid, MO - Mongolia-Okhotsk structural suture, $\mathrm{X}$ - Khargintui synform. Rock ages (Ma) according to the U-Pb dating.

чании Ерогольского разлома образовалась близкая по составу и возрасту Лунская ВТС. Формирование ВТС сопровождалось внедрением девонских интрузивных пород, которые охватывали по сравнению с вулканитами более широкую площадь как островодужной системы, так и активной окраины Центрально-Монгольского микроконтинента.

Дзунмодская ВТC расположена на левобережье p. Хара-Гол, в 15-20 км южнее ст. Дзун-Хара. Вулка- нический массив вскрыт на площади 230-240 км². Он имеет полукольцевую форму, обращенную выпуклостью на северо-запад, и на юго-востоке ограничен Ерогольским разломом. На севере также по разломам массив граничит с вулканогенными и терригенными толщами верхнего девона, сосредоточенными в небольших грабенах. В западной части породы массива круто $\left(60-85^{\circ}\right)$ наклонены на запад и северо-запад под толщу среднекембрийско- 


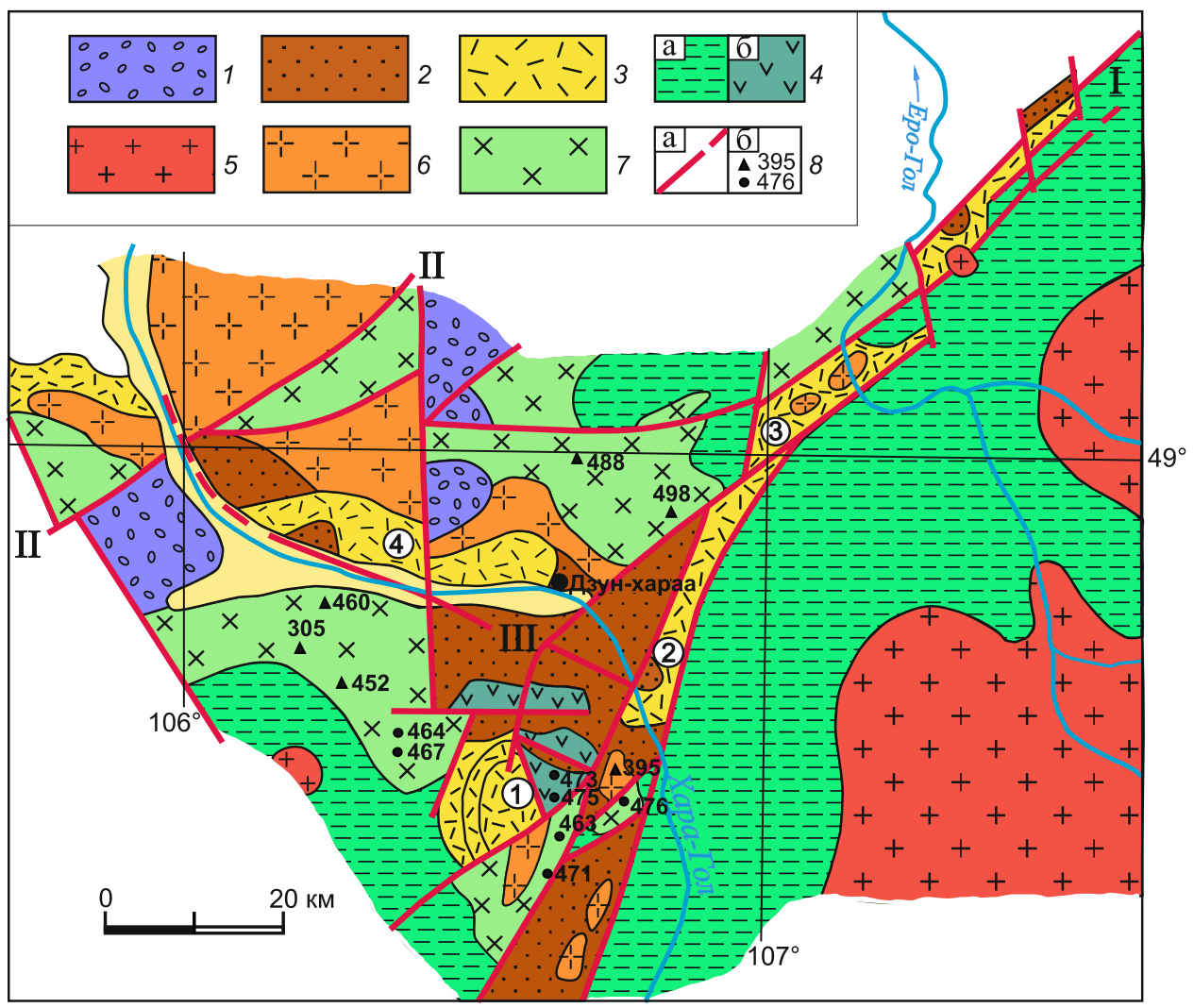

Рис. 5. Схема геологического строения вулканотектонических структур Северо-Хэнтейского поднятия (по [Gordienko, 1983, 1987; Altanzul et al., 2018]).

1 - нижне- и среднекаменноугольные отложения: конгломераты, песчаники, алевролиты, углистые аргиллиты; 2 - верхнедевонские вулканогенно-осадочные отложения: конгломераты, граувакки, песчаники, алевролиты, глинистые сланцы, зеленокаменноизмененные вулканиты кислого и среднего состава; 3 - нижне- и среднедевонские вулканогенные образования: риолитовые, дацитовые и риолит-дацитовые порфиры, их туфы и туфобрекчии; 4 - ордовикские осадочно-вулканогенные образования Харагольского спредингового бассейна (a), нижнеордовикские островодужные риолиты, дациты, андезиты и их туфы уланундурской формации (б); 5 - нерасчленненные верхнепалеозойско-мезозойские габброиды и гранитоиды; 6 - средне и верхнедевонские интрузии габбро-норитов, гранитов, граносиенитов, гранит-порфиров; 7 - ранне- и среднеордовикские интрузии островодужных гранитоидов борогольского комплекса; 8 - разрывные нарушения (а), абсолютный возраст в млн лет (б) по данным разных авторов (треугольники) и по данным монгольских и корейских геологов (кружочки) [Altanzul et al., 2018]. Byлканотектонические структуры (цифры в кружках): 1 - Дзунмодская, 2 - Мунгуликская, 3 - Ялбаг-Ерогольская, 4 - Харинская. Магмоконтролирующие глубинные разломы (римские цифры): I - Ерогольский, II - Баянгольский, III - Харинский.

Fig. 5. Geological scheme showing the volcanic-tectonic structures of the North Hentei uplift (after [Gordienko, 1983, 1987; Altanzul et al., 2018]).

1 - Lower and Middle Carbon deposits: conglomerate, sandstone, siltstone, carbonaceous argillite; 2 - Upper Devonian volcanosedimentary deposits: conglomerate, greywacke, sandstone, aleurolite, shale, metamorphosed greenstone volcanites of acidic and medium compositions; 3 - Lower-Middle Devonian volcanogenic formations: rhyolite, dacite and rhyolite-dacite porphyry, tuff and tuff breccia; 4 - Ordovician sedimentary volcanic formations of the Kharagol spreading basin (a), Lower Ordovician island-arc rhyolite, dacite, andesite and tuff of the Ulanundur formation (б); 5 - undivided Upper Paleozoic-Mesozoic gabbroid and granitoid; 6 - Middle and Upper Devonian intrusions of gabbro-norite, granite, granosyenite, granite-porphyre; 7 - Early and Middle Ordovician intrusions of island-arc granitoid of the Borogol complex; 8 - discontinuities (a), absolute age in Ma (б) according to the data from different authors (triangles) and the Mongolian and Korean geologists (circles) [Altanzul et al., 2018]. Volcano-tectonic structures (numbers in circles): 1 - Dzunmod, 2 - Mungulik, 3 - Yalbag-Erogol, 4 - Kharin. Magma-controlling deep faults (Roman numerals): I - Erogol, II - Bayangol, III - Kharin.

раннеордовикских песчано-сланцевых турбидитовых отложений. Массив имеет грубозональное строение. Его центральная часть, наиболее приподнятая в рельефе, сложена риолит-дацитами, которые в верховьях падей Арыкту, Баян-Гол и ДзунМодо-Гол занимают площадь около 70 км². Пери- ферия массива сложена кварцевыми и риолитовыми порфирами.

Возрастное положение Дзунмодской вулканической постройки на всех ранее изданных геологических картах Монголии считалось ранне-среднедевонским. Этому способствовали данные геолого- 
съемочных работ и исследований немецких геологов (Кампе и др.), которые определили раннесреднедевонский абсолютный возраст кислых вулканитов этой структуры. Эти породы были ими обнаружены в гальке перекрывающей терригенной толщи среднего - верхнего девона [Marinov, 1973b]. Однако, как указывалось выше, монгольскими и корейскими геологами были проведены специальные геохронологические исследования вулканитов Дзунмодской структуры и окружающих их гранитоидов [Altanzul et al., 2018]. Они опробовали кислые вулканиты в северо-восточной части Дзунмодской структуры, по цирконам которых (U-Pb метод) был определен раннеордовикский возраст. Эти вулканиты были отнесены к уланундурской формации. Последняя, по их данным, слагает отдельную полосу севернее Дзунмодского массива. Однако большая часть этого крупного массива (бо-

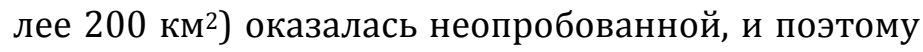
мы считаем, что не следует на основании только двух датировок, взятых практически из одного места, распространять эти данные на весь Дзунмодский массив и другие ВТС вдоль Ерогольского разлома [Gordienko, 1983]. То же самое можно сказать по полученным датировкам ордовикских гранитоидов, которые выделялись здесь и раньше (см. рис. 3,5 ).

На северных склонах Дзунмодской ВТС наряду с более ранними вулканическими извержениями в мелководных замкнутых бассейнах происходило накопление глинисто-песчано-галечных (иногда с известняками и вулканитами среднего состава) отложений формации Ажнай. Здесь выделены следующие пачки (снизу вверх): Первая пачка (мощность 80 м) конгломератовая, сложена полимиктовыми средне- и мелкогалечными конгломератами с редкими прослоями гравийных песчаников. В конгломератах наблюдается хорошо окатанная галька риолитов, андезидацитов, обломки филлитовидных сланцев, алевролитов, песчаников, алевропелитов. Вторая пачка песчаниковая (мощность от 10 до 440 м), представлена кварц-полевошпат-лититовыми песчаниками с прослоями и линзами мелкогалечных конгломератов, гравелитов, «плавающими» обломками пород и гальками. Третья пачка (до 460 м) песчаниково-алевролитовая, включает разнозернистые песчаники с прослоями алевролитов и тонкослоистых алевропелитов. Четвертая пачка алевролитовая (более 120 м), сложена чередованием алевролитов, алевропелитов с прослоями алевролитов и листоватых алевропелитов. По составу обломочной части все псаммиты типизируются как петрокластические граувакки. Возрастное положение вулканогенной толщи, находящейся в едином разрезе с терригенной, определяется нижним - средним девоном. Терригенная толща ранее по фауне брахиопод Atrypa (Spinotrypa) sp., aff. Longispina sp., cf. Unciqispina sp., Productella sp., Spirifer sp., Atrypa sp. датировалась средним-верхним девоном [Marinov, 1973a]. Однако установленные по разрезу толщи конодонты и палиноморфы позволяют ограничить время ее формирования раннефранским веком позднего девона [Minina et al., 2016a, 2017].

Все вышеперечисленные толщи прорываются массивами габброидов и гранитоидов среднего палеозоя. Нами проанализированы массивы габброидов и гранитоидов в бассейне р. Бальдж-Гол (см. рис. 3). Габброиды сложены средне- и верхнедевонскими габбро и габбро-диоритами с ${ }^{40} \mathrm{Ar}-{ }^{39} \mathrm{Ar}$ изотопным возрастом $388.7 \pm 5.6,372.0 \pm 5.5,364.2 \pm 9.9$ млн лет, а порфировидные граниты с U-Pb возрастом по цирконам $-399 \pm 5-410 \pm 6$ и 395-405 млн лет. Они прорывают мощную (до 2000 м) карбонатнопесчано-алевро-сланцевую толщу $\left(\mathrm{D}_{3}\right)$, иногда c кислыми и средними вулканитами, которая западнее долины р. Хара-Гол слагает фундамент Дзунмодской ВТС. В состав этих образований мы включаем морские карбонатно-терригенные отложения (ранее условно венд-кембрийского возраста) карьера Хутэл. Они датированы средним-поздним девоном (живет-фамен) по конодонтам Panderodus sp., Polygnatus sp. $\left(\mathrm{D}_{3}\right)$, Palmatolepis minuta Br. Et Mehl. $\left(\mathrm{D}_{3} \mathrm{fm}_{1-2}\right)$, тентакулитам Tenaculita sp. (S-D) и комплексам миоспор [Minina et al., 2016b, 2017].

Мунгуликская ВTC расположена на западных склонах хр. Мунгулик-Нуру, на левом борту долины рек Тарини-Гол и Шибир-Гол (правые притоки p. Хара-Гол). Структура вытянута вдоль Ерогольского разлома от р. Хара-Гол до верховья р. ЯлбагГол на расстояние 30 км при ширине от 5 (вблизи устья р. Тарини-Гол) до 1.0-1.5 км (в бассейне рек Салинчийн-Гол и Халисин-Булак). Поперечными и продольными сбросами поле разбито на ряд приподнятых и опущенных блоков, сложенных нижнеи среднедевонскими вулканитами. Наиболее мощные накопления вулканитов наблюдаются на югозападном фланге структуры, в зоне сочленения Ерогольского и Харинского разломов, где Мунгуликское поле сменяется субширотной полосой грабен-синклинальных структур северной окраины Дзунмодского массива (рис. 5). На левом борту долины р. Тарини-Гол, в приустьевой части, севернее ур. Унгулик, вскрыты мощные (500-600 м) потоки риолитов, круто $\left(70^{\circ}\right)$ падающие на северо-запад. По облику и составу риолиты сходны с аналогичными породами Дзунмодского вулканического массива. Риолитовые лавы иногда содержат обломки андезитовых порфиритов и пород фундамента (кристаллических сланцев). Южнее р. Хургули они перекрыты толщей конгломератов позднедевонского - раннекаменноугольного возраста, в кото- 
рых галька представлена в основном кварцевыми и фельзитовыми порфирами, а также кристаллическими сланцами, кремнистыми породами и кварцем (гальки гранитов и других интрузивных пород не обнаружены).

Далее к северо-востоку в разрезах вулканитов Мунгуликского поля появляются флюидальные лавы и туфы риолитов, в том числе туфы с игнимбритоподобным цементом (например, в окрестностях дома отдыха Таринийн-Амралт). Они прорваны небольшими телами гранодиоритов и гранодиорит-порфиров с редкими порфировыми выделениями роговой обманки и калиевого полевого шпата. Видимая мощность вулканических накоплений в Мунгуликском вулканическом поле оценивается нами в пределах 1000 м.

Ялбаг-Ерогольская ВТС расположена вдоль Ерогольского разлома и является северо-восточным продолжением Мунгуликской зоны. Ялбаг-Ерогольское вулканическое поле представлено сложной системой грабенов и горстов северо-восточного простирания, протягивающихся от бассейна р. Хэрэйн-Гол на расстояние более 50 км при ширине полосы от 1-2 до 8-10 км. Вулканиты нижнего среднего девона совместно с нижнепалеозойскими метаморфическими породами харинской серии и более поздними интрузиями габброидов зажаты в тектонических клиньях. По зонам разломов они подвергнуты интенсивному динамотермальному метаморфизму, рассланцеванию, катаклазу и милонитизации вплоть до образования филлонитов и разнообразных будинажных структур. На более детально изученном юго-западном фланге ЯлбагЕрогольского поля вулканиты обнажены в отдельных блоках на площади около 100 км². Здесь, в верховье р. Ялбаг-Гол (по ее левому притоку УртуинГол), вскрыты мощные потоки и субвулканические тела риолитов и фельзитов. По южным склонам горы Ундур-Цаган они окружены потоками кластолав и брекчиевых риолитовых лав с почти вертикальной флюидальностью. Далее к северо-востоку, по правобережью р. Еро-Гол, нижне- и среднедевонские вулканиты наблюдаются в виде полосы изолированных грабенов размером (1-2)×(5-8) км, сдвинутых один относительно другого на 1-2 км поперечным сбросо-сдвигом. По правому борту долины р. Хэрэни-Гол (правый приток р. Еро-Гол) полоса грабенов выклинивается в зоне Ерогольского разлома, где появляются молассовые каменноугольные отложения, которые перекрывают нижне- и среднедевонские вулканиты.

Фрагменты крупной Харинской ВТС наблюдаются по правобережью среднего течения р. Хара-Гол, к западу и северу от ст. Дзун-Хара. Здесь, в зоне сближенного развития Баянгольского и Ерогольского разломов, на площади около 1000 км² вскры- та нижне-среднедевонская вулканоплутоническая ассоциация пород. С юга и севера вулканическое поле ограничено поперечными разломами. На востоке поле сочленяется по субширотному разлому с девонскими вулканотектоническими структурами Ерогольского разлома, с запада перекрыто пермскими вулканитами. Полоса вулканогенных пород обнажена по правому борту долины р. Хара-Гол от ст. Дзун-Хара до ст. Баян-Гол на площади примерно

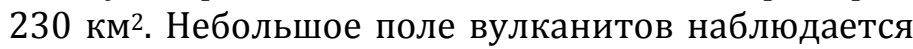
на левобережье р. Хара-Гол, южнее горы Бага-Номгон. Вулканические породы представлены неравномерно окварцованными туфами и туфобрекчиями риолитов и гранит-порфиров.

Породы Харинской ВТС прорываются крупными массивами гранитов, граносиенитов и гранодиоритов. Их девонский возраст подтверждается перекрытием нижне- и среднекаменноугольными отложениями с брахиоподовой фауной. Кроме того, они близки по возрасту вулканоплутоническим ассоциациям других ВТС Хэнтей-Даурской АКО, в том числе в бассейне реки Чикой Центрального Забайкалья, где по Котыйскому гранитоидному массиву получен U-Pb возраст по цирконам (SHRIMP II)

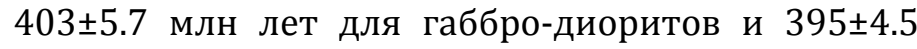
млн лет для гранитов [Gordienko et al., 2012a].

Лунская ВТС образовалась в левом крыле Ерогольского глубинного разлома на значительном (150 км) удалении от Дзунмодской ВТС. Она расположена на левобережье реки Туул-Гол, в 15 км к северо-западу от Лун-сомона. В ее строении принимают участие (снизу вверх): 1) осадочно-вулканогенная толща (мощность около 500 м), сложена разнообразными туфами, туфопесчаниками и гравелитами с фауной нижнего девона; 2) вулканогенная толща (мощность 700 м) андезит-риолитового состава с горизонтами (от 2 до 25 м) туфов и лавобрекчий нижнего и среднего девона, в нижней части еe разреза преобладают плагиоклазовые и пироксен-плагиоклазовые андезиты, андезибазальты, сменяющиеся выше дацитами, риолитами и их туфами; 3) граувакковая толща среднего девона (мощность 400-500 м), сложенная граувакковыми разнозернистыми, слабосортированными песчаниками с прослоями и линзами среднегалечных конгломератов, гравелитов в нижней части разреза, вверх по разрезу преобладают песчаники среднезернистые с плавающей галькой и прослоями темно-серых, зеленоватых алевролитов и алевропелитов с фауной и флорой нижнего - среднего девона.

Интрузивные породы Лунской ВТС изучены по лево- и правобережью р. Туул-Гол. Они представлены более ранними амфибол-биотитовыми и биотитовыми гранодиоритами и гранитами, среди которых встречаются небольшие выходы габбро, 
габбро-диоритов и диоритов. Гранитоиды редко секутся дайками долеритов и дацитовых порфиритов. Массив прорывает терригенные породы харинской серии $\left(\epsilon_{2}-\mathrm{O}_{1}\right)$ и осадочно-вулканогенную толщу нижнего - среднего девона. Эта ассоциация девонских вулканогенных и осадочных пород сопоставляется по составу и возрасту с Дзунмодской ВТС Хэнтей-Даурской системы.

\subsection{4. Адацаг-Ононско-Агинская зона силур-девонского океанического и островодужного осадконакопления и магматизма}

В Адацаг-Ононско-Агинскую CФЗ-IV включены породы аккреционных комплексов различной геодинамической природы. По геологическим данным при формировании Харагольского спредингового бассейна Монголо-Охотского океана в юго-восточной (в современных координатах) части в конце силура произошло его расширение и закупорка за счет лавинной седиментации и образования мощной флишоидной толщи, что способствовало перемещению зон спрединга и субдукции к юго-востоку, где на активных окраинах Идэрмэг-ЭрэндаваКеруленского составного микроконтинента образовался крупный Восточно-Хэнтейский океанический бассейн и связанная с его развитием АдацагОнонско-Агинская надсубдукционная островодужная система (см. рис. 2).

Механизм процессов стагнации слэбов, их перемещение и появление задуговых и междуговых бассейнов подробно рассмотрены в работе Ю.А. Зорина с соавторами [Zorin et al., 2009]. По данным этих исследователей, при замедлении скорости субдукции растяжение в междуговом бассейне может смениться сжатием и бассейн начнет закрываться. Все здесь зависит от деформационных свойств коры и мантии. При дальнейшем развитии сжатия литосферная мантия может замениться астеносферой, что приведет к рифтогенезу и появлению новых зон спрединга и субдукции. По-видимому, подобный механизм формирования зон субдукции (сжатия) и зон спрединга (растяжения) мог сработать при заложении и развитии Восточно-Хэнтейского океанического бассейна.

Восточно-Хэнтейский океанический бассейн и входящий в его состав Улан-Баторский террейн протягиваются широкой полосой (80-120 км) от Южного Хэнтея (верховье реки Туул-Гол) и Адацага на северо-восток до Агинской зоны Восточного Забайкалья на расстояние свыше 700 км [Dorjsuren et al., 2006; Gordienko et al., 2017]. Бассейн сложен в основном девонскими гемипелагическими кремнистыми отложениями с базальтовыми лавами, красными радиоляриевыми яшмами, криноидными из- вестняками с силур-девонскими конодонтами в гайотах и аккреционных призмах Хэнтейской серии. Эти комплексы ранее интерпретировались как мощные осадочные морские бассейновые отложения, залегающие на неопротерозойском фундаменте. Однако в последующем было установлено, что девонские радиоляриевые кремнистые породы наряду с базальтами в этой формации не содержат крупнозернистых терригенных обломочных пород и изменяются постепенно до кремнистых сланцев и затем до сланцев и песчаников. Эти фациальные изменения сходны с океаническими разрезами, которые представлены в виде постепенного фациального перехода, произошедшего благодаря движению океанической коры в зоне субдукции, от пелагических глубоководных радиоляриевых кремнистых пород, залегающих над океаническими пиллоу-базальтами, к гемипелагическим кремнистым сланцам и, далее, терригенным турбидитам. Продолжительное формирование осадочно-вулканогенных пород характеризовалось чередованием напластований кремнистых и обломочных пород, что свидетельствует о их осаждении на обширном открытом океаническом дне [Ruppen et al., 2014].

В стратиграфическом отношении Хэнтейская серия подразделяется на формации Сэргэлен (ранний девон) и Горхи (средний - поздний девон), которые расположены восточнее города Улан-Батора, в верховьях рек Туул-Гол, Тэрэлж и Минж. Формация Сэргэлен представлена кварцитами, кремнистыми сланцами, метаэффузивами основного и среднего состава, линзами известняков, кварц-хлорит-серицитовыми сланцами, песчаниками. Группа Горхи расположена восточнее города Улан-Батора, в верховьях рек Туул-Гол, Тэрэлж и Минж. Она представлена песчаниками, аргиллитами, глинистыми сланцами, красными кремнистыми сланцами с радиоляриями, мраморизованными известняками. В горизонтах кремнистых сланцев встречаются «закатанные» линзовидные тела базальтов N-MORB типа, долеритов, габбро-долеритов. Разрез толщи хорошо виден вдоль реки Туул-Гол, ее мощность составляет 1500-2000 м. Предыдущими исследователями в известняках были найдены девонские криноидеи, в кремнистых сланцах - раннеи среднедевонские радиолярии, а также конодонты с возрастом от позднесилурийских до средне- и позднедевонских [Kashiwagi et al., 2004; Kurihara et $a l ., 2006]$. В тектонически нарушенных слоях формации Горхи идентифицирована типичная океанская плитная стратиграфия с пелагическими, гемипелагическими и турбидитовыми отложениями [Ruppen et al., 2014].

Девонская вулканогенно-терригенно-карбонатная толща формации Горхи изучалась в местности Шохой Цаган Булаг, по левобережью Туул-Гол. Рас- 
положена в 60 км на восток от г. Улан-Батора. Толща залегает с падением под углом $70^{\circ}$ на северозапад и представлена песчаниками, алевритами, красными и белыми кремнистыми сланцами, темно-зелеными базальтами OІВ типа, коричнево-серыми и пурпурными андезитовыми туфами, белыми известняками и чередованием темных кремнистых и глинистых сланцев. Хорошо вскрытый контакт известняков, окружающих базальтов и туфов виден в северной части разреза. Размер известняковой линзы и ее фрагментов варьируется от нескольких сантиметров до 10 м. В восточной части обнажения в известняковой линзе обнаружены криноидеи, а в кремнистых сланцах - радиолярии, что говорит о девонском возрасте пород [Kurihara et al., 2006]. Нами в известняках выделены верхнедевонские фаменские конодонты Polygnathus glaber Ulr. et Bass. и комплекс миоспор [Minina et al., 2016a, 2017]. Монгольские, американские и швейцарские исследователи, работавшие в этом районе, считают, что вскрывается девонский океанический симаунт. Изучение редкоземельных элементов (РЗЭ) базальтов в местности Шохой Цаган Булаг четко указывает на присутствие OІB. Геохимические и литостратиграфические наблюдения позволяют восстановить эволюцию симаунта, начиная от его развития в мелководье и заканчивая погружением, связанным с субдукцией, которая, в свою очередь, связана с последующим осаждением радиоляриевого кремня, гемипелагических сланцев и турбидитовых песчаников [Kurihara et al., 2006; Kelty et al., 2008; Ruppen et al., 2014].

Как указывалось выше, широкая полоса океанических пород протягивается вдоль бассейна верхнего течения реки Туул-гол, верховьев рек Керулен и Онон в Восточное Забайкалье, где образует Агинский и Агуца-Кыранский океанические бассейны.

В Агинском океаническом бассейне было два цикла образования океанической коры: в ордовике и позднем силуре - девоне (см. рис. 4). По- видимому, раскрытие океанического бассейна началось в среднем ордовике и продолжалось с перерывами до конца девона. Фациальные и геохимические особенности изученных базальтов и кремнистых пород указывают на гемипелагическую обстановку их формирования на океанической коре в спрединговой зоне Монголо-Охотского океана.

До недавнего времени оставался дискуссионным возраст ононской свиты, который неоднократно пересматривался (силур, поздний протерозой, рифей). Свита сложена метаморфизованными песчаниками, филлитизированными алевролитами с горизонтами метаэффузивов основного и среднего состава. В результате совместных исследований с читинскими геологами получены новые данные о возрасте ононской свиты (среднее течение рек Онон и Ага). Из отложений свиты выделен представительный комплекс микрофоссилий. В составе палинокомплекса преобладают типичные позднесилурийские виды акритарх (микрофитопланктон), миоспор, впервые появляющиеся с верхнего силура хитинозои Desmochitina urna Eis. (O-S), позволяющие ограничить время формирования отложений поздним силуром [Kurilenko et al., 2015].

В Агуца-Кыранском прогибе юга Восточного Забайкалья (рис. 6) метабазальты кулиндинской, агуцинской и ононской свит близки по геохимическому составу породам Онон-Кулиндинского блока Агинского прогиба. По своим характеристикам (низкий титан и фосфор, умеренное содержание $\mathrm{Nb}$ и $\mathrm{Zr}$ ) изученные породы наиболее близки базальтам срединно-океанических хребтов (типа $\mathrm{N}$-MORB). Сонахождение метавулканитов с глубоководными осадками позволяет предположить, что метабазальты Агуца-Кыранского бассейна образовались в пределах срединно-океанического хребта [Medvedev et al., 2007].

На юго-восточной окраине Восточно-Хэнтейского океанического бассейна в связи с формированием протяженной зоны субдукции образовались Эрдэни-Адацагские надсубдукционные офиолитовые комплексы силур-девонского возраста.

Адацагские офиолиты расположены в 180 км к югу от Улан-Батора, где образуют протяженную зону, контролируемую Адацаг-Ононским глубинным разломом северо-восточного простирания (см. рис. 2; рис. 7). Изученный офиолитовый комплекс представляет фрагменты океанической коры Монголо-Охотского океана [Gornova et al., 2004; Gordienko, 2006; Tomurtogoo et al., 2005].

По петролого-геохимическим параметрам офиолитовый комплекс относится к надсубдукционным образованиям. Он состоит из серпентинитового меланжа, кумулятивной и расслоенной габброидной серии, долеритовых даек, кремнистых пород и лав базальтового, андезибазальтового состава. Последние имеют типичный толеитовый тренд дифференциации с увеличением железистости.

По уровню содержаний РЗЭ базальты и андезибазальты соответствуют толеитам островных дуг. Это подтверждается отчетливыми минимумами по $\mathrm{Nb}, \mathrm{Ta}, \mathrm{Zr}, \mathrm{Hf}, \mathrm{Ti}$. Аналогичное распределение состава РЗЭ имеют долериты и габбро-пироксениты, что позволяет объединить их в составе единого островодужного комплекса, характерного для энсиматических островных дуг. Силур-девонский возраст адацагских офиолитов определяется налеганием на них нижне- и среднекаменноугольной терригенной толщи, широко распространенной в районе (рис. 7). Пегматоидное габбро, по которому был определен среднекаменноугольный возраст 325.4 1.1 


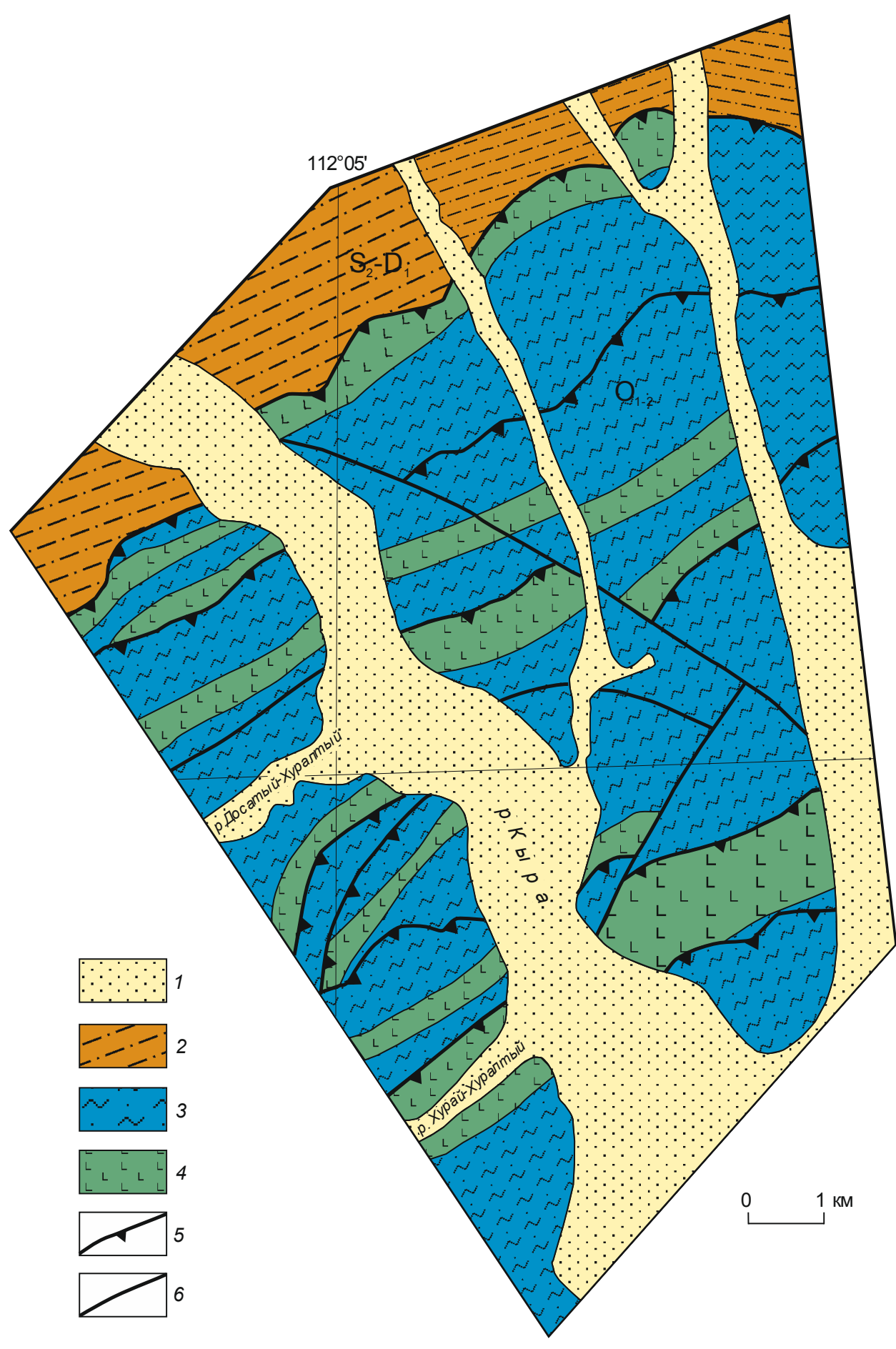

Рис. 6. Геологическая схема Агуца-Кыранского прогиба в бассейне р. Кыра (Восточное Забайкалье) (по [Medvedev et al., 2007] с дополнениями).

1 - четвертичные отложения; 2 - агуцинская и ононская свиты $\left(\mathrm{S}_{2}-\mathrm{D}_{1}\right)$ : песчаники и филлиты с горизонтами известняков, кварцитов и метабазальтов; 3 - кулиндинская свита $\left(\mathrm{O}_{1-2}\right)$ : кварц-хлорит-серицитовые, серицит-хлоритовые сланцы, микрокварциты с горизонтами метабазальтов и линзами яшмоидов; 4 - основные ортосланцы и метабазальты; 5 - взбросы и надвиги; 6 - разрывные нарушения.

Fig. 6. Geological scheme of the Agutsa-Kyra trough in the Kyra River valley (Eastern Transbaikalia) (after [Medvedev et al., 2007], including additional data).

1 - Quaternary sediments; 2 - Agutsa and Onon suites ( $\left.\mathrm{S}_{2}-\mathrm{D}_{1}\right)$ : sandstone and phyllite with limestone, quartzite and metabasalt horizons; 3 - Kulinda suite $\left(\mathrm{O}_{1-2}\right)$ : quartz-chlorite-sericite, sericite-chlorite shale, microquartzite metabasalt horizons and jasper lenses; 4 - basic orthoschist and metabasalt; 5 - reverse and thrust faults; 6 - discontinuities. 


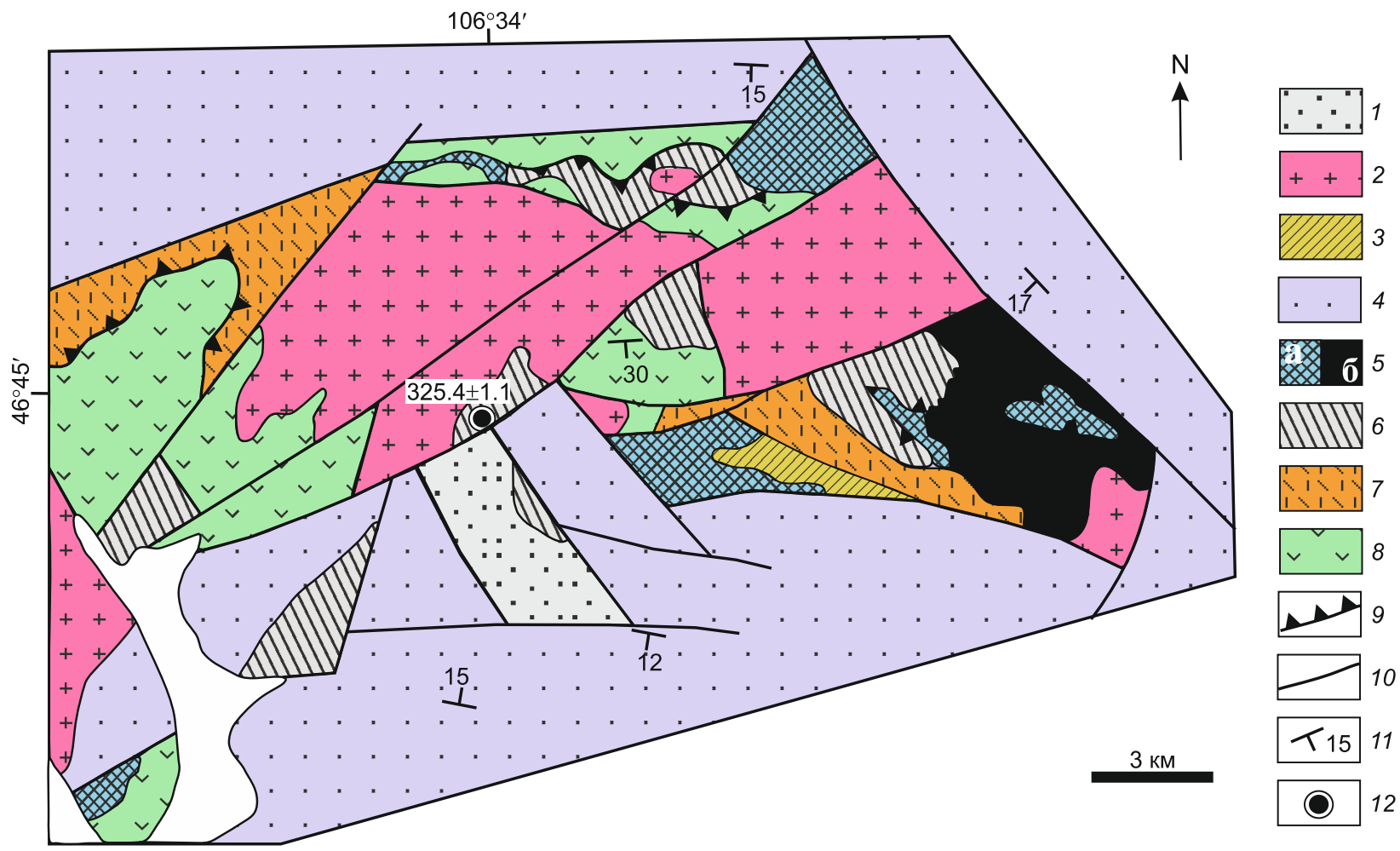

Рис. 7. Схема геологического строения офиолитового комплекса Адацага (по [Tomurtogoo et al., 2005]).

1 - верхнемеловые песчаники и конгломераты; 2 - позднетриасовые и раннеюрские граниты; 3 - пермские риолиты; 4 - нижнеи среднекаменноугольные конгломераты, песчаники, алевролиты и аргиллиты; 5-8 - силур-девонские офиолитовые ассоциации: 5 - серпентиниты (а), серпентинитовый меланж (б), 6 - габбро, габбро-пироксениты, расслоеное и кумулятивное габбро, 7 - комплекс параллельных даек, 8 - толща базальтов, андезибазальтов и кремнистых пород; 9 - надвиги; 10 - разломы и другие геологические границы; 11 - элементы залегания пород; 12 - место отбора пробы лейкогаббро и ее абсолютный возраст (млн лет).

Fig. 7. Schematic geological structure of the Adatsag ophiolite complex (after [Tomurtogoo et al., 2005]).

1 - Upper Cretaceous sandstone and conglomerate; 2 - Late Triassic and Early Jurassic granite; 3 - Permian rhyolite; 4 - Lower and Medium Carbonic conglomerate, sandstone, siltstone and argillite; 5-8-Silurian-Devonian ophiolite associations: 5 - serpentinite (a), serpentinite melange (б), 6 - gabbro, gabbro-pyroxenite, stratified and cumulative gabbro, 7 - complex of parallel dykes, 8 - stratum of basalt, andesite basalt and siliceous rocks; 9 - thrusts; 10 - faults and other geological boundaries; 11 - dip and strike; 12 - sampling site of leukogabbro and its absolute age (Ma).

[Tomurtogoo et al., 2005], находится в ксенолите среди мезозойских гранитов и не может быть членом офиолитовой ассоциации.

На продолжении Адацаг-Ононского разлома, в междуречье Туул-Керулен в районе сомона Эрдэнэ Восточного Хэнтея, также изучены офиолитовые и другие сопровождающие их осадочно-метаморфические и магматические образования (рис. 8).

Изучение эрдэнэ-керуленских офиолитов показало, что наиболее древними породами в их составе являются линзы и бескорневые неправильные тела серпентинизированных гипербазитов в низах разрезов силур-девонской осадочно-метаморфической толщи. Гипербазиты, по-видимому, слагают основание офиолитовой ассоциации. Следующей группой пород, вероятно, являлись габброиды. В результате наших работ были обнаружены разнообразные габброиды. Это прежде всего расслоенные пироксениты и габбро-пироксениты, а также пегматоидное лейкократовое габбро, которое, так же как и в офиолитах Адацага, характеризует внутриплитный магматизм с возрастом $279.5 \pm 11.5$ млн лет и никакого отношения к офиолитовому комплексу не имеет. В пироксен-роговообманковом полосчатом и неравномерно-зернистом габбро обнаружены жило- и дайкообразные тела долеритов. Эта ситуация может рассматриваться как область зарождения даек. Дайки являлись подводящими каналами для излияния на дно глубоководного океанического спредингового бассейна лав толеитовых базальтов.

Наличие офиолитов, базальтов и андезибазальтов среди осадочно-метаморфической толщи, сложенной пелагическими осадками (кремнистыми, углеродистыми отложениями, микрокварцитами и др.), подтверждает глубоководный характер спре- 


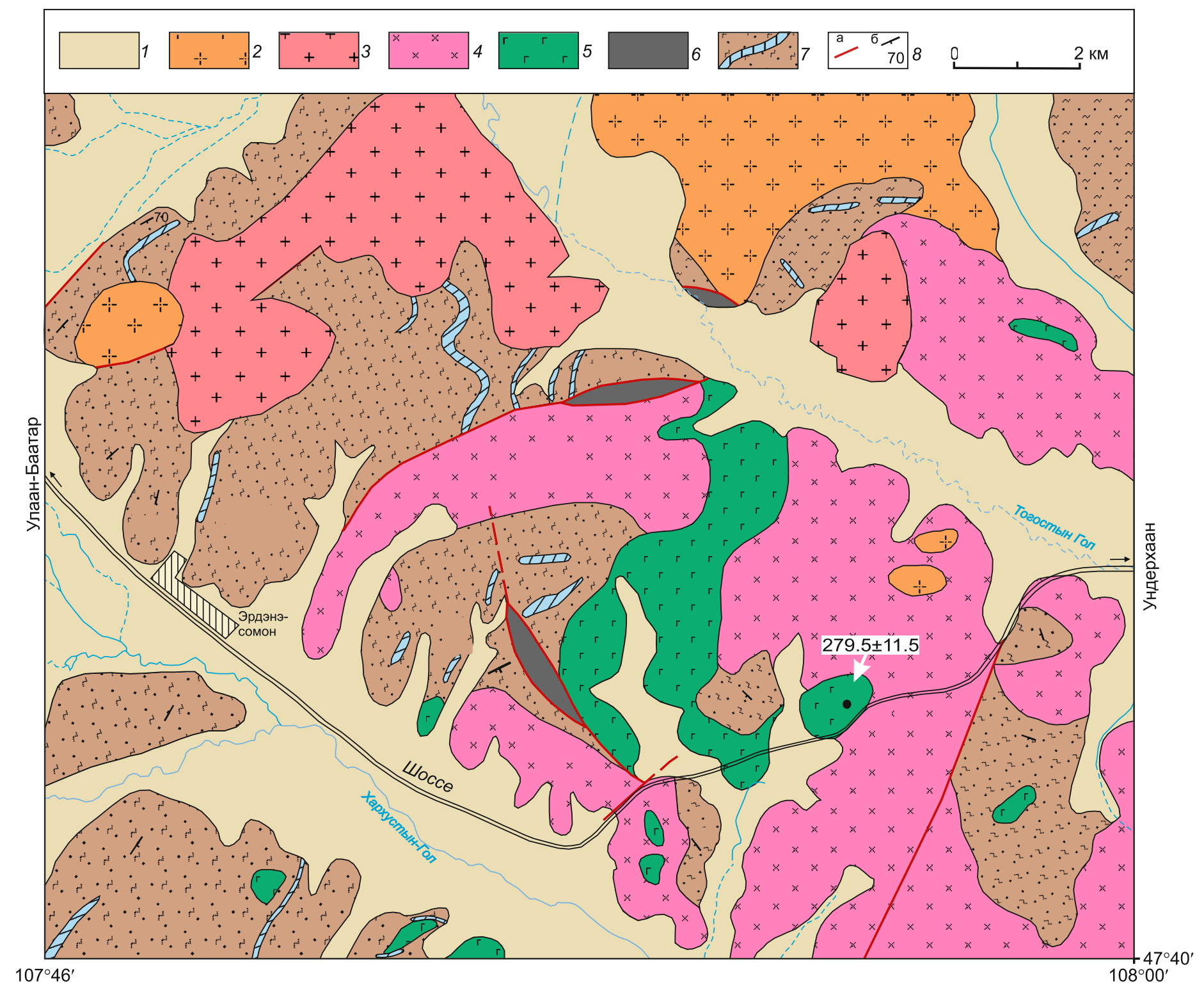

Рис. 8. Схема геологического строения междуречья Туул-гол-Керулен (Восточный Хэнтей) (составлена И.В. Гордиенко с использованием материалов монгольских геолого-съемочных работ и собственных наблюдений).

1 - четвертичные отложения; 2 - триасово-юрские граносиениты и гранит-порфиры; 3-5 - средне- и верхнепалеозойские интрузивные комплексы: 3 - граниты, 4 - граниты и гранодиориты, 5 - габброиды; 6 - силур-девонская офиолитовая ассоциация (серпентинизированные базит-гипербазиты, меланж); 7 - нерасчлененная осадочно-метаморфическая толща раннего девона (кварциты, кремнистые и кремнисто-углистые сланцы, афировые и миндалекаменные базальты, дациты) и позднего девона раннего карбона (песчаники, алевролиты, массивные и тонкополосчатые, иногда углеродистые известняки); 8 - разрывные нарушения (а), элементы залегания (б).

Fig. 8. Schematic geological structure of the area between the Tuul-gol and Kerulen Rivers (Eastern Hentei) (compiled by I.V. Gordienko using own observations and the Mongolian geological survey data).

1 - Quaternary sediments; 2 - Triassic-Jurassic granosyenite and granite-porphyry; 3-5 - Middle-Upper Paleozoic intrusive complexes: 3 - granite, 4 - granite and granodiorite, 5 - gabbroid, 6 - Silurian-Devonian ophiolite association (serpentinized basite-hyperbasite, melange); 7 - undivided sedimentary-metamorphic stratum of the Early Devonian (quartzite, siliceous and siliceous-carbonaceous shale, aphyrous and amygdaloidal basalt, dacite) and Late Devonian - Early Carboniferous (sandstone, aleurolite, massive and laminated limestone, rare carbon limestone); 8 - discontinuities (a), dip and strike (б).

дингового океанического бассейна Восточного Хэнтея. В последующем они были в разной степени изменены гидротермальными процессами при фумарольно-сульфатарной деятельности на дне бас- сейна. В перекрывающих осадочно- метаморфическую толщу известняках и углистых алевролитах с прослоями алевропелитов нами установлены фаменские конодонты Palmatolepis minuta Br. et Mehl. 
$\left(D_{3} \mathrm{fm}_{1-2}\right)$ и комплекс миоспор $\left(\mathrm{D}_{3} \mathrm{fm}-\mathrm{C}_{1} \mathrm{t}\right)$. Возраст этих отложений определен как позднедевонскораннекаменноугольный.

\subsection{5. Позднекаледонская активная окраина Идэрмэг-Эрэндава-Керуленского микроконтинента}

Идэрмэг-Эрэндава-Керуленский составной микроконтинент сложен несколькими структурно-вещественными комплексами. В фундаменте вскрываются отложения неопротерозоя и раннего палеозоя, включая среднепротерозойский гнейсовокристаллический комплекс (формация ХаучинГол), зеленосланцевые осадочные комплексы формации Эрэндава и перекрывающие карбонатнотерригенные комплексы эдиакария - нижнего кембрия Керуленского блока [Tomurtogoo, 2014]. По данным [Badarch et al., 2002], террейн Эрэндава включает палеопротерозойские гнейсы, амфиболиты, сланцы и мраморы, неопротерозойские черные сланцы, несогласно перекрытые нижнесилурийскими морскими отложениями и девон-пермскими породами, коррелирующими со Среднегобийским вулканоплутоническим поясом [Bussien et al., 2011].

Из-за отсутствия палеомагнитных данных и исходя из общей геологической ситуации проявления энсиматического островодужного магматизма, мы полагаем, что Адацаг-Ононско-Агинская островодужно-океаническая система могла располагаться на окраине океана, вблизи древнего микроконтинента, вероятно Идэрмэг-Эрэндава-Керуленского, и примыкающей к нему девонской Онон-Норовлинской энсиалической островной дуги [Gordienko, 1987; Zorin et al., 1998]. Вместе с одновозрастными островодужными образованиями прилегающих Аргунского и Ольдойского террейнов МОСП составляла части единой активной континентальной окраины Сибирского палеоконтинента МонголоОхотского океана [Sorokin et al., 2015; Gordienko et al., 2018].

\subsection{6. Перекрывающие осадочные бассейны и сшивающие магматические комплексы в аккреционных призмах Хэнтей-Даурской складчатой системы}

Среди перекрывающих и сшивающих структурно-вещественных комплексов Хэнтей-Даурской системы широко распространены средне- и позднедевонские сланцево-терригенно-карбонатные отложения, а также ранне- и среднекаменноугольные терригенно-молассовые отложения, которые представляли преддуговые или задуговые бассейны и в настоящее время залегают в аккреционных приз- мах Хэнтей-Даурской системы. Кроме того, в пределах этих структур произошло массовое внедрение внутриплитных сшивающих магматических комплексов позднего палеозоя и мезозоя, в результате которых был сформирован современный облик Хэнтей-Даурской складчатой системы.

Нами были получены новые материалы по складчатому обрамлению девонского Дзунмодского вулканического массива островодужного типа. Здесь по левому борту долины реки Хара-гол и по северному обрамлению массива был уточнен возраст ранее выделенной средневерхнедевонской терригенно-карбонатной толщи [Gordienko, 1983, 1987], которая перекрывает нижнеордовикскую уланундерскую формацию. Изучены отложения, распространенные по падям Баян-Гол и Улан-Билутай-Ам, где они представлены чередованием зеленовато-серых полимиктовых, вулканомиктовых песчаников, известковистых мелкозернистых песчаников и алевролитов, филлитовидных сланцев, конгломератов с прослоями туффитов, туфов. Их возраст по конодонтам Palmatolepis transitans Mull. $\left(\mathrm{D}_{3} \mathrm{f}\right)$, хитинозоям Conochitina sp. (D), плауновидным и комплексу миоспор определен как средний фран [Minina et al., 2017]. Подобные отложения были изучены также к юго-западу от Дзунмодского вулканического массива, к северу от Лун сомона. Здесь они представлены ритмичным чередованием неравномерно метаморфизованных терригенных пород, время формирования которых по миоспорам определяется позднефранским веком позднего девона.

На территории Монголии широким распространением пользуются разнообразные каменноугольные отложения, особенно в пределах Хангай-Хэнтей-Даурской складчатой системы, формировавшиеся в крупном морском бассейне. Среди них преобладают нижне- и среднекаменноугольные отложения, которые «плащом» покрывали огромную территорию [Amantov et al., 1970].

В Хэнтей-Даурской системе эти отложения образуют широкую полосу в ее центральной части, где наращивают девонские океанические отложения Улан-Баторского, Восточно-Хэнтейского и Даурского прогибов. Менее распространены каменноугольные терригенно-молассовые отложения в пределах Орхон-Шарынгольского, Чикойского прогибов, а также в пределах силур-девонской Еро-ДзунмодЛунской и Адацаг-Ононско-Агинской островодужных систем.

Каменноугольные отложения в Улан-Баторском прогибе несогласно залегают на девонском аккреционном комплексе и относятся к формациям Алтановоо (нижний карбон) и Оргиоч (нижний и верхний карбон). Формация Алтановоо находится в верховьях рек Тэрэлж и Хэрлен и в долине р. Туул- 


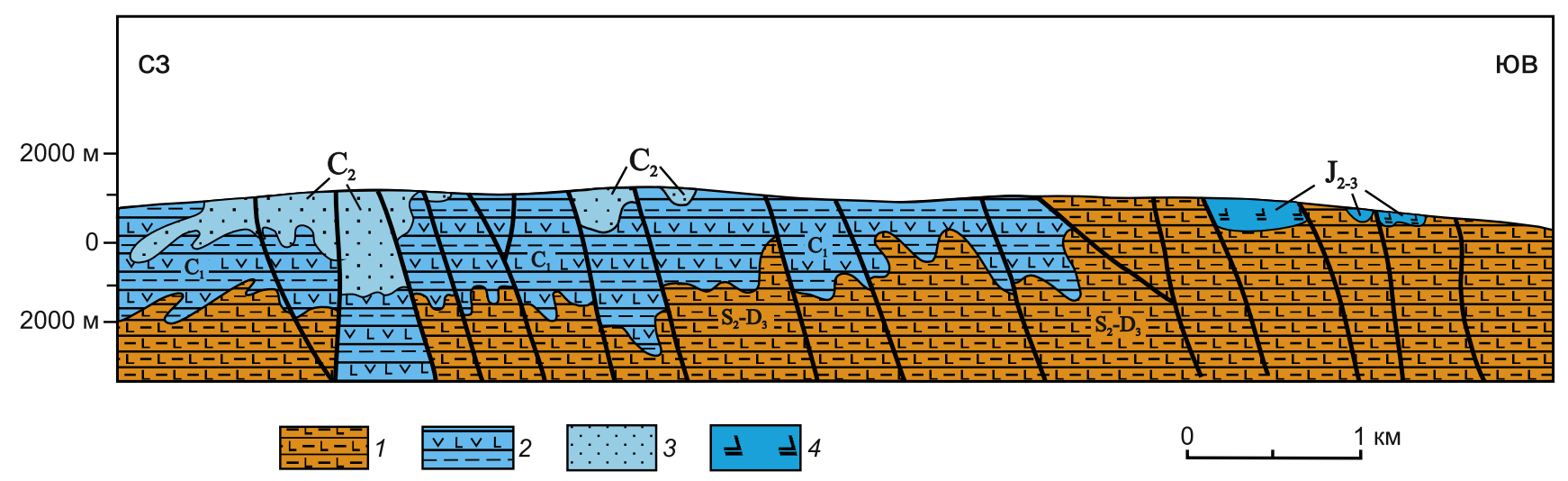

Рис. 9. Геологический профиль через Даурский прогиб (по [Gordienko, 1987]).

1 - верхний силур-девонские сланцево-кремнистые-граувакковые отложения с океаническими базальтами и силлами метадолеритов (ононская, агуцинская, горячинская свиты); 2 - раннекаменноугольные кремнисто-песчано-сланцевые отложения с горизонтами яшм, базальтов, андезибазальтов и силлов долеритов (киркунская, дабангорхонская свиты); 3 - среднекаменноугольные песчано-граувакковые турбидитовые отложения (рябиновская свита); 4 - средне-верхнеюрская вулканогенная толща дацит-андезитового состава.

Fig. 9. Geological profile across the Dauria trough (after [Gordienko, 1987]).

1 - Upper Silurian-Devonian shale-siliceous-greywacke deposits with oceanic basalts and metadolerite sills (Onon, Agutsin, and Goryachinsk suites); 2 - Early Carboniferous siliceous-sandy-shale deposits with horizons of jasper, basalt, andesibasalt and dolerite sills (Kirkun, and Dabargorkhon suites); 3 - Medium Carbon sandy-graywacke turbidite deposits (Ryabinovskaya suite); 4 - Middle Upper Jurassic volcanogenic stratum of dacite-andesite composition).

Гол. Она сложена флишевыми аргиллитами, песчаниками, гравелитами, глинистыми сланцами и конгломератами, общей мощностью 2500-3000 м. В конгломератах имеется галька гранитов, кварцитов, кристаллических сланцев, кислых эффузивов и белого кварца. Состав гальки говорит о большом сходстве с ордовикско-силурскими породами террейна Асральт-Хаирхан. В алевро-песчанистом горизонте обнаружены нижнекаменноугольные (визейские) мшанки - Fenestella invulgata Shishova, Lyrocladia mariae Shishova., Sulcoretepora mergensis Nekhoroshev, в песчаниках были найдены брахиоподы - Spirifer dublicicostus Mart. Формация Оргиоч расположена в долине Диндин и залегает согласно на нижнекаменноугольной формации Алтановоо. Породы представлены зелеными песчаниками, гравелитами, конгломератами, филлитами и алевролитами. Мощность формации 2500 м. Породы подвержены изоклинальной складчатости [Dorjsuren et al., 2006]. В алевролитах формации Алтановоо нами выделен нижнекаменноугольный турнейско-визейский комплекс миоспор [Minina et al., 2016b].

На юге Восточного Забайкалья в пограничных районах с Монголией нижне- и среднекаменноугольные отложения широко распространены в Даурском прогибе, где они объединены в ингодинскую серию, породы которой перекрывают, а иногда и продолжают разрезы силур-девонских отложений ононской, агуцинской и горячинской свит (рис. 9). В ингодинской серии выделяются киркунская, дабангорхонская и рябиновская свиты нижнего и среднего карбона. нижнекаменноугольные киркунская и дабангорхонская свиты сложены сланцево-кремнисто-граувакковыми отложениями с горизонтами базальтов, амфиболитов и глубоководных кремнистых пород, относящихся к аспидно-граувакковой формации. Среднекаменноугольная рябиновская свита перекрывает с несогласием вышеназванные свиты и представлена песчано-граувакковыми турбидитовыми отложениями. В целом, возраст ингодинской серии по остаткам брахиопод, мшанок и фораминифер соответствует нижне-среднекаменноугольным отложениям. Они сопоставляются с гутайской свитой $\left(\mathrm{C}_{1-2} \mathrm{gt}\right)$ бассейна реки Чикой [Gordienko, 1987; Anashkina et al., 1997].

Давно известные каменноугольные отложения урмугтэйульской формации [Sizova, 1935] Хэнтейской серии Западного Хэнтея изучались нами по рекам Шарын-Гол и Хара-Гол (Орхон-Шарынгольский прогиб). Исследованиями по р. Шарын-Гол в составе формации найдены растительные остатки, представленные филлоидами и спорофиллами эндемичных плауновидных, облиственными побегами примитивных войновскиевых и др. Комплекс миоспор определяет раннекаменноугольное, турнейское время накопления отложений. Кроме того, определены криноидеи, представленные визейско- 
башкирским Priscusicrinus priscus (Stukalina), поздневизейско-серпуховскими Uniformicrinus uniformis (Stukalina) и Ovalicrinus ellipticus (Stukalina) (последние характерны для мергенского горизонта Забайкалья). Миоспоры ограничивают время формирования отложений визейско-серпуховским веком раннего карбона. Таким образом, по нашим данным, возраст формации раннекаменноугольный, причем нижняя часть разреза накапливалась в турнейское, а верхняя часть - в визейско-серпуховское время [Minina et al., 2016b]. Важен изученный разрез урмугтэйульской формации и ее несогласные контакты с ордовикскими и девонскими гранитоидами по правобережью р. Хара-Гол, северо-западнее поселка Дзунхараа (см. рис. 5). Здесь в разрезе каменноугольных терригенных отложений наблюдаются грубозернистые, аркозовые песчаники, среди которых отмечаются угловатые обломки розовых гранитов и окатанная галька (10-15 см) мелкозернистых гранитов девонского возраста. Вверх по разрезу песчаники сменяются конглобрекчиями с хорошо окатанной галькой кислых вулканитов и реже - гранитов.

На территории Центрального Забайкалья по правому борту долины реки Чикой нижне- и среднекаменноугольные отложения изучались в пределах Чикойского (Маргинтуйского) осадочного бассейна, расположенного на юго-западных склонах Малханского хребта. Они представлены фаунистически охарактеризованными отложениями гутайской свиты ( $\left.\mathrm{C}_{1-2} \mathrm{gt}\right)$, которые распространены в бассейне р. Маргинтуй, на площади около 20 км². Литологически сходные с ними отложения закартированы также в бассейнах рек Гутай и Мостовки. Гутайская свита представлена грубокластическими отложениями прибрежно-морской фации: конгломератами, песчаниками, алевролитами, среди которых присутствуют линзообразные прослои риолитов, туфоконгломератов, туфопесчаников и силлы долеритов. Туфогенный материал установлен также в нормально-осадочных алевролитах, содержащих фауну брахиопод, двустворчатых моллюсков и мшанок [Kotlyar, Popeko, 1974]. В бассейне p. Маргинтуй отложения гутайской свиты залегают на размытой поверхности среднепалеозойских габброидов и гранитоидов и перекрываются ортинкской и тамирской свитами среднего и верхнего карбона и перми [Gordienko, 2012]. Наиболее распространенными породами гутайской свиты на данном участке являются конгломераты. В гальке присутствуют риолиты, диориты, габбро, огнейсованные граниты, аляскитовые граниты и граносиениты. Стратотипический разрез гутайской свиты расположен по р. Гутай и в пади Бенланиха, где он сложен вулканогенно-терригенными породами. Изученные вулканогенные породы гутайской сви- ты по геохимическим параметрам принадлежат толеитовой серии тыловой части АКО.

\section{3. ГЕОХИМИЧЕСКИЕ И ИЗОТОПНО-ГЕОХРОНОЛОГИЧЕСКИЕ ОСОБЕННОСТИ СТРУКТУРНО-ВЕЩЕСТВЕННЫХ КОМПЛЕКСОВ ХЭНТЕЙ-ДАУРСКОЙ СКЛАДЧАТОЙ СИСТЕМЫ}

При структурно-формационном районировании исследованной нами Хэнтей-Даурской складчатой системы широко использовался вещественный состав и возраст, прежде всего, магматических пород как главных эндогенных индикаторов для определения геодинамических условий формирования пород в древних складчатых областях. Нами установлено, что в формировании Хэнтей-Даурской структуры основную роль сыграл раскрывшийся в раннем ордовике Харагольский спрединговый океанический бассейн. Его развитие в ордовике, силуре, девоне и карбоне определило заложение зон субдукции, формирование надсубдукционного магматизма и осадконакопления в преддуговых и задуговых бассейнах возникшего Монголо-Охотского океана на окраине Сибирского континента.

Как установлено нами ранее [Gordienko et al., $2012 b]$, в пределах Харагольского прогиба выявлено присутствие трех морфологических типов магматических пород верхней части разреза океанической коры: подводных вулканических потоков и покровов массивных (компактных) и подушечных лав, сцементированных гиалокластитами, в ассоциации с кремнистыми породами, а также вытянутых вдоль разломов массивов габброидов и сближенных дайкообразных тел долеритов и габбродолеритов. Базальтоиды слагают довольно мощные (до 1000 м) и монотонные потоки, главным образом в основании разреза харинской серии. Крупная субмеридиональная полоса подушечных лав, сцементированных гиалокластитами, прослежена от верховьев реки Хара-гол до сомона Тунхэл и далее на северо-восток до Центрального Забайкалья (рис. 10).

Выше по разрезу количество лавовых потоков резко уменьшается и они постепенно замещаются терригенными породами (песчаники, алевролиты, алевропелиты) с горизонтами кварцитов и кремнистых пород (силицитов). В геохимических анализах базальтоидов не наблюдается значимой разницы между подушечными и массивными лавами. По нормативному составу вулканиты относятся в равной мере к кварц- и оливин-нормативным. По петрохимическому составу вулканиты представлены единой генетической серией нормального ряда. Исследованные метагаббро и метагаббро-долериты, входящие в состав харинской серии, относятся к слабодифференцированным породам. Содержа- 

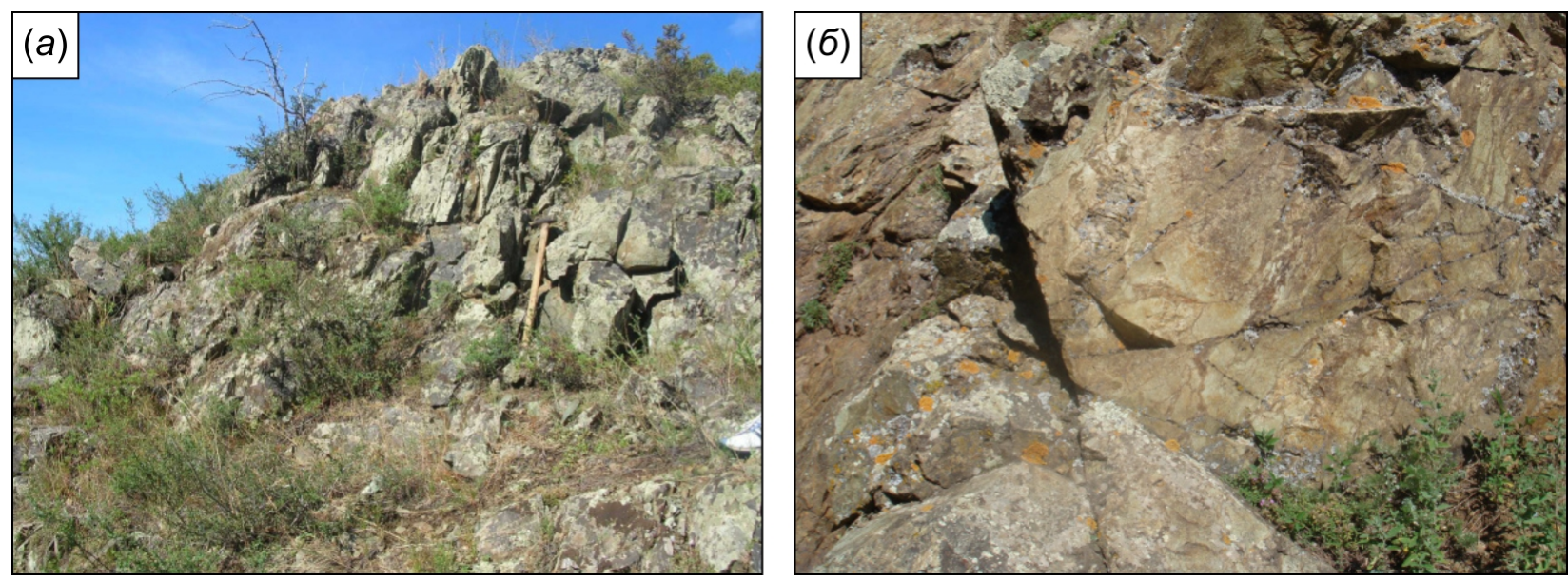

Рис. 10. Ордовикские пиллоу-лавы, сцементированные гиалокластитами (a) и дайки габбро-долеритов (б) в бассейне реки Хара-гол.

Fig. 10. Ordovician pillow lavas cemented with hyaloclastites $(a)$, and gabbro-dolerite dykes (б) in the Khara-gol River valley.

ние главных петрогенных элементов меняется незначительно. Породы относятся к низко- и умеренно-титанистым и умеренно-глиноземистым разностям, комагматичным с базальтоидами. На дискриминационной диаграмме щелочность - кремнекислотность можно видеть, что точки составов габброидов располагаются в основном поле нормального петрохимического ряда, образуя достаточно компактную область (рис. 11).

Абсолютный возраст даек габбро-долеритов и долеритов по результатам U-Pb датирования по цирконам и бадделеиту составляет $450 \pm 5,460 \pm 4$,

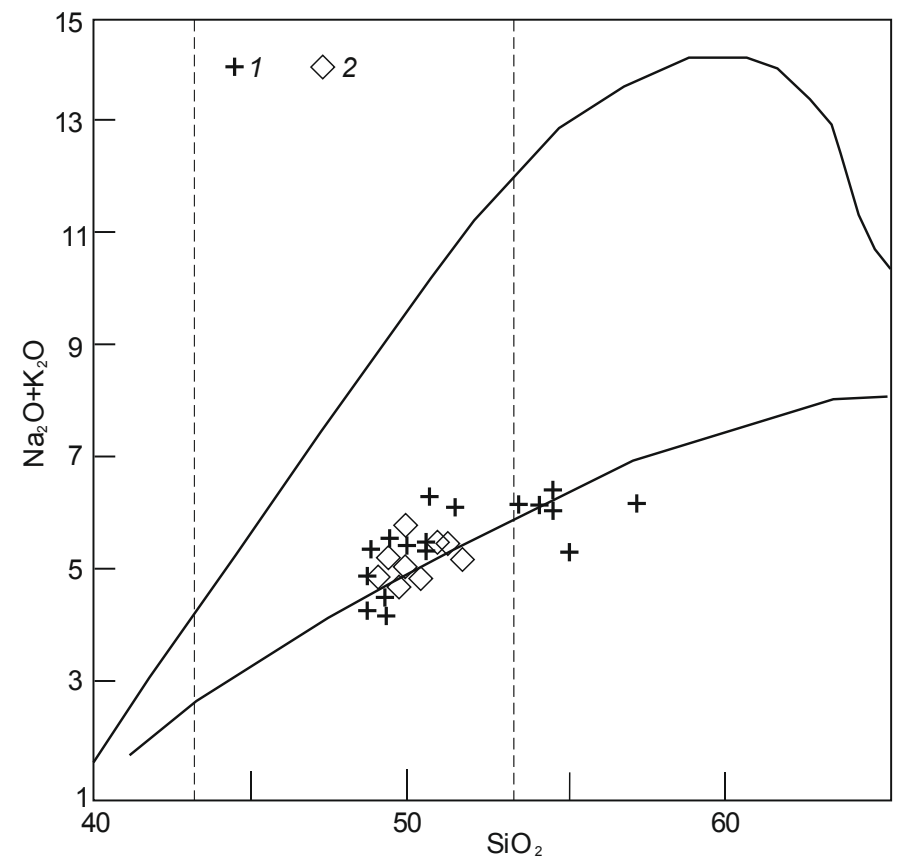

469 $\pm 8,475 \pm 7$ млн лет [Gordienko et al., 2012b]. Модельный возраст протолитов $\mathrm{TNd}(\mathrm{DM})$ габбродолеритов составляет 1270-1338 млн лет. В составе туфогенно-кварцито-песчано-сланцевой толщи обнаружены детритовые цирконы, U-Pb возраст которых колеблется от раннего кембрия до позднего архея с пиками на уровне 570-600, 870-900, и около 1850 млн лет, что указывает на преимущественно сибирские источники сноса [Kelty et al., 2008].

Для определения принадлежности изученных магматических пород харинской серии к геодина-

Рис. 11. Классификационная диаграмма щелочность кремнекислотность для магматических пород Харагольского океанического бассейна.

1 - метавулканиты; 2 - метагаббро и метагаббро-долериты.

Fig. 11. Classification diagram for alkalinity - silicic acidity of magmatic rocks of the Kharagol oceanic basin.

1 - metavolcanic rocks; 2 - metagabbro and metagabbro-dolerite. 


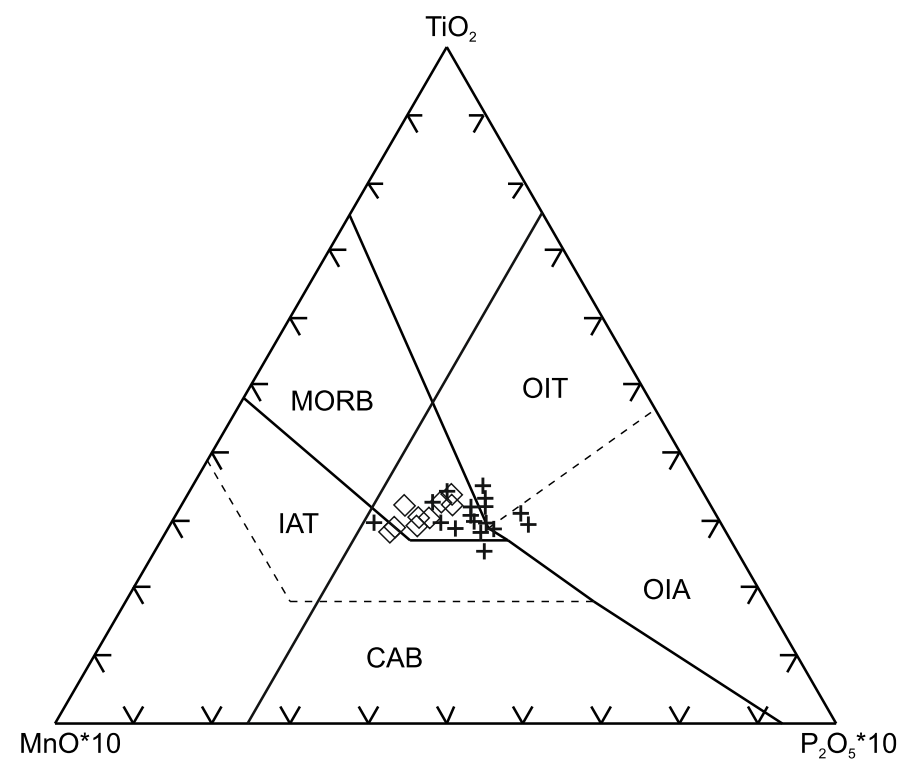

Рис. 12. Дискриминационная диаграмма [Mullen, 1983] для пород Харагольского бассейна. Усл. обозначения пород см. на рис. 11.

Fig. 12. Discriminative diagram [Mullen, 1983] for the rocks of the Kharagol basin. See the legend in Fig. 11.

мической обстановке их формирования была использована дискриминационная диаграмма Е. Маллена [Mullen, 1983]. На ней видно, что большая часть исследованных образцов, как вулканитов, так и габброидов, располагается в поле пород срединно-океанических хребтов, за исключением отдельных образцов, точки которых попадают в поле толеитов и андезитов океанических островов и островных дуг (рис. 12).

Редкоэлементный состав базальтов и габбродолеритов харинской серии указывает на их формирование в условиях спрединга. На диаграмме P3Э, нормированных хондриту [Sun, McDonugh, 1989], точки составов пород харинской серии располагаются в достаточно широком интервале по абсолютным значениям между графиками распределения РЗЭ в OIB и Е-MORB, совпадая со значениями РЗЭ в базальтах ВАВ (рис. 13). На спайдер-диаграмме РЗЭ, нормированных к примитивной мантии, спектры вулканитов, габбро и долеритов харинской серии достаточно удовлетворительно совпадают со спектрами пород спрединговых бассейнов ВАВ [Gordienko et al., 2012b].

Таким образом, анализ геохимических данных магматических пород спрединговой зоны Харагольского океанического бассейна показывает, что базальтоиды и габброиды харинской серии близки между собой по вещественному составу. Такие данные могут служить подтверждением того, что они произошли из одного субстрата и это подтвержда- ется близким модельным возрастом протолита (см. выше). Анализ диаграмм показывает, что приведенные данные не противоречат образованию исследованных пород из единой серии в условиях спредингового бассейна. Присутствие среди вулканитов гиалокластитов, кремнистых и терригенных пород еще раз свидетельствует о их образовании в водных условиях морского бассейна.

Сходство геодинамических условий формирования океанических пород было установлено также на продолжении структур Харагольского спредингового бассейна на смежной территории Восточного Забайкалья в пределах Онон-Кулиндинского, Агинского и Агуца-Кыранского бассейнов, что подтверждается сходными геохимическими и изотопно-геохронологическими данными (рис. 14).

Так, в пределах Онон-Кулиндинского океанического спредингового бассейна широко распространены метабазальты, объединяемые в составе кулиндинской и ононской свит. Спектры распределения редкоземельных элементов в них в основном соответствуют OІB. Характерны высокие концентрации $\mathrm{TiO}_{2}$ (2.40-3.86 мас. \%), Zr (244 г/т), Nb (54 г/т) и высокие значения La/Yb. Также присутствуют базальты, имеющие слабодифференцированный спектр РЗЭ, умеренный (1.14-3.37) уровень $\mathrm{La} / \mathrm{Yb}$ отношений и заметно более низкие концентрации $\mathrm{TiO}_{2}$ (1.04-2.30 мас. \%), $\mathrm{Zr}$ (67-190 г/т), Nb (22-63 г/т), что сближает их с E-MORB. Для U-Pb изотопно-геохронологических исследований использовалась проба пиллоу-лав базальтов кулиндинской свиты. U-Pb данные по цирконам метабазальтов (SHRIMP-II, г. Санкт-Петербург) показали конкордантный ордовикский $(475 \pm 8$ и $446 \pm 7$ млн лет) [Bulgatov et al., 2010] и силурийский 423.8 \pm 4.5 $440.5 \pm 4.2$ млн лет) возраст [Shivokhin et al., 2010]. Существенным является установление в базальтах кулиндинской свиты глаукофансланцевого метаморфизма в условиях повышенных давлений с образованием кроссита, указывающих на субдукционные процессы в Онон-Кулиндинском прогибе [Dobretsov et al., 1988]. Важным геодинамическим индикатором является ордовик-силурийский Цугольский расслоенный габбро-плагиогранитный массив с U-Pb изотопным возрастом $448.2 \pm 9.1$ и 436 \pm 4 млн лет [Ruzhentsev, Nekrasov, 2009]. Все эти события хорошо увязываются с развитием Харагольского спредингового бассейна в пределах Хэнтей-Даурской системы МОСП.

В Агинском океаническом бассейне в основании разреза вскрывается девонская усть-борзинская осадочно-вулканогенная свита с базальтами N- и E-MORB, связанная с формированием спрединговых зон Монголо-Охотского океана. Спектры распределения редкоземельных элементов в них также в основном соответствуют N-MORB и E-MORB 


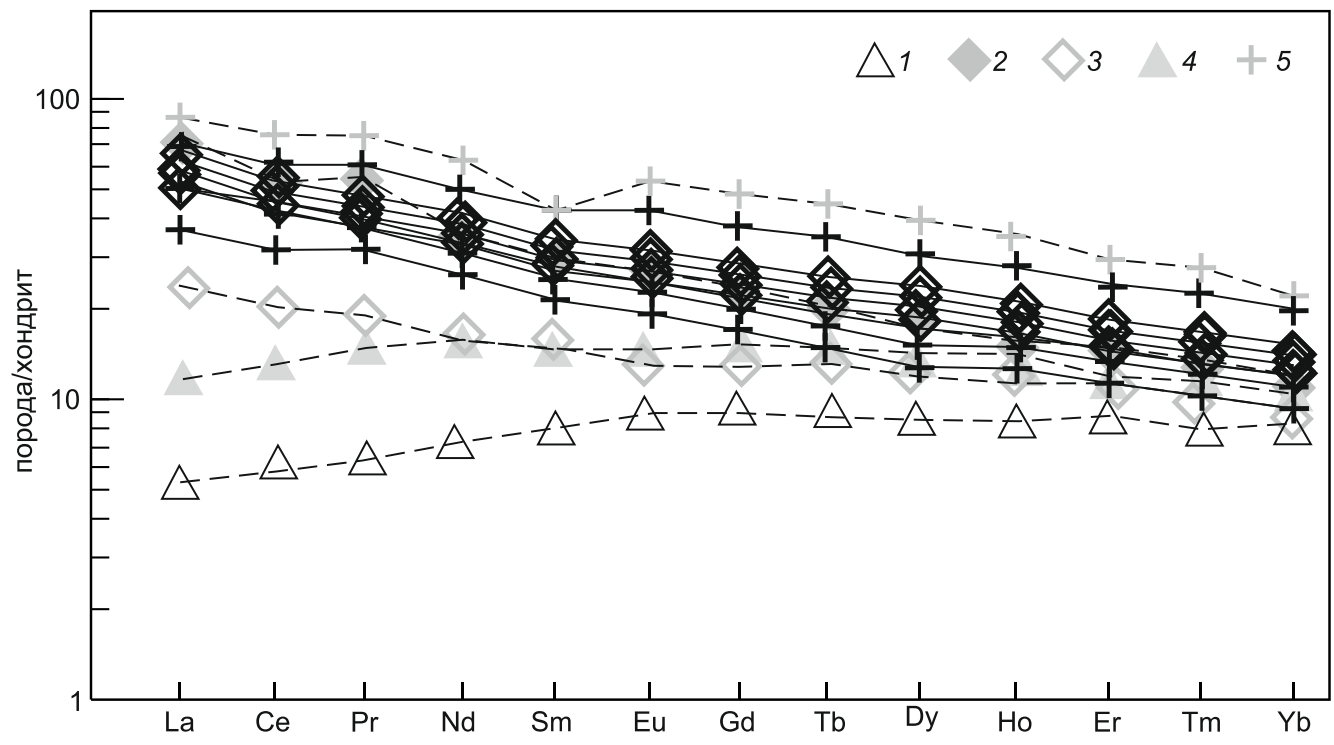

Рис. 13. Распределение РЗЭ, нормированных по хондриту С1, в магматических породах Харагольского бассейна [Sun, McDonough, 1989].

1 - IAB [Tamura et al., 2005]; 2 - BAB [Sun, McDonough, 1989]; 3 - E-MORB [Sun, McDonough, 1989]; 4 - N-MORB [Sun, McDonough, 1989]; 5 - OIB [Sun, McDonough, 1989]. Остальные усл. обозн. см. на рис. 11.

Fig. 13. REE distribution normalized for chondrite C1 in the magmatic rocks of the Kharagol basin [Sun, McDonough, 1989]. 1 - IAB [Tamura et al., 2005]; 2 - BAB [Sun, McDonough, 1989]; 3 - E-MORB [Sun, McDonough, 1989]; 4 - N-MORB [Sun, McDonough, 1989]; 5 - OIB [Sun, McDonough, 1989]. See also the legend in Fig. 11.

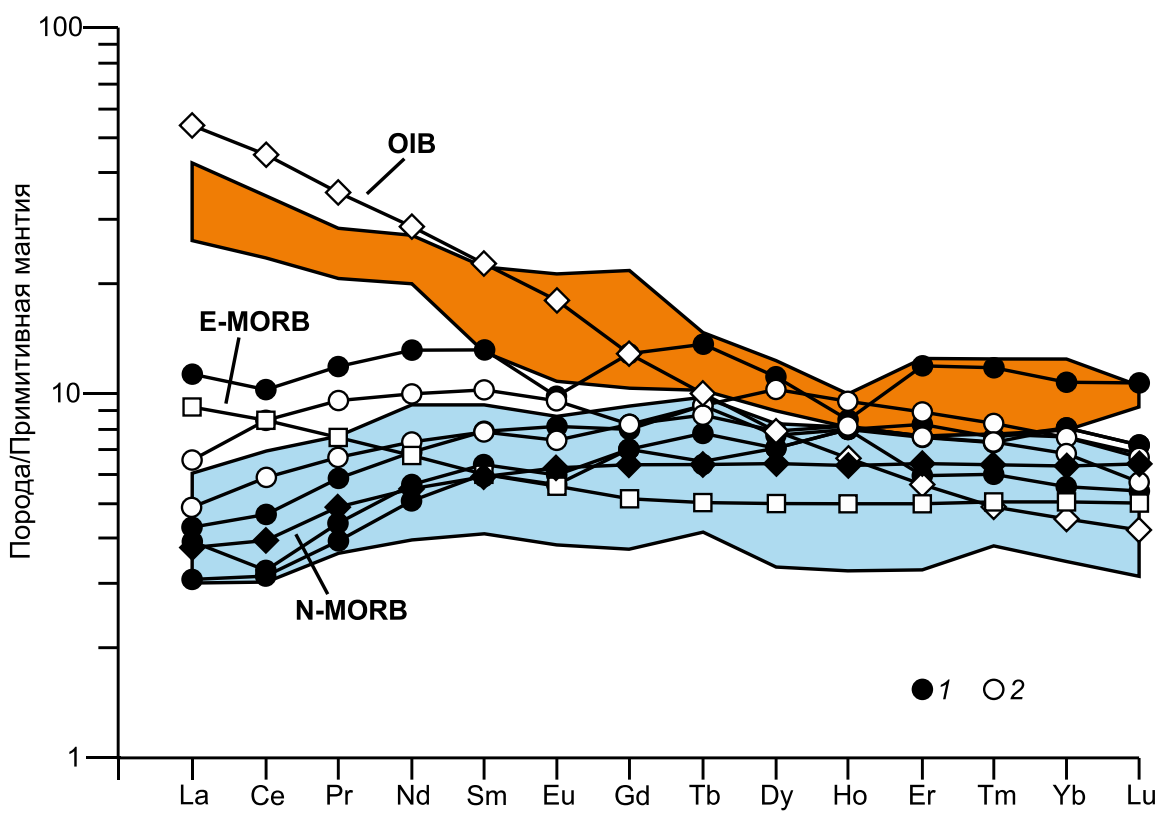

Рис. 14. Нормированные к примитивной мантии содержания РЗЭ в базальтах океанических прогибов Восточного Забайкалья (по [Bulgatov et al., 2010] с дополнениями).

1-2 - метабазальты харинской, ононской и куналейской (1), кулиндинской и устьборзинской (2) свит. Оранжевый цвет - метавулканиты Харагольского, Куналейского, Агуца-Кыранского, Онон-Кулиндинского прогибов; голубой цвет - метавулканиты и габброиды Агинского и Восточно-Хэнтейского прогибов.

Fig. 14. REE content (normalized to the primitive mantle) of the basalts in the oceanic troughs of the Eastern Transbaikalia (after [Bulgatov et al., 2010], including additional data).

1-2 - metabasalts of the Kharin, Onon and Kunalei (1), Kulinda and Ust-Borzya (2) suites. Orange - metavolcanites of Kharagol, Kunalei, Agutsa-Kyran, and Onon-Kulinda troughs; blue - metavolcanites and gabbroids of the Aga and East Hentei troughs. 
(см. рис. 14). Аналогичная ситуация наблюдается в развитии Агуца-Кыранского океанического бассейна.

Проведенные исследования силур-девонских метабазальтов кулиндинской, ононской, агуцинской и усть-борзинской свит в пограничной зоне Восточного Забайкалья и на территории Восточной Монголии показали, что вулканические породы этих свит близки по своему геохимическому составу. По своим геохимическим характеристикам изученные породы принадлежат базальтам срединноокеанических хребтов (типа N-MORB и E-MORB). B современном залегании они представляют собой пакет совмещенных тектонических пластин различного состава, сложенных фрагментами осадочных турбидитовых толщ дистальной фации, а также фрагментами вулканогенной части океанической коры [Medvedev et al., 2007; Gordienko et al., $2012 b]$.

Выделение в пределах Хэнтей-Даурской структуры силур-девонских островодужных ассоциаций пород также хорошо подтверждается геохимическими и изотопно-геохронологическими данными. Так, в Еро-Дзунмод-Лунской островодужной системе, в ее фронтальной части, сформировалась цепочка девонских вулканотектонических структур (Дзунмодская, Мунгуликская, Ялбаг-Ерогольская, Харинская), сложенных в нижней части вулканическими сериями пород андезит-дацит-риолитового состава. Позднее их формировались комагматичные им средне- и верхнедевонские габброиды и гранитоиды, широко распространенные во всей выделенной нами островодужной системе и за ее пределами, в основном на каледонской окраине Центрально-Монгольского микроконтинента.

На геохимических спайдер-диаграммах [Gordienko et al., 2012b] девонские вулканиты, габброиды и гранитоиды образуют слабодифференцированную серию с минимумом по таким элементам, как $\mathrm{Nb}$, $\mathrm{Zr}, \mathrm{Ti}$, и максимумом для $\mathrm{Sr}$, что характерно для пород островодужных серий или активных континентальных окраин. Петрохимические особенности девонских вулканогенных пород рассматриваемой территории позволяют отнести их к дифференцированной андезит-дацит-риолитовой лейкократовой серии с нормальной и повышенной щелочностью. Концентрация $\mathrm{SiO}_{2}$ в них колеблется от 65 (в дацитах) до 76 мас. \% (в стекловатых трахириолитах). Низкое содержание глинозема, окиси железа, магния, кальция, часто повышенное содержание щелочей при преобладании калия над натрием указывают на отчетливый щелочно-салический профиль химизма вулканогенных пород. Более молодые габброиды и гранитоиды средне- и верхнедевонского возраста по геохимическим параметрам также относятся к островодужным образованиям.
Так, например, спектр распределения РЗЭ в габброноритах крупного (около 20 км²) Бальджгольского массива соответствует спектру островодужных толеитов. В них наблюдаются минимумы по таким характеристическим элементам, как $\mathrm{Nb}, \mathrm{Zr}, \mathrm{Ti}$, и максимум для $\mathrm{Sr}$, что характерно для пород островодужных серий. ${ }^{40} \mathrm{Ar} /{ }^{39} \mathrm{Ar}$ изотопный возраст габбро-норитов $388.7 \pm 5.6,372.0 \pm 5.5,364.2 \pm 9.9$ млн лет. Позднее их образовались массивы позднедевонских известково-щелочных гранитоидов (395405 млн лет), которые с конгломератами в основании перекрываются ранне- и среднекаменноугольными отложениями [Gordienko et al., 2012a].

Отчетливая геохимическая специфика характеризует Эрдэни-Адацагскую энсиматическую островодужную систему, закартированную на территории Центральной Монголии восточнее УланБатора. Надсубдукционный комплекс адацагских офиолитов состоит из серпентинитового меланжа, расслоенной габброидной серии, долеритовых даек и лав базальтового, андезибазальтового состава. Последние имеют типичный толеитовый тренд дифференциации с увеличением железистости. Базальты характеризуются повышенным содержанием $\mathrm{MgO}$ (до 12.8 мас. \%), $\mathrm{Cr}$, Ni и низкими концентрациями $\mathrm{TiO}_{2}, \mathrm{P}_{2} \mathrm{O}_{5}$ и щелочей. По форме кривых и уровню содержаний РЗЭ базальты и андезибазальты соответствуют толеитам островных дуг. Это подтверждается отчетливыми минимумами по $\mathrm{Nb}$, $\mathrm{Ta}, \mathrm{Zr}, \mathrm{Hf}, \mathrm{Ti}$. Аналогичное распределение состава РЗЭ имеют долериты и габброиды, что позволяет объединить их в составе единого офиолитового комплекса [Gornova et al., 2004].

Полученные нами распределения РЗЭ эрдэнэкеруленских офиолитов, нормированных по хондриту [Sun, McDonugh, 1989], показывают, что образование пород могло происходить в различных геодинамических обстановках. Так, базальты и габбро могли формироваться в условиях срединноокеанического хребта либо в условиях задугового бассейна, а пироксениты - в условиях островной дуги. Это также подтверждается данными распределения наиболее характеристических элементов, нормированных к примитивной мантии, точки составов базальтов располагаются в достаточно широком интервале по абсолютным значениям между графиками распределения Р3Э в OIB и E-MORB. Beроятнее всего, изученный разрез представляет собой коллаж из магматических пород различных геодинамических обстановок. Наличие кремнистоуглистых сланцев в ассоциации с серпентинитами подтверждает их образование в глубоководных условиях.

В каменноугольном периоде формировались обширные бассейны седиментации, как на девонской океанической коре, так и на окружающих кон- 
тинентальных поднятиях. В это время существовали глубоководные и мелководные моря и лагунные бассейны, где, наряду с обычным осадконакоплением терригенно-молассовых толщ, возникали рифтовые прогибы с вулканогенным и осадочновулканогенным породообразованием как в подводных, так и в наземных условиях. Такие отложения отчетливо фиксируются, например, в Даурском (ингодинская серия) и Чикойском (гутайская свита) прогибах Центрального Забайкалья. Изученные вулканогенные породы гутайской свиты Чикойского прогиба (базальты, андезибазальты, андезиты и риолиты) по соотношению $\mathrm{SiO}_{2}-\left(\mathrm{Na}_{2} \mathrm{O}+\mathrm{K}_{2} \mathrm{O}\right)$ относятся к известково-щелочной серии, а по соотношению $\mathrm{SiO}_{2}-\mathrm{K}_{2} \mathrm{O}$ - к умеренно- и высококалиевым. По величине отношения $\mathrm{Na}_{2} \mathrm{O} / \mathrm{K}_{2} \mathrm{O}$ вулканиты обладают калиево-натриевой специализацией (0.97-3.89), а по содержанию глинозема принадлежат к высокоглиноземистым разностям $\mathrm{al}^{\prime}=1.02-$ 2.33). По соотношению содержаний $\mathrm{SiO}_{2}-\mathrm{FeO} / \mathrm{MgO}$ все точки составов вулканитов лежат в поле толеитовой серии. С увеличением кремнекислотности от базальтов до риолитов в вулканитах гутайской свиты закономерно падают концентрации глинозема, железа, магния и кальция, а концентрация щелочей возрастает. По этим параметрам вулканиты совместно с осадочными породами, по-видимому, формировались в задуговых прогибах.

\section{4. ГЕОДИНАМИЧЕСКАЯ МОДЕЛЬ ФОРМИРОВАНИЯ ХЭНТЕЙ-ДАУРСКОЙ СКЛАДЧАТОЙ СИСТЕМЫ МОНГОЛО-ОХОТСКОГО ОРОГЕННОГО ПОЯСА}

В результате проведенных структурно-геологических, геохимических, изотопно-геохронологических и биостратиграфических исследований в пределах Хэнтей-Даурской складчатой системы Монголо-Охотского пояса предложена новая модель геодинамического развития изученной системы. При структурно-формационном районировании территории нами выделено шесть структурно-формационных зон, сложенных рядом индикаторных структурно-вещественных комплексов различной геодинамической природы. Среди них присутствуют комплексы обширных океанических бассейнов с глубоководной седиментацией и подводным вулканизмом, а также островодужные системы энсиалического и энсиматического типа на активных окраинах этих бассейнов и древних тектонических структур (микроконтинентов) - отторженцев Сибирского континента (см. рис. 2).

Выделяется два главных этапа формирования структуры Хэнтей-Даурской системы: позднекаледонский и раннегерцинский, а также завершающий позднегерцинский (рис. 15).
На позднекаледонском этапе (в позднем кембрии, ордовике и раннем силуре) произошли главные события в формировании Хэнтей-Даурской складчатой системы. Во-первых, к этому времени на окраине Сибирского палеоконтинента в результате раннекаледонских аккреционных процессов в Центрально-Азиатском складчатом поясе образовался неопротерозойско-раннекембрийский Центрально-Монгольский микроконтинент [Tomurtogoo, 2005]. Во-вторых, именно на его окраине по зоне трансрегиональных глубинных разломов, связанных с Монголо-Охотским линеаментом, произошло заложение и образование узкого спредингового бассейна красноморского типа, который послужил началом развития Монголо-Охотского океана. В последующем, в раннем - среднем ордовике (470-450 млн лет), здесь образовалась спрединговая зона (рифтовая долина), в которой началось формирование океанической коры с глубоководным (пелагическим) осадконакоплением и мантийным магматизмом. В настоящее время в этой зоне вскрывается только верхняя часть офиолитового комплекса (расслоенное и кумулятивное габбро, дайковый комплекс, пиллоу-лавы базальтов Nи E-MORB типа и кремнистые отложения). По геохимическим данным этот магматизм и кремнистое осадконакопление могли быть связаны с формированием срединно-океанических хребтов [Gordienko et al., 2012a, 2012b].

В результате вышеназванных процессов сформировался Харагольский океанический спрединговый бассейн и началась субдукция океанической коры под континентальные окраины ЦентральноМонгольского, а также Идэрмэг-Эрэндава-Керуленского микроконтинента. Это привело к образованию ордовикско-раннесилурийского островодужного магматизма и формированию океанических бассейнов на продолжении Харагольской спрединговой зоны, прежде всего в Забайкалье, где одновременно образовались подобные бассейны седиментации (Куналейский, Онон-Кулиндинский, Агуца-Кыранский и другие), а также задуговые раннесилурийские мелководные осадочные бассейны на микроконтинентах. В островных дугах этого этапа (Дархан-Малханской и Модохудукской) проявился надсубдукционный энсиалический вулканизм и гранитообразование.

В пределах Дархан-Малханской дуги в среднем верхнем кембрии и раннем - среднем ордовике образовались локальные островодужные комплексы (например, реликтовая Ульдзутуйская дуга в Еравне с U-Pb среднеордовикским возрастом вулканитов $470.4 \pm 3.8$ и $466.1 \pm 3.6$ млн лет), крупные массивы габброидов ингодинского $(440 \pm 20$ млн лет) и гранитоидов малханского $(427 \pm 3$ и $472 \pm 2$ млн лет) комплекса коллизионного и островодужного типа 

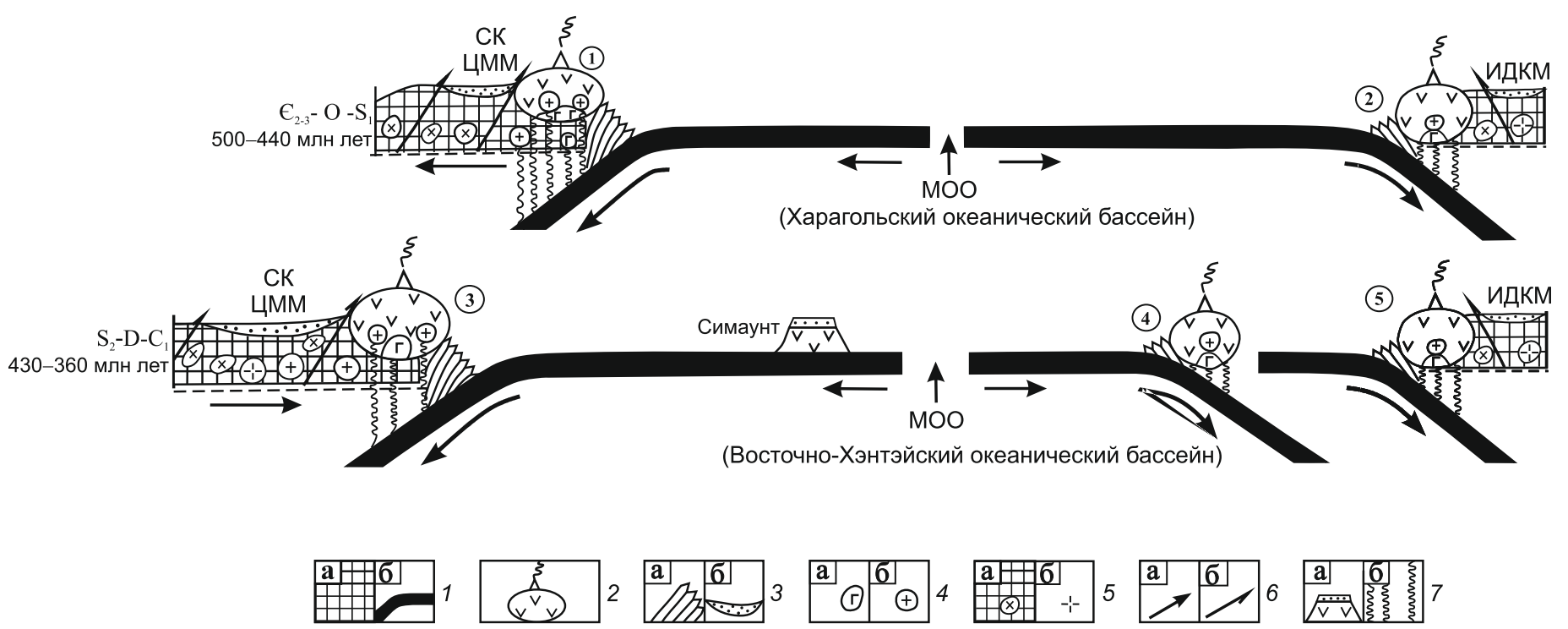

Рис. 15. Реконструкция геодинамического развития Хэнтей-Даурской системы Монголо-Охотского складчатого пояса в раннем и среднем палеозое.

1 - континентальная (а) и океаническая (б) кора; 2 - островные дуги (цифры в кружочках): 1 - Дархан-Малханская, 2 - Модохундукская, 3 - Еро-Дзунмод-Лунская, 4 - Эрдэни-Адацагская, 5 - Онон-Норовлинская; 3 - аккреционные призмы в преддуговых (а) и наложенные прогибы в задуговых бассейнах (б); 4 - островодужные габброиды (а) и гранитоиды (б); 5 - коллизионные (а) и внутриплитные (б) гранитоиды; 6 - направления движений океанических плит и плюмового магматизма в спрединговых зонах океанов (а) и надвиговых перемещений на микроконтинентах (б); 7 - симаунт (а) и потоки флюидов (б). СК - Сибирский континент; МОО - Монголо-Охотский океан; ЦММ - Центрально-Монгольский микроконтинент; ИДКМ - Идэрмэг-Эрэндава-Керуленский микроконтинент.

Fig. 15. Reconstruction of the geodynamic development of the Hentei-Dauria system of the Mongolia-Okhotsk fold belt in the Early and Middle Paleozoic.

1 - continental (a) and oceanic (б) crust; 2 - island arcs (numbers in circles): 1 - Darkhan-Malkhan, 2 - Modokhunduk, 3 - Ero-DzunmodLun, 4 - Erdeni-Adatsag, 5 - Onon-Norovlin; 3 - accretionary prisms in pre-arc (a) and superimposed troughs in back-arc basins (б); 4 - island arc gabbroids (a) and granitoids (б); 5 - collision (a) and intraplate (б) granitoids; 6 - directions of oceanic plate movements and plume magmatism in spreading zones of the oceans (a) and thrust displacements on microcontinents (б); 7 - seamount (a) and flows of fluids (б). СК - Siberian continent; MOО - Mongolia-Okhotsk ocean; ЦММ - Central Mongolian microcontinent; ИДКМ - IdermagErendava-Kerulen microcontinent.

в Центральном Забайкалье [Ruzhentsev et al., 2012; Gordienko et al., 2012a]. Подобные образования широко распространены на каледонских окраинах Центрально-Монгольского микроконтинента, где они формируют ряд крупных массивов габброидов (например, Хутэльский - 569-570 млн лет) [Elbaev et al., 2017] и гранитоидов (Борогольский массив от $463.0 \pm 6.7$ до 471.4 \pm 2.7 млн лет) [Altanzul et al., 2018], а также ряд массивов по Шаргын-Голу, вдоль Орхон-Хилокского и Баянгол-Чикойского глубинных разломов.

На раннекаледонской окраине Идэрмэг-Эрэндава-Керуленского микроконтинента в раннем ордовике также возникла зона субдукции, которая контролировала надсубдукционный ордовикский вулканизм и формирование габброидов и гранитоидов дифференцированного модохудукского интрузивного комплекса (см. рис. 14). В крупных массивах палеозойских гранитоидов этого комплекса присутствуют габбро и граниты различных гене- тических типов (коллизионные, островодужные и внутриплитные). В этом отношении они плохо изучены. Возрастное положение комплекса определяется прорыванием нижнеордовикских осадочновулканогенных отложений и перекрытием задуговыми отложениями раннего силура и среднего верхнего девона [Marinov, 1973b]. Подобная ассоциация пород диорит-гранодиорит-гранитного состава с раннеордовикским U-Pb возрастом $(488 \pm 5$ млн лет) выделена в смежных районах Идэрмэг-АргуноМамынского террейна [Sorokin, Kudryashov, 2017].

В раннем силуре на юго-востоке (в современных координатах) Харагольского океанического спредингового бассейна проявилась мощная лавинная седиментация с образованием флишоидной толщи мощностью более 2000 м, которая привела, по-видимому, к закупорке и прекращению магматической деятельности. Однако на этом мантийные процессы в спрединговой зоне не закончились, они продолжались, и это привело в конце силура - на- 
чале девона к заложению и (или) продолжению развития нового спредингового океанического бассейна, названного нами Восточно-Хэнтейским.

На раннегерцинском этапе $\left(\mathrm{S}_{2}, \mathrm{D}, \mathrm{C}_{1}\right)$ спрединговый магматизм и глубинное осадконакопление были сосредоточены в Улан-Баторском, Агинском и Агуца-Кыранском океанических прогибах Восточно-Хэнтейского спредингового бассейна. Так, в Улан-Баторском прогибе глубоководная седиментация с образованием радиоляриевых кремнистых пород раннего - среднего девона происходила одновременно с излияниями океанических базальтов N- и E-MORB типа, а также формированием в зонах трансформных разломов океанических островов (симаунтов и гайотов) с ОІВ базальтами, которые в дальнейшем перемещались на океанических плитах в зону субдукции Ерогол-Дзунмод-Лунской островодужной системы, где в настоящее время фиксируются в аккреционных призмах среднего верхнего девона. Появление океанических островов, сложенных субщелочными базальтами ОІВ и «шапками» известняков с девонскими конодонтами, образование радиоляриевых кремней, гиалокластитов, излияние толеитовых базальтов, отсутствие среди кремнистых отложений терригенного материала указывают на широкое раскрытие и длительное существование (около 70 млн лет) девонского океанического бассейна и его связь с плюмовым магматизмом. Субдукционно-аккреционные процессы на окраине этого гигантского океанического бассейна сыграли важную роль в геологической эволюции Монголо-Охотского складчатого пояса [Kurihara et al, 2006; Ruppen et al., 2014].

В пределах названной островодужной системы в конце силура и раннем девоне продолжал развиваться островодужный вулканизм и формировались островодужные габброиды и гранитоиды. В это время во фронтальной части дуги возникла цепочка крупных вулканотектонических структур (Дзунмодская, Мунгуликская, Ялбаг-Ерогольская, Харинская и другие), сложенных андезит-дацитриолитовыми ассоциациями пород, сопоставимых с Северо-Хангайской зоной девонского островодужного вулканизма [Gordienko, 1987]. Девонские вулканиты, габброиды и гранитоиды образуют слабодифференцированную серию с минимумом по таким элементам, как $\mathrm{Nb}, \mathrm{Zr}, \mathrm{Ti}$, и максимумом для $\mathrm{Sr}$, что характерно для пород островодужных серий или активных континентальных окраин. Активный интрузивный магматизм, комагматичный островодужному вулканизму, проявился как в нижнем среднем девоне, так и в конце девона. Это подтверждается изотопно-геохронологическими данными $\left({ }^{40} \mathrm{Ar}-{ }^{39} \mathrm{Ar}\right.$ возраст габброидов - 388, 372, 364 млн лет и U-Pb возраст гранитоидов - 405 и 395 млн лет). В тыловой части островодужной системы образовались задуговые бассейны морского осадконакопления среднего - позднего девона и раннего карбона, которые перекрывают островодужные магматические образования с конгломератами в основании.

Возникшая в девоне спрединговая зона, фиксируемая Восточно-Хэнтейским океаническим бассейном Монголо-Охотского океана, привела к формированию Эрдэни-Адацагской и Онон-Норовлинской островодужных систем. Эрдэни-Адацагская островная дуга энсиматического типа образовалась в результате субдукции и плавления океанической плиты Восточно-Хэнтейского спредингового бассейна. Адацагские офиолиты по петрологогеохимическим параметрам относятся к надсубдукционным образованиям. Они состоят из серпентинитового меланжа, кумулятивной и расслоенной габброидной серии, долеритовых даек, кремнистых пород и пиллоу-лав базальтового, андезибазальтового состава. Последние имеют типичный толеитовый тренд дифференциации. По уровню содержаний РЗЭ базальты и андезибазальты соответствуют толеитам островных дуг. Это подтверждается отчетливыми минимумами по $\mathrm{Nb}$, $\mathrm{Ta}, \mathrm{Zr}, \mathrm{Hf}, \mathrm{Ti}$ и максимумом по Sr [Gornova et al., 2004; Gordienko, Metelkin, 2016]. Подобные геохимические характеристики имеют эрдэнэ-керуленские офиолиты, находящиеся в одной полосе развития Адацаг-Ононского глубинного разлома.

По распределению РЗЭ, нормированных по хондриту, их образование могло происходить в различных геодинамических обстановках. Базальты и габбро могли формироваться в условиях срединноокеанического хребта либо в условиях задугового бассейна, а пироксениты попадают в поле островодужных образований.

Большой интерес представляет выделенная нами на реконструкциях девонского периода ОнонНоровлинская островодужная система (см. рис. 14). Мы связываем ее также с зоной субдукции Восточно-Хэнтейского спредингового океанического бассейна как залива Монголо-Охотского океана. Эта островная дуга непосредственно связана с субдукцией океанической коры под Идэрмэг-ЭрэндаваКеруленский микроконтинент.

Вулканоплутоническая ассоциация Норовлинской ВТС подробно была изучена нами и связывалась с девонским континентальным рифтогенезом [Gordienko, 1987]. Впервые формирование этих пород стал связывать с островодужным магматизмом Ю.А. Зорин с соавторами [Zorin et al., 1997], который выделил на своих реконструкциях Ононскую островную дугу девонского возраста. В настоящее время для выделения такой энсиалической дуги имеются различные данные. Состав и возраст вулканических и интрузивных пород хорошо соотно- 
сятся с Ерогол-Дзунмод-Лунской островодужной системой. Породы Онон-Норовлинской островной дуги также перекрываются средне-верхнедевонской терригенной молассой Хардзаныйской серии и салхитской толщей среднего карбона. По вещественному составу данная островная дуга коррелирует с изученными девонскими островодужными комплексами Олдойского и Мамынского террейнов Монголо-Охотского складчатого пояса [Sorokin et al., 2015; Sorokin, Kudryashov, 2015].

На позднегерцинском завершающем этапе (в карбоне и перми) на границах Сибирского континента и Монголо-Охотского океана еще продолжали активно развиваться субдукционные и аккреционноколлизионные события, ставшие финальными для Монголо-Охотского океана и приведшие к формированию на его месте Монголо-Охотского складчатого пояса. Они проявились во всех изученных структурно-формационных зонах и занимали длительный промежуток времени. В это время активно закрывался Солонкерский океан, который разделял Северо-Китайскую окраину и континентальные массивы Южной Монголии, включая фрагменты Монголо-Охотского складчатого пояса. Индикаторами этих коллизионных и внутриплитных событий могут быть позднепалеозойские гранитоидные батолиты Хангая, Хэнтея, Западного Забайкаля и Южного Приаргунья с возрастом 325-275 млн лет [Yarmolyuk et al., 2013; Tsygankov et al., 2017].

Собственно закрытие Монголо-Охотского океана и формирование современной структуры МоСП в основном отвечают киммерийскому тектоническому этапу геологической истории при определяющей роли сдвигов. Орогенез постепенно продвигался с запада на восток, начавшись в западной части пояса в конце карбона - ранней перми (Хангай, Западное Забайкалье), продолжался в середине юры (Восточное Забайкалье) и был завершен на востоке (Приморье) только в раннем мелу.

\section{5. ЗАКЛЮЧЕНИЕ}

В результате проведенных структурно-геологических, петролого-геохимических, геохронологических и биостратиграфических исследований установлено, что палеозойская Хэнтей-Даурская складчатая система Монголо-Охотского складчатого, или орогенного, пояса сложена главным образом тремя разновозрастными ассоциациями пород, связанными с заложением и развитием океанических бассейнов и островодужных континентальных окраин Монголо-Охотского океана в течение трех главных этапов.

1. Позднекаледонский (ордовикско-раннесилурийский) этап. В результате межконтинентального рифтогенеза произошло заложение обширного Харагольско-Куналей-Онон-Кулиндинского океанического спредингового бассейна и формирование в его пределах глубоководных кремнистых отложений, излияние пиллоу-лав базальтов и андезибазальтов, образование расслоенных и кумулятивных габбро, даек габбро-долеритов на океанической коре, а также зон субдукции с островодужным магматизмом. Данный океанический бассейн, представлявший начальную стадию развития МонголоОхотского океана, существовал с позднего кембрия до раннего силура, с активной фазой океанического и субдукционного магматизма в течение 35 млн лет (от 475 до 440 млн лет).

2. Раннегерцинский (позднесилурийско-девонский) этап. После небольшого перерыва вновь произошло заложение новых зон спрединга и субдукции и формирование на южных границах (в современных координатах) Сибирского континента и окружающих его каледонских микроконтинентов Восточно-Хэнтей-Агинского спредингового океанического бассейна с островодужными окраинами. Океанический бассейн являлся, по существу, гигантским заливом Палеопацифики с внутриконтинентальным океаническим магматизмом, связанным с мантийными плюмами. Этот океанический бассейн был наиболее активным в девонский период в течение почти 70 млн лет (от 420 до 360 млн лет).

3. Позднегерцинский (каменноугольно-пермский) этап. Завершается образование крупных задуговых осадочных бассейнов, формирование аккреционных призм и сшивающих внутриплитных магматических комплексов во всех структурах Хэнтей-Даурской складчатой системы. Считается, что ширина Монголо-Охотского океана на рубеже перми и триаса могла достигать еще 2000 км [Kravchinsky et al., 2002]. Закрытие Монголо-Охотского океана и окончательное формирование Монголо-Охотского складчатого пояса произошло в средней юре в результате аккреционно-коллизионных и динамометаморфических процессов, связанных со столкновением континентов Сибири и Северного Китая. Однако тектонические движения и магматизм пояса продолжались до конца юры и сменились позднемезозойским рифтогенезом и формированием гранитогнейсовых куполов, которые обнаружены не только в Цетральном Забайкалье [Sklyarov et al., 1994], но и за его пределами (например, на Селенгино-Становом выступе и Эрэндабанском поднятии Восточной Монголии).

Полученные данные подтверждают представление о том, что Хэнтей-Даурская складчатая система сформировалась на активной окраине Сибирского континента и Монголо-Охотского океана. На осно- 
ве этих данных разработана комплексная модель геодинамического развития Хэнтей-Даурской складчатой системы Монголо-Охотского орогенного пояса от заложения океанических спрединговых бассейнов и протяженных активных островодужных окраин Монголо-Охотского океана до окончания островодужно-океанической стадии с формированием крупного аккреционно-коллизионного орогена.

\section{6. БЛАГОДАРНОСТИ}

Авторы выражают признательность и благодарность действительному члену МАН О. Томуртогоо и академику РАН В.В. Ярмолюку за конструктивные замечания, а также М.Ш. Бардиной и А.А. Каленых за техническую помощь в оформлении статьи. Работа выполнена при поддержке РФФИ (проект № 16-55-44008 Монг_а).

\section{7. ЛИTEPATУPA / REFERENCES}

Altanzul Ch., Oyuungerel S., Zhargal L., Lee I., Kim Y., Khasmaral T., 2018. Study of magma rock ages in Boroo-Zuunmod. Explorer (Khaiguulchin) 59, 211-232 (in Mongolian) [Алтанзул Ч., Оюунгэрэл С., Жаргал Л., Lee I., Kim Y., Хасмарал T., 2018. Бороо-Зуунмодны дуурэгт тархсан магмын чулуулгийн унэмлэхуй насны судалгаа // Хайгуулчин. № 59. Х. 211-232].

Amantov V.A., 1975. Tectonics and Formations of Transbaikalia and Northern Mongolia. Nedra, Leningrad, 224 p. (in Russian) [Амантов В.A. Тектоника и формации Забайкалья и Северной Монголии. Л.: Недра, 1975. 224 с.].

Amantov V.A., Blagonravov V.A., Borzakovsky Yu.A., Durante M.V., Zonenshain L.P., Louvsandanzan B., Matrosov P.S., Suetenko O.D., Filippova I.B., Khasin R.A., 1970. The main features of the Paleozoic stratigraphy of the Mongolian People's Republic. In: N.A. Marinov (Ed.), Stratigraphy and Tectonics of the Mongolian People's Republic. Nauka, Moscow, p. 8-64 (in Russian) [Амантов В.А., Благонравов В.А., Борзаковский Ю.А., Дуранте М.В., Зоненшайн Л.П., Лувсанданзан Б., Матросов П.С., Суетенко О.Д., Филиппова И.Б., Хасин Р.А. Основные черты стратиграфии палеозоя Монгольской Народной Республики // Стратиграфия и тектоника Монгольской Народной Республики / Ред. Н.А. Маринов. М.: Наука, 1970. С. 8-64].

Anashkina K.K., Butin K.S., Enikeev F.I. et al., 1997. Geological Structure of the Chita Region. Explanatory Note to the Geological Map of Scale 1: 500000. Eds. I.G. Rutshtein, N.N. Chaban. Chitageolsiemka, Chita, 239 p. (in Russian) [Анашкина К.К., Бутин К.С., Еникеев Ф.И. и др. Геологическое строение Читинской области. Объяснительная записка к геологической карте масштаба 1:500000 / Ред. И.Г. Рутштейн, Н.Н. Чабан. Чита: ГГУП «Читагеолсъемка», 1997. 239 с.].

Badarch G., Cunningham W.D., Windley B.F., 2002. A new terrane subdivision for Mongolia: implications for the Phanerozoic crustal growth of Central Asia. Journal of Asian Earth Sciences 21 (1), 87-110. https://doi.org/10.1016/ S1367-9120(02)00017-2.

Belichenko V.G., Sklyarov E.V., Dobretsov N.L., Tomurtogoo O., 1994. Geodynamic map of the Paleoasian Ocean. Eastern segment. Geologiya i Geofizika (Russian Geology and Geophysics) 35 (7-8), 29-40 (in Russian) [Беличенко В.Г., Скляров Е.В., Добрецов Н.Л., Томуртогоо О. Геодинамическая карта Палеоазиатского океана. Восточный сегмент // Геология и геофизика. 1994. Т. 35. № 7-8. С. 29-40].

Borisov V.G., 1972. New data on the stratigraphy of the Upper Proterozoic - Lower Paleozoic in the western part of Central Transbaikalia. In: Notes of the Transbaikalian Branch of the USSR Geographical Society. Issue 75. Transbaikalian Branch of the USSR Geographical Society, Chita, p. 3-5 (in Russian) [Борисов В.Г. Новые данные по стратиграфии вехнего протерозоя - нижнего палеозоя западной части Центрального Забайкалья // Записки Забайкальского филиала Географического общества СССР. Вып. 75. Чита: Забайкальский филиал географического общества СССР, 1972. С. 3-5]

Bulgatov A.N., Gordienko I.V., 2014. Fold systems of the Sayan-Baikal mountain area. In: Tectonics of Northern, Central and Eastern Asia. Explanatory note to the tectonic map of Northern-Central-Eastern Asia and adjacent areas. Scale 1:2500000. VSEGEI Printing House, Saint Petersburg, p. 53-59.

Bulgatov A.N., Klimuk B.C., Shivokhin E.A., 2010. Kulinda suite in the stratotype (Eastern Transbaikalia, MongoliaOkhotsk fold belt). Otechestvennaya Geologia (Russian Geology) (4), 54-60 (in Russian) [Булгатов А.Н., Климук В.C., Шивохин E.A. Кулиндинская свита в стратотипе (Восточное Забайкалье, Монголо-Охотский складчатый пояс) // Отечественная геология. 2010. № 4. С. 54-60].

Bussien D., Gombojav N., Winkler W., Von Quadt A., 2011. The Mongol-Okhotsk Belt in Mongolia - an appraisal of the geodynamic development by the study of sandstone provenance and detrital zircons. Tectonophysics 510 (1-2), 132-150. https://doi.org/10.1016/j.tecto.2011.06.024.

Dobretsov N.L., 1981. Global Petrological Processes. Nedra, Moscow, 236 p. (in Russian) [Добрецов Н.Л. Глобальные петрологические процессы. М.: Недра, 1981. 236 с.].

Dobretsov N.L., Korsakov L.P., Sklyarov E.V., 1988. Glaucophane schist belts of the Southern Siberia and the Amur region. Geologiya i Geofizika (Russian Geology and Geophysics) 29 (1), 3-11 (in Russian) [Добрещов Н.Л., Корса- 
ков Л.П., Скляров Е.В. Глаукофансланцевые пояса Южной Сибири и Приамурья // Геология и геофизика. 1988. T. 29. № 1. С. 3-11].

Dorjsuren B., Bujinlkham B., Minjin Ch., Tsukada K., 2006. Geological settings of the Ulaanbaatar terrane in the HangayHentey zone of the Devonian accretionary complex, Central Asian orogenic belt. In: Structural and tectonic correlation across the Central Asian orogenic collage: implications for continental growth and intracontinental deformation. Abstract and guidebook volume of Mongolian Workshop IGCP-480. Ulaanbaatar, p. 39-42.

Elbaev A.L., Gordienko I.V., Bayanova T.B., 2017. The U-Pb age of the rocks of the Hutul plagiodunite-troctolite-gabbro massif (Northern Mongolia). In: Proceedings of the IV All-Russia Youth Conference. Publishing House of the Buryatian State University, Ulan-Ude, p. 14-15 (in Russian) [Елбаев А.Л., Гордиенко И.В., Баянова Т.Б. U-Рb возраст пород Хутульского плагиодунит-троктолит-габбрового массива (Северная Монголия) // Материалы IV Всероссийской молодежной конференции. Улан-Удэ: Изд-во БГУ, 2017. С. 14-15].

Gordienko I.V., 1983. North-Khentei region. In: I.V. Luchitsky (Ed.), Continental volcanism of Mongolia. Nauka, Moscow, p. 55-67 (in Russian) [Гордиенко И.В. Северо-Хэнтейская область // Континентальный вулканизм Монголии / Ред. И.В. Лучицкий. М.: Наука, 1983. С. 55-67].

Gordienko I.V., 1987. Paleozoic Magmatism and Geodynamics of the Central Asian Fold Belt. Nauka, Moscow, 238 p. (in Russian) [Гордиенко И.В. Палеозойский магматизм и геодинамика Центрально-Азиатского складчатого пояса. М.: Наука, 1987. 238 с.].

Gordienko I.V., 1994. Paleozoic geodynamic evolution of the Mongol-Okhotsk fold belt. Journal of Southeast Asian Earth Sciences 9 (4), 429-433. https://doi.org/10.1016/0743-9547(94)90054-X.

Gordienko I.V., 1996. Correlation of pre-Jurassic sections of ancient continents and microcontinents in East Asia. Journal of Southeast Asian Earth Sciences 13 (3-5), 215-221. https://doi.org/10.1016/0743-9547(96)00028-1.

Gordienko I.V., 2006. Geodynamic evolution of late baikalides and paleozoids in the folded periphery of the Siberian craton. Geologiya i Geofizika (Russian Geology and Geophysics) 47 (1), 51-67.

Gordienko I.V., 2012. Fragments of the Ordovician and Devonian oceanic crust in the structures of the western part of the Mongolia-Okhotsk orogenic belt. In: Problems of geology and integrated development of natural resources of East Asia. The second All-Russia scientific conference. Institute of Geology and Natural Resources Management FEB RAS, Blagoveshchensk, p. 7-10 (in Russian) [Гордиенко И.В. Фрагменты ордовикской и девонской океанической коры в структурах западной части Монголо-Охотского орогенного пояса // Вопросы геологии и комплексного освоения природных ресурсов Восточной Азии: Вторая Всероссийская научная конференция. Благовещенск: ИГиП ДВО РАН, 2012. С. 7-10].

Gordienko I.V., 2014. Metallogeny of various geodynamic settings of the Mongolo-Transbaikalian region. Geology and Mineral Resources of Siberia (3s, Part 1), 7-13 (in Russian) [Гордиенко И.В. Металлогения различных геодинамических обстановок Монголо-Забайкальского региона // Геология и минерально-сырьевые ресурсы Сибири. 2014. № 3, часть 1. С. 7-13].

Gordienko I.V., Antonov A.Yu., Medvedev A.Ya., Orsoev D.A., Vetluzhskikh L.I., Badmatsyrenova R.A., Klimuk V.S., Elbaev A.L., Gorokhovsky D.V., 2012a. New data on magmatism and the geological structure of Central Transbaikalia. In: Geodynamic evolution of the lithosphere of the Central Asian mobile belt (from ocean to continent). Issue 10. IEC SB RAS, Irkutsk, Vol. 1, p. 60-62 (in Russian) [Гордиенко И.В., Антонов А.Ю., Медведев А.Я., Орсоев Д.А., Ветлужских Л.И., Бадмацыренова Р.А., Климук В.С., Елбаев А.Л., Гороховский Д.В. Новые данные по магматизму и геологическому строению Центрального Забайкалья // Геодинамическая эволюция литосферы Центрально-Азиатского подвижного пояса (от океана к континенту). Вып. 10. Иркутск: ИЗК СО РАН, 2012. Т. 1 C. 60-62].

Gordienko I.V., Medvedev A.Y., Gornova M.A., Tomurtogoo O., Goneger T.A., 2012b. The Haraa Gol terrane in the western Hentiyn Mountains (northern Mongolia): geochemistry, geochronology, and geodynamics. Russian Geology and Geophysics 53 (3), 281-292. https://doi.org/10.1016/j.rgg.2012.02.005.

Gordienko I.V., Medvedev A.Y., Tomuurtogoo O., 2010. Magmatism of the Kharagol terrain (Western Hentay, Mongolia). In: Geodynamic evolution of the lithosphere of the Central Asian mobile belt (from ocean to continent). Issue 8. IEC SB RAS, Irkutsk, Vol. 1, p. 72-73 (in Russian) [Гордиенко И.В., Медведев А.Я., Томууртогоо О. Магматизм Харагольского террейна (Западный Хэнтей, Монголия) // Геодинамическая эволюция литосферы ЦентральноАзиатского подвижного пояса (от океана к континенту). Вып. 8. Иркутск: ИЗК СО РАН, 2010. Т. 1. С. 72-73].

Gordienko I.V., Metelkin D.V., 2016. The evolution of the subduction zone magmatism on the Neoproterozoic and Early Paleozoic active margins of the Paleoasian Ocean. Russian Geology and Geophysics 57 (1), 69-81. https://doi.org/ 10.1016/j.rgg.2016.01.005.

Gordienko I.V., Minina O.R., Vetluzhskikh L.I., Elbaev A.L., Tomurtogoo O., Odgerel D., Ariunchimag Ya., 2017. KhenteiDauria active continental margin of the Mongolia-Okhotsk oceanic basin (sedimentation, magmatism, and geodynamic evolution). In: Geodynamic evolution of the lithosphere of the Central Asian mobile belt (from ocean to continent). Issue 15. IEC SB RAS, Irkutsk, p. 59-61 (in Russian) [Гордиенко И.В., Минина О.Р., Ветлужских Л.И., Елбаев А.Л., Томуртогоо О., Одгэрэл Д., Ариунчимэг Я. Хэнтей-Даурская активная континентальная окраина Монголо-Охотского океанического бассейна (осадконакопление, магматизм, геодинамическая эволюция) // Геодинамическая эволюция литосферы Центрально-Азиатского подвижного пояса (от океана к континенту). Вып. 15. Иркутск: ИЗК СО РАН, 2017. С. 59-61]. 
Gordienko I.V., Vetluzhskikh L.I., Mikhaltsov N.E., Kulakov E.V., 2018. New palaeomagnetic data from Argun terrane. Testing its association with Amuria and the Mongol-Okhotsk Ocean. Geophysical Journal International 213 (3), 1463-1477. https://doi.org/10.1093/gji/ggy057.

Gornova M.A., Almukhamedov A.I., Gordienko I.V., Kuz'min M.I., Medvedev A.Y., Tomurtogoo O., 2004. Adatsag ophiolitic complex (Northern Gobi, Mongolia) - fragment of the paleoastrocontaining system. In: Geodynamic evolution of the lithosphere of the Central Asian mobile belt (from ocean to continent). Issue 2. Publishing House of the Institute of Geography SB RAS, Irkutsk, Vol. 1, p. 98-101 (in Russian) [Горнова М.А., Альмухамедов А.И., Гордиенко И.В., Кузьмин М.И., Медведев А.Я., Томуртогоо О. Адацагский офиолитовый комплекс (Северная Гоби, Монголия) - фрагмент палеоостроводужной системы // Геодинамическая эволюция литосферы Центрально-Азиатского подвижного пояса (от океана к континенту). Вып. 2. Иркутск: Изд-во Института географии СО РАН, 2004. Т. 1. С. 98-101].

Gusev G.S., Khain V.E., 1995. On the ratio of the Baikal-Vitim, Aldan-Stanovoye and Mongolia-Okhotsk terrains (southern regions of Central Siberia). Geotektonika (Geotectonics) (5), 68-82 (in Russian) [Гусев Г.С., Хаин В.E. O соотношении Байкало-Витимского, Алдано-Станового и Монголо-Охотского террейнов (юг Средней Сибири) // Геотектоника. 1995. № 5. С. 68-82].

Kashiwagi K., Tsukada K., Minjin C., 2004. Paleozoic spherical radiolarians from the Gorkhi Formation, southwest Hentey range, central Mongolia; a preliminary report. Mongolian Geoscientist 24, 17-26.

Kelty T.K., An Yin, Batulzii Dash, Gehrels G.E., Ribeiro A.E., 2008. Detrital-zircon geochronology of Paleozoic sedimentary rocks in the Hangay-Hentey basin, North-Central Mongolia: Implications for the tectonic evolution of the MongolOkhotsk Ocean in Central Asia. Tectonophysics 451 (1-4), 290-311. https://doi.org/10.1016/j.tecto.2007.11.052.

Khanchuk A.I. (Ed.), 2006. Geodynamics, Magmatism and Metallogeny of the Eastern Regions of Russia. Book 1. Dal'nauka, Vladivostok, 572 p. (in Russian) [Геодинамика, магматизм и металлогения востока России / Ред. А.И. Ханчук. Владивосток: Дальнаука, 2006. Кн. 1. 572 с.].

Khanchuk A.I., Didenko A.N., Popeko L.I., Sorokin A.A., Shevchenko B.F., 2015. Structure and evolution of the MongolOkhotsk Orogenic Belt. In: A. Kröner (Ed.), The Central Asian Orogenic Belt: geology, evolution, tectonics, and models. Beiträge zur Regionalen Geologie der Erde, vol. 32, p. 211-234.

Kotlyar G.V., Popeko L.I., 1974. Carboniferous deposits of the Transbaikalia. In: L.I. Krasny, L.I. Popeko (Eds.), Paleozoic of the Far East. Institute of Tectonics and Geophysics, Far East Branch of the USSR Acad. Sci., Khabarovsk, p. 140-158 (in Russian) [Котляр Г.В., Попеко Л.И. Каменноугольные отложения Забайкалья // Палеозой Дальнего Востока / Ред. Л.И. Красный, Л.И. Попеко. Хабаровск: ИТиГ ДВНЦ АН СССР, 1974. С. 140-158].

Kravchinsky V.A., Cogné J.P., Harbert W.P., Kuzmin M.I., 2002. Evolution of the Mongol-Okhotsk Ocean as constrained by new palaeomagnetic data from the Mongol-Okhotsk suture zone, Siberia. Geophysical Journal International 148 (1), 34-57. https://doi.org/10.1046/j.1365-246x.2002.01557.x.

Kurihara T., Tsukada K., Otoh S., Kashivagi K., Minjin Ch., Sersmaa G., Dorjsuren B., Bujinlkham B., 2006. Middle Paleozoic radiolarians from the Gorkhi formation, Central Mongolia. In: Structural and tectonic correlation across the Central Asian Orogenic Collage: implications for continental growth and intracontinental deformation. Abstract and guidebook volume of Mongolian Workshop IGCP-480. Ulaanbaatar, p. 67.

Kurilenko A.V., Yadrishchenskaya N.G., Neberikutina L.N., 2015. Stages of sedimentation of the Silurian-Devonian deposits of the Aga zone of the Eastern Transbaikalia. In: Modern problems of paleontology. Materials of the LXI session of the Paleontological Society. VSEGEI Publishing House, Saint Petersburg, p. 62-64 (in Russian) [Куриленко А.В., Ядрищенская Н.Г., Неберикутина Л.Н. Этапы осадконакопления силурийско-девонских отложений Агинской зоны Восточного Забайкалья // Современные проблемы палеонтологии: Материалы LXI сессии Палеонтологического общества. СПб.: Изд-во ВСЕГЕИ, 2015. С. 62-64].

Kuzmin M.I., Filippova I.B., 1979. The history of development of the Mongolia-Okhotsk belt in the Middle Late Paleozoic and Mesozoic. In: L.P. Zonenshain, O.G. Sorokhtin (Eds.), The structure of lithospheric plates. Institute of Oceanology of the USSR Acad. Sci., Moscow, p. 189-226 (in Russian) [Кузьмин М.И., Филиппова И.Б. История развития Монголо-Охотского пояса в среднем - позднем палеозое и мезозое // Строение литосферных плит / Ред. Л.П. Зоненштайн. О.Г. Сорохтин. М.: Институт океанологии АН СССР, 1979. С. 189-226].

Marinov N.A. (Ed.), 1973a. Geology of the Mongolian People's Republic. Vol. I. Nedra, Moscow, 584 p. (in Russian) [Геология Монгольской Народной Республики / Ред. Н.А. Маринов. М.: Недра, 1973. Т. I. 584 с.

Marinov N.A. (Ed.), 1973b. Geology of the Mongolian People's Republic. Vol. II. Nedra, Moscow, 752 p. (in Russian) [Геология Монгольской Народной Республики / Ред. Н.А. Маринов. М.: Недра, 1973. Т. II. 752 с.].

Medvedev A.Y., Bulgatov A.N., Gornova M.A., Gordienko I.V., Al'mukhamedov A.I., 2007. Metavolcanites from Kyran block (Eastern Transbaikalia). Litosfera (Lithosphere) (1), 138-146 (in Russian) [Медведев А.Я., Булгатов А.Н., Горнова М.А., Гордиенко И.В., Альмухамедов А.И. Метавулканиты Кыранского блока (Восточное Забайкалье) // Литосфера. 2007. № 1. С. 138-146].

Minina O.R., Ariunchimeg Y., Gordienko I.V., Vetluzhskikh L.I., 2016a. New data on the age of the Paleozoic deposits of the Hangai-Hentei megazone of the Northern Mongolia. In: Geodynamic evolution of the lithosphere of the Central Asian mobile belt (from ocean to continent). Issue 14. IEC SB RAS, Irkutsk, p. 199-201 (in Russian) [Минина O.P., Ариунчимэг Я., Гордиенко И.В., Ветлужских Л.И. Новые данные о возрасте палеозойских отложений Хангай- 
Хэнтейской мегазоны Северной Монголии // Геодинамическая эволюция литосферы Центрально-Азиатского складчатого пояса (от океана к континенту). Вып. 14. Иркутск: ИЗК СО РАН, 2016. С. 199-201].

Minina O.R., Kurilenko A.V., Ariunchimeg Y., Naugolnykh S.V., Vetluzhskikh L.I., 2016b. New data on the age of the Carboniferous deposits of the Hangai-Hentei megazone of the Northern Mongolia. In: The 70th anniversary of Mongolian paleontolocial expedition of Academy of Sciences, USSR. International Symposium Abstract Volume. Institute of Paleontology and Geology, Ulaanbaatar, p. 54-55 (in Russian) [Минина О.Р., Куриленко А.В., Ариунчимэг Я., Наугольных С.В., Ветлужских Л.И. Новые данные о возрасте каменноугольных отложений Хангай-Хэнтейской мегазоны Северной Монголии // The 70th Anniversary of Mongolian Paleontolocial Expedition of Academy of Sciences, USSR. International Symposium Abstract Volume. Institute of Paleontology and Geology, Ulaanbaatar, 2016. C. 54-55].

Minina O.R., Kurilenko A.V., Ariunchimeg Y., Vetluzhskikh L.I., Naugolnych S.V., 2017. New data on the age of deposits of the Khentey series (Khangay-Khentey megazone, Northern Mongolia). In: Kazan Golovkinsky stratigraphic meeting 2017 abstract volume. KFU, Kazan, p. 130-132.

Mullen E.D., 1983. $\mathrm{MnO} \mathrm{TiO}_{2} / \mathrm{P}_{2} \mathrm{O}_{5}$ : a minor element discriminant for basaltic rocks of oceanic environments and its implications for petrogenesis. Earth and Planetary Science Letters 62 (1), 53-62. https://doi.org/10.1016/0012821X(83)90070-5.

Nokleberg W.J., Parfenov L.M., Monger J.W.H., Baranov B.B., Byalobzhesky S.G., Bundtzen T.K., Feeney T.D., Fujita K., Gordey S.P., Grantz A., Khanchuk A.I., Natal'in B.A., Natapov L.M., Norton I.O., Patton W.W. Jr., Plafker G., Scholl D.W., Sokolov S.D., Sosunov G.M., Stone D.B., Tabor R.W., Tsukanov N.V., Vallier T.L., Wakita K., 1994. Circum-North Pacific Tectonostratigraphic Terrane Map. US Geological Survey Open-File Report 94-714. New York, 221 p. https:// doi.org/10.3133/ofr94714.

Parfenov L.M., Nokleberg W.J., Khanchuk A.I., 1998. Principles of compilation and main subdivisions of the legend for the geodynamic map of North and Central Asia, the southern regions of the Russian Far East, Korea and Japan. Tikhookeanskaya Geologiya 17 (3), 3-13 (in Russian) [Парфенов Л.М., Ноклеберг У.Дж., Ханчук А.И. Принципы составления и главные подразделения легенды геодинамической карты Северной и Центральной Азии, юга российского Дальнего Востока, Кореи и Японии // Тихоокеанская геология. 1998. Т. 17. № 3. С. 3-13].

Parfenov L.M., Popeko L.I., Tomurtogoo O., 1999. Problems of tectonics of the Mongolia-Okhotsk orogenic belt. Tikhookeanskaya Geologiya 18 (5), 24-43 (in Russian) [Парфёнов Л.М., Попеко Л.И., Томуртогоо О. Проблемы тектоники Монголо-Охотского орогенного пояса // Тихоокеанская геология. 1999. Т. 18. № 5. С. 24-43].

Peive A.V., Yanshin A.L., Zonenshain L.P. et al., 1976. Formation of the continental crust of Northern Eurasia (in connection with the compilation of a new tectonic map). Geotektonika (Geotectonics) (5), 6-23 (in Russian) [Пейве A.В., Яншин А.Л., Зоненшайн Л.П. и др. Становление континентальной земной коры Северной Евразии (в связи с составлением новой тектонической карты) // Геотектоника. 1976. № 5. С. 6-23].

Petrov O.V., Leonov Yu.G., Tingdong L., Tomurtogoo O. (Eds.), 2014. Tectonics of Northern, Central and Eastern Asia. Explanatory Note to the Tectonic Map of Nortern-Central-Eastern Asia and Adjacent Areas. Scale 1:2500000. VSEGEI Printing House, Saint Petersburg, $192 \mathrm{p}$.

Ruppen D., Knaf A., Bussien D., Winkler W., Chimedtseren A., Quadt A., 2014. Restoring the Silurian to Carboniferous northern active continental margin of the Mongol-Okhotsk Ocean in Mongolia: Hangay-Hentey accretionary wedge and seamount collision. Gondwana Research 25 (4), 1517-1534. https://doi.org/10.1016/j.gr.2013.05.022.

Rutshtein I.G., Starchenko V.V. (Eds.), 1979. Geological Map of the Chita Region. Scale 1:500000. The USSR Ministry of Geology, Moscow (in Russian) [Геологическая карта Читинской области. Масштаб 1:500000 / Ред. И.Г. Рутштейн, В.В. Старченко. М.: Министерство геологии СССР, 1979].

Ruzhentsev S.V., Minina O.R., Nekrasov G.E., Aristov V.A., Golionko B.G., Doronina N.A., Lykhin D.A., 2012. The Baikal-Vitim fold system: structure and geodynamic evolution. Geotectonics 46 (2), 87-110. https://doi.org/10.1134/ S0016852112020033.

Ruzhentsev S.V., Nekrasov G.E., 2009. Tectonics of the Aga zone, Mongolia-Okhotsk belt. Geotectonics 43 (1), 34-50. https://doi.org/10.1134/S0016852109010038.

Şengör A.M.C., Natal'in B.A., Burtman V.S., 1993. Evolution of the Altaid tectonic collage and Paleozoic crustal growth in Eurasia. Nature 364 (6435), 299-307. https://doi.org/10.1038/364299a0.

Shivokhin E.A., Ozersky A.F., Artamonova N.A., Dukhovsky A.A., Karasev V.V., Kurilenko A.V., Nadezhdina T.N., Pavlenko Y.V., Raitina N.I., Shor G.M., 2010. State Geological Map of the Russian Federation. Scale 1:1000000 (third generation). Sheet M-50 - Borzya. Explanatory note. VSEGEI Cartographic Factory, Saint Petersburg, 553 p. (in Russian) [Шuвохин Е.А., Озерский А.Ф., Артамонова Н.А., Духовский А.А., Карасев В.В., Куриленко А.В., Надеждина Т.Н., Павленко Ю.В., Раитина Н.И., Шор Г.М. Государственная геологическая карта Российской Федерации. Масштаб 1:1000000 (третье поколение). Лист М-50 - Борзя. Объяснительная записка. СПб.: Картографическая фабрика ВСЕГЕИ, 2010. 553 с.].

Sizova P.P., 1935. To the Description of the Sections of the Lower Carboniferous Deposits of the Urmuktei Mountain Area and the Khaptagai Mountains in Mongolia. Proceedings of the Mongolian Commission of the USSR Acad. Sci. No. 15. 14 p. (in Russian) [Сизова П.П. К характеристике разрезов нижнекарбоновых отложений района горы Урмуктэй и гор Хаптагай в Монголии. Труды Монгольской комиссии АН СССР. 1935. № 15. 14 с.]. 
Sklyarov E.V., Mazukabzov A.M., Donskaya T.V., Doronina N.A., Shafeev A.A., 1994. The complex of the metamorphic core of the Zagan ridge (Transbaikalia). Doklady AN 339 (1), 83-86 (in Russian) [Скляров Е.В., Мазукабзов А.М., Донская T.В., Доронина Н.А., Шафеев А.А. Комплекс метаморфического ядра Заганского хребта (Забайкалье) // Доклады АН. 1994. Т. 339. № 1. С. 83-86].

Sorokin A.A., Kudryashov N.M., 2015. The first U-Pb geochronological and geochemical data on Late Vendian and Early Paleozoic acid volcanic rocks of the Mamyn Terrane (Central Asian Fold Belt). Doklady Earth Sciences 465 (2), 1237-1242. https://doi.org/10.1134/S1028334X15120077.

Sorokin A.A., Kudryashov N.M., 2017. The Cambrian-Ordovician diorite-granodiorite-granite association of the Mamyn Terrane (Central Asian Fold Belt): U-Pb geochronological and geochemical data. Doklady Earth Sciences 472 (1), 113-118. https://doi.org/10.1134/S1028334X17010275.

Sorokin A.A., Smirnova Y.N., Kotov A.B., Kovach V.P., Sal'nikova E.B., Popeko L.I., 2015. Provenances of the paleozoic terrigenous sequences of the Oldoi terrane of the Central Asian orogenic belt: Sm-Nd isotope geochemistry and U-Pb geochronology (LA-ICP-MS). Geochemistry International 53 (6), 534-544. https://doi.org/10.1134/S001670291 5040072 .

Sun S.S., McDonough W.E., 1989. Chemical and isotopic systematics of oceanic basalts: implications for mantle composition and processes. In: A.D. Sanders, M.J. Norry (Eds.), Magmatism in the oceanic basins. Geological Society, London, Special Publications, vol. 42, p. 313-345. https://doi.org/10.1144/gsl.sp.1989.042.01.19.

Tamura Y., Tani K., Ishizuka O., Chang Q., Shukuno H., Fiske R.S., 2005. Are arc basalts dry, wet, or both? Evidence from the Sumisu caldera volcano, Izu-Bonin arc, Japan. Journal of Petrology 46 (9), 1769-1803. https://doi.org/ 10.1093 /petrology/egi033.

Tomurtogoo O., 2005. Tectonics and structural evolution of Mongolia. In: SEG-IAGOD Field Trip (14-16 August, 2005). 8 Bieninal SGA Meeting IAGOD Guidebook Series, vol. 11. London, p. 5-12.

Tomurtogoo O., 2014. Tectonics of Mongolia. In: O.V. Petrov, Yu.G. Leonov, L. Tingdong, O. Tomurtogoo (Eds.), Tectonics of Northern, Central and Eastern Asia. Explanatory Note to the Tectonic Map of Northern-Central-Eastern Asia and adjacent areas. Scale 1:2500000. VSEGEI Printing House, Saint Petersburg, p. 110-126.

Tomurtogoo O., Windley B.F., Kröner A., Badarch G., Liu D.Y., 2005. Zircon age and occurrence of the Adaatsag ophiolite and Muron shear zone, Central Mongolia: constraints on the evolution of the Mongol-Okhotsk ocean, suture and orogen. Journal of the Geological Society 162 (1), 125-134. https://doi.org/10.1144/0016-764903-146.

Tsygankov A.A., Burmakina G.N., Khubanov V.B., Buyantuev M.D., 2017. Geodynamics of Late Paleozoic batholithforming processes in western Transbaikalia. Petrology 25 (4), 396-418. https://doi.org/10.1134/S0869591117 030043.

Voznesenskaya T.A., 1998. Nature of the Caledonian Khentei basin, Mongolia. Lithology and Mineral Resources 33 (4), 369-379.

Yanshin A.L. (Ed.), 1974. Tectonics of the Mongolian People's Republic. Nauka, Moscow, 284 p. (in Russian) [Тектоника Монгольской Народной Республики / Ред. А.Л. Яншин. М.: Наука, 1974. 284 с.].

Yanshin A.L. (Ed.), 1989. Map of Geological Formations of the Mongolian People's Republic. Scale 1:1500000. Novosibirsk Cartographic Factory, the USSR State Department of Geology and Cartography, Novosibirsk (in Russian) [Карта геологических формаций Монгольской Народной Республики. Масштаб 1:1500000 / Ред. А.Л. Яншин. Новосибирск: Новосибирская картографическая фабрика, ГУГК СССР, 1989].

Yarmolyuk V.V., Kozlovsky A.M., Sal'nikova E.B., Kozakov I.K., Kotov A.B., Lebedev V.I., Eenjin G., 2013. Age of the Khangai batholith and challenge of polychronic batholith formation in Central Asia. Doklady Earth Sciences 452 (2), 1001-1007. https://doi.org/10.1134/S1028334X13100176.

Zonenshain L.L., Kuz'min M.I., Moralev V.M., 1976. Global Tectonics, Magmatism and Metallogeny. Nedra, Moscow, 232 p. (in Russian) [Зоненшайн Л.Л., Кузьмин М.И., Моралев В.М. Глобальная тектоника, магматизм и металлогения. М.: Недра, 1976. 232 с.].

Zonenshayn L.P., Kuz'min M.I., Natapov L.M., 1990. Tectonics of the Lithospheric Plates of the USSR Territory. Nedra, Moscow, Vol. 2, 327 p. (in Russian) [Зоненшайн Л.П., Кузьмин М.И., Натапов Л.М. Тектоника литосферных плит территории СССР. М.: Недра, 1990. Т. 2. 327 с.].

Zorin Y.A., Belichenko V.G., Rutshtein I.G., Zorina L.D., Spiridonov A.M., 1998. Geodynamics of the western part of the Mongolo-Okhotsk fold belt and tectonic position of gold manifestations in ores in Transbaikalia. Geologiya $i$ Geofizika (Russian Geology and Geophysics) 39 (11), 1578-1586.

Zorin Y.A., Belichenko V.G., Turutanov E.Kh., Mazukabzov A.M., Sklyarov E.V., Mordvinova V.V., 1997. The structure of the Earth's crust and geodynamics of the Baikal folded region. Otechestvennaya Geologiya (Russian Geology) (10), 37-44 (in Russian) [Зорин Ю.А., Беличенко В.Г., Турутанов Е.Х., Мазукабзов А.М., Скляров Е.В., Мордвинова В.В. Строение земной коры и геодинамика Байкальской складчатой области // Отечественная геология. 1997. № 10. С. 37-44].

Zorin Y.A., Sklyarov E.V., Belichenko V.G., Mazukabzov A.M., 2009. Island arc-back-arc basin evolution: implications for Late Riphean - Early Paleozoic geodynamic history of the Sayan-Baikal folded area. Russian Geology and Geophysics 50 (3), 149-161. https://doi.org/10.1016/j.rgg.2008.06.022. 

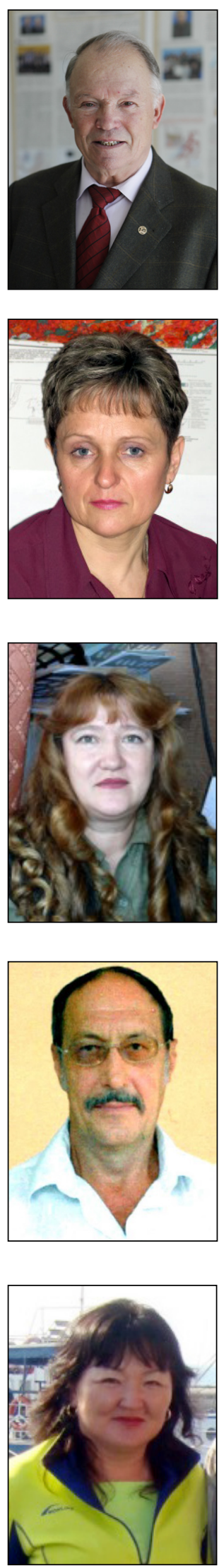

Иван Власович Гордиенко, докт. геол.-мин. наук, член-корреспондент РАН, советник РАН, г.н.с. Геологический институт СО РАН

670047, Улан-Удэ, ул. Сахьяновой, 6а, Россия

$\triangle$ e-mail: gord@pres.bscnet.ru

ORCID ID https://orcid.org/0000-0002-2890-1105

Ivan V. Gordienko, Doctor of Geology and Mineralogy, Corresponding Member of the RAS,

Counsellor of the RAS, Chief Researcher

Geological Institute, Siberian Branch of RAS

6a Sakhyanova street, Ulan-Ude 670047, Russia

Ольга Романовна Минина, докт. геол.-мин. наук, зав. лабораторией

Геологический институт СО РАН

670047, Улан-Удэ, ул. Сахьяновой, 6а, Россия

e-mail: yaksha@rambler.ru

Olga R. Minina, Doctor of Geology and Mineralogy, Head of Laboratory

Geological Institute, Siberian Branch of RAS

6a Sakhyanova street, Ulan-Ude 670047, Russia

Лариса Ивановна Ветлужских, канд. геол.-мин. наук, с.н.с.

Геологический институт СО РАН

670047, Улан-Удэ, ул. Сахьяновой, 6а, Россия

e-mail: L_vetla@mail.ru

Larisa I. Vetluzhskikh, Candidate of Geology and Mineralogy, Senior Researcher Geological Institute, Siberian Branch of RAS

6a Sakhyanova street, Ulan-Ude 670047, Russia

Александр Яковлевич Медведев, докт. геол.-мин. наук, г.н.с.

Институт геохимии им. А.П. Виноградова СО РАН

664033, Иркутск, ул. Фаворского, 1А, Россия

e-mail: amedv@igc.irk.ru

Aleksander Ya. Medvedev, Doctor of Geology and Mineralogy, Chief Researcher

A.P. Vinogradov Institute of Geochemistry, Siberian Branch of RAS

1A Favorsky street, Irkutsk 664033, Russia

Дашдориджгохо Одгэрэл, канд. геол.-мин. наук, руководитель Отделения геологии Институт палеонтологии и геологии МАН

210351, Улан-Батор, ПО. Бокс 118, Монголия

e-mail: odgerel.dashdorjgochoo@gmail.com

Dashdorjgochoo Odgerel, Candidate of Geology and Mineralogy, Head of Geology Department Institute of Paleontology and Geology of MAS

PO. Box 118, Ulaanbaatar 210351, Mongolia 